\title{
Joints and Ligaments of Hind-Limbs of the European Bison in Its Postnatal Development
}

\author{
Franciszek KOBRYŃCZUK
}

Kobryńczuk F., 1976: Joints and ligaments of hind-limbs of the European bison in its postnatal development. Acta theriol., 21, 4: 37-100. [With 16 Tables \& 32 Figs.]

Using material of the hind-limbs of 119 European bison (Bison bonasus Li n n a e s, 1758) (74 males, 45 females) the author studied the joints in course of postnatal development. When the opportunity occurred, the observations were also made for comparative purposes on other species of Bovinae. The capacity of articular cavities and linear measurements of ligaments, articular cartilages, menisci and articular surfaces were measured. The angles of the curvature of the articular surfaces and the range of movements for flexion and extension of joints (except sacroiliac and hip joints) were also estimated. The results concerning the dimension of articular surfaces and menisci and the capacity of the acetabulum were analysed statistically for groups, consisting of more than 4 specimens.

[Inst. Animal Physiol., Agric. Acad., 03-849 Warszawa, Grochowska 272, Poland]

I. Introduction

II. Material and method

III. Own observations

1. Joints of the pelvic girdie

1.1. Pelvic symphysis

1.2. Sacroiliac joint

1.3. Obturator membrane

3. Stifle joint

3.1. Femorotibial joint

3.2. Femoropatellar joint

4. Fibrous band of leg

5. Hock joint

6. Metatarsophalangeal joints

7. Proximal interphalangeal joints

8. Distal interphalageal joints

9. Joints of accessory digits $I \dot{I}$ and $\dot{V}$

IV. Discussion

References

Streszczenie

\section{INTRODUCTION}

From among the studies on the structure of joints in the European bison K r y sia k's (1951) paper concerning the morphology of the nuchal ligament should be mentioned here. Em pel (1962) published a study 
on the suturae between the bones of the skull of this animal and W egrzy $\mathrm{n}$ \& S e r watk a (1961) their detailed observations on the sacrosciatic ligament in the European bison and domestic cattle. $\mathrm{R}$ a d o m s ki (1972) investigated the structure of the joints and ligaments of the forelimbs of the bison in its postnatal development on rich materials. Taking the opportunity of their osteological studies, W roblew ski (1927), Koc h (1932), Poleiner (1932), J anicki (1938), J uśko (1953), Empel \& Roskos z (1963), Sokolov (1972) and Kobryń (1973) made detached observation on the articulations of bones. In discussing the volume of the autopodial bones in the European bison, K obryn$\mathrm{czuk} \& \mathrm{~K}$ obry ń (1973) provided remarks useful for the subject concerned and $\mathbf{S} w$ i e ż y ński (1962) gave a short morphological description of the middle interosseous muscle of this animal. Pilarski \& Ros$\mathrm{kosz}$ (1957) studied the problem of the ankylosis of the lumbosacral joint in the process of sacralization of the last lumbar vertebra in the European bison and Radomski \& Kobryn (1969) described a case of the dislocation of the shoulder joint. A case of the occurrence of a pseudoarthrosis in the cervical vertebrae has been reported by $\mathrm{K}$ ob r y n \& K obryńc z u k (1973).

The lack of a systematic study of the joints in the hind-limbs of the European bison in the course of postnatal development has induced the author to take up this problem.

\section{MATERIAL AND METHOD}

The present study was carried out on the hind-limbs of 71 European bisons, 47 males and 24 females. Further observations of articular surfaces were made on the skeletons of 48 European bisons (27 males and 21 females) belonging to the collection of the European Bison Anatomical Research Centre, Agricultural Acade$\mathrm{my}$, in Warsaw. The carcasses of animals were obtained from breeding stations and zoological gardens of this country. The age of specimens was established on the basis of the European Bison Pedigree Book (Źabinski, 1947-1965; Ż a biński \& Raczynski, 1972). The division of the material into age groups, separately for either sex, is given in Table 1.

When the opportunity occurred, detached observations were also made for comparative purposes on other species of the Bovinae, like Bison bison L., Bison bonasus-Bison bison hybrids, Bison bonasus-domestic cattle hybrids, domestic cattle, Watussi cattle, buffaloes, zebus and yaks. This material is presented in Table 1, the age of the European bison-domestic cattle hybrids being given after Pytel $\& \mathrm{Krasinska}$ (1971). The domestic cattle and other species derived from zoological gardens were considered to be adult on the basis of the state of ossification of the epiphyseal cartilages. Measurements of the capacity of articular cavities were made on fresh carcasses by injecting them with warm gelatin colloid by $\mathrm{K}$ ostyra's (1962) method. This made it possible to get to know the shape of the articular cavities and their communications, if there were any, with the neighbouring synovial bursae. Linear measurements (to an accuracy of 0.1 or $1.0 \mathrm{~mm}$ ) of ligaments, articular cartilages, menisci, articular surfaces, etc. were mäle on dissect- 
ed carcasses, fixed by the method of Pilarski et al. (1967). Fresh preparations of the limbs, separated from the whole of body were fixed in a $4 \%$ solution of formalin. The volume of the menisci (in cu. $\mathrm{cm}$ ) was measured by immersing them in a liquid in a graduated measuring-glass. The capacity of the acetabulum of the hip bone was determined by filling it with shot, after its rim had been evened

\section{Table 1}

Material.

$\mathrm{n}$ - in all examinations; $\mathrm{n}_{1}$ - only in examinations of articular surfaces; $n_{2}$ - in all examinations of articular surfaces, 1 - for specimens used in all examinations, 2 - for specimens used in examinations of articular surfaces.

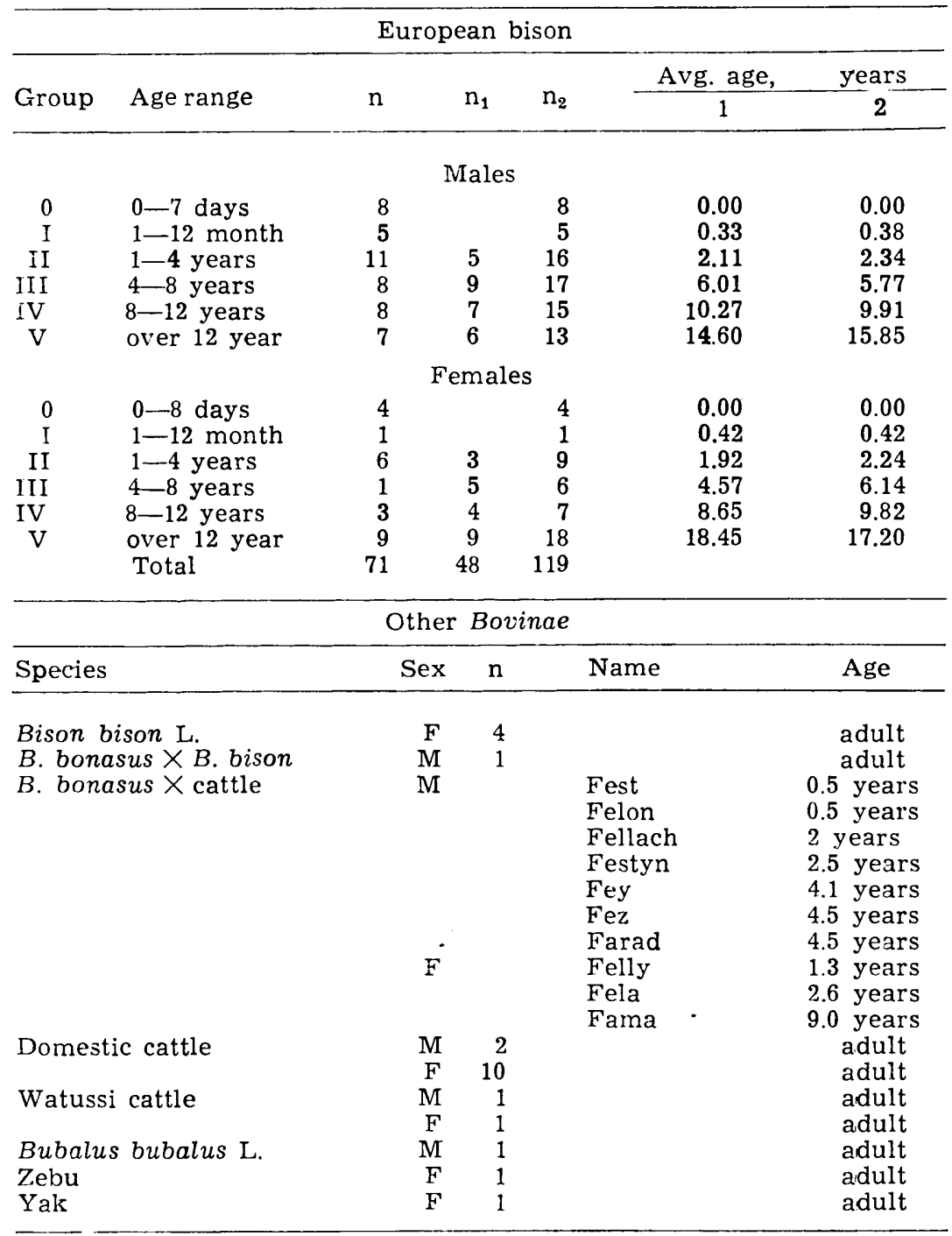


with plasticine. For measuring its thickness, the articular cartilage was removed by making a cut with a scalpel along a chord of the articular surface.

Auxiliary angles of the curvature of articular surfaces were measured in sagittal planes on carcasses and digested skeletons from museum collections. Although the shape of articular surfaces corresponds only in approximation with geometrical figures, it proves helpful to represent them for comparison as regular solids. This procedure was recommended and adopted, among other workers, by D u e r s t (1926), Poplewski (1927), Vokken et al. (1961) and Kosty a (1962). Here, such studies have been carried out only for joints with articular surfaces described more or less on the same radius. In the European bison these articular surface include the trochlea and condyles of the femur and the surfaces of the tarsocrural, proximal intertarsal and metatarsophalangeal joints.

In order to determine the auxiliary angle $(\alpha)$ of the sagittal curvature of an articular surface, the length of the chord $a(B C)$ was measured (Fig. 1 - an example of the calculation of this curvature in the metatarsophalangeal joint), then a point $A$ was chosen so that it was approximately the highest point of the arc in relation to its chord $B C$, and the lines $A B$ and $A C$ were measured (auxiliary measurements). The use of trigonometrical formulae for the triangle $A B C$ with sides $a, b$ and $c$ made it possible to work out the value of the auxiliary angle $\beta_{1}$. Then, it was easy to fix the angles $\alpha_{1}$ and $\alpha$. The following working formula is used to calculate the angle

$$
\cos \alpha / 2=\left(a^{2}-b^{2}-c^{2}\right) / \pm 2 b c
$$

The value obtained for the angle $\alpha$ should be marked in the appropriate quarter of the rectangle of coordinates.

Then, the angle $\alpha$ being known, the radius of curvature $(r)$ was calculated from the equation

$$
r=a /(2 \sin \alpha / 2)
$$

The angle $\beta$ of a concave articular surface (Fig. 1 shows as an example the proximal articular surface of the proximal phalanx) was obtained from the equation

$$
\sin \beta / 2=1 / a(\sin \alpha / 2)
$$

where $l$ is the chord $(D E)$ of the concave articular surface, the other symbols being the same as previously.

The range of movements for the flexion and extension of the tarsocrural, proximal intertarsal and metatarsophalangeal joints was calculated by subtracting the values of the angles of the adjoining articular surfaces from each other:

$$
\begin{array}{ll}
\varphi=\alpha-\beta & \text { when } \alpha>\beta \\
\varphi=\beta-\alpha & \text { when } \alpha<\beta
\end{array}
$$

The ridges of the trochlea of the femur lie in the planes which form a dihedral angle $\alpha$ below the knee. This angle was calculated from the formula

$$
\operatorname{tg} \alpha / 2=(b-c) / 2 a
$$

where $a$ is the length of the chord of the lateral ridge of the trochlea, and $b$ and $c$ are the proximal and distal widths of the trochlea.

The trochlea of the femur is inclined to a side, forming an angle $\alpha$ with the plane parallel to the long axis of the femur and passing through the backmost points of the condyles of this bone. The equation used to calculate this angle was

$$
\operatorname{tg} \alpha=c /(a-b)
$$

The lengths of the lines $a, b$ and $c$ were obtained with the help of a special table, designed by Empe 1 \& R os k os z (1963) and illustrated diagrammatically in Fig. 7.

The angles of inclination of such elements as the head and condyles 0 the femur 
and the trochleae of $\mathrm{Mt} I I I+I \mathrm{~V}$ in relation to the long axis of the bone were determined trigonometrically as angles of suitably chosen triangles.

The angles formed in the sagittal plan by the long bones meeting in the joints were determined in a similar way. About 100 photographs of European bisons in side view were used for this purpose. The prominences of the skeleton and central points of the joints manifesting themselves through the skin served as measuring points. The coxofemoral, femorotibial and tibiometatarsal angles were measured by this method. The accuracy of measurements is given in decimals of a degree.

The results concerning all the dimensions of articular surfaces and menisci and the capacity of the acetabulum were analysed statistically ( $s$ and $v$ ) for groups

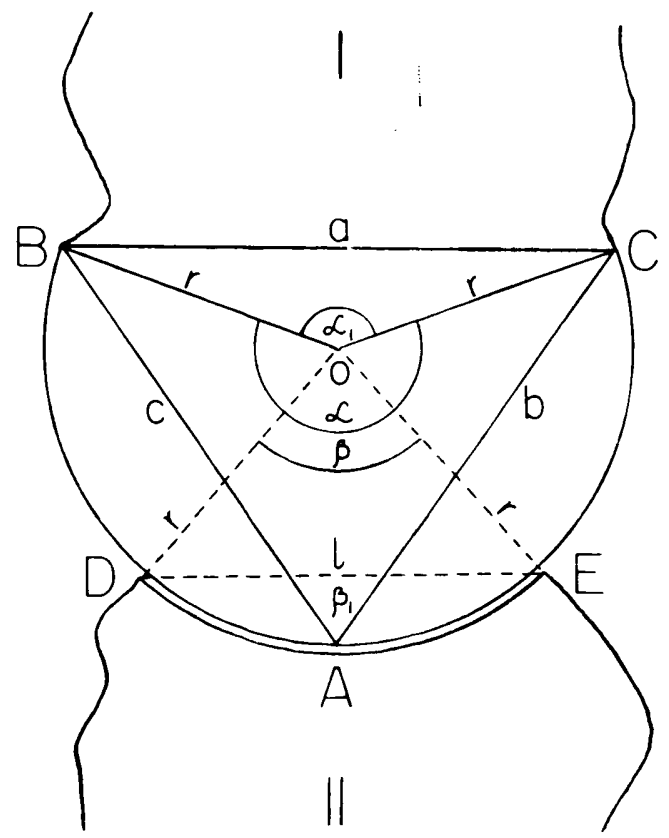

Fig. 1. Determination of the angle of convex and concave curvatures of an articular surface exemplified by the metatarsophalangeal joint.

$\alpha \downarrow-$ angle of curvature of the trochlea of $M t I I I+I V, \beta-$ angle of curvature of the proximal articular surface of the proximal phalanx, $r$ - radius of curvature of trochlea and articular surface of the proximal phalanx, $\alpha_{1}, \beta_{1}-$ central angle and angle inscribed in a circle with the centre $0, a(B C)-$ chord of trochlea, $l$ (DE) - chord of articular surface of proximal phalanx, I - bones of $M t I I I+I V$, II - proximal phalanx.

consisting of more than 4 specimens. This procedure was not applied for the dimensions of ligaments, since the data obtained, under different conditions of preparation, for these structures, readily undergoing decay, were approximate.

The growth coefficient is, according do Davletova (1960), the quotient of measurements in groups $\mathrm{V}$ and 0 . Bisons belonging to groups III, IV and $\mathrm{V}$ are regarded as adult specimens. The Latin nomenclature is based on the Nomina Anatomica Veterinaria (1973), on text-books by Poplewski (1948), Ellenberger \& Baum (1943), Martin \& Schauder (1938) and papers by Nickel \& *anger (1953) and Kostyra (1962). 


\section{OWN OBSERVATIONS}

\section{Joints of the Pelvic Girdle}

\subsection{Pelvic Symphysis}

The fibrocartilage of the pelvic symphysis forms two centres, of which the anterior (Fig. 2-1) unites the pubic bones and the posterior (Fig. 2-2) the ischia of the opposite sides. The two centres are connected by a narrow isthmus of the same tissue. In the youngest Euro-

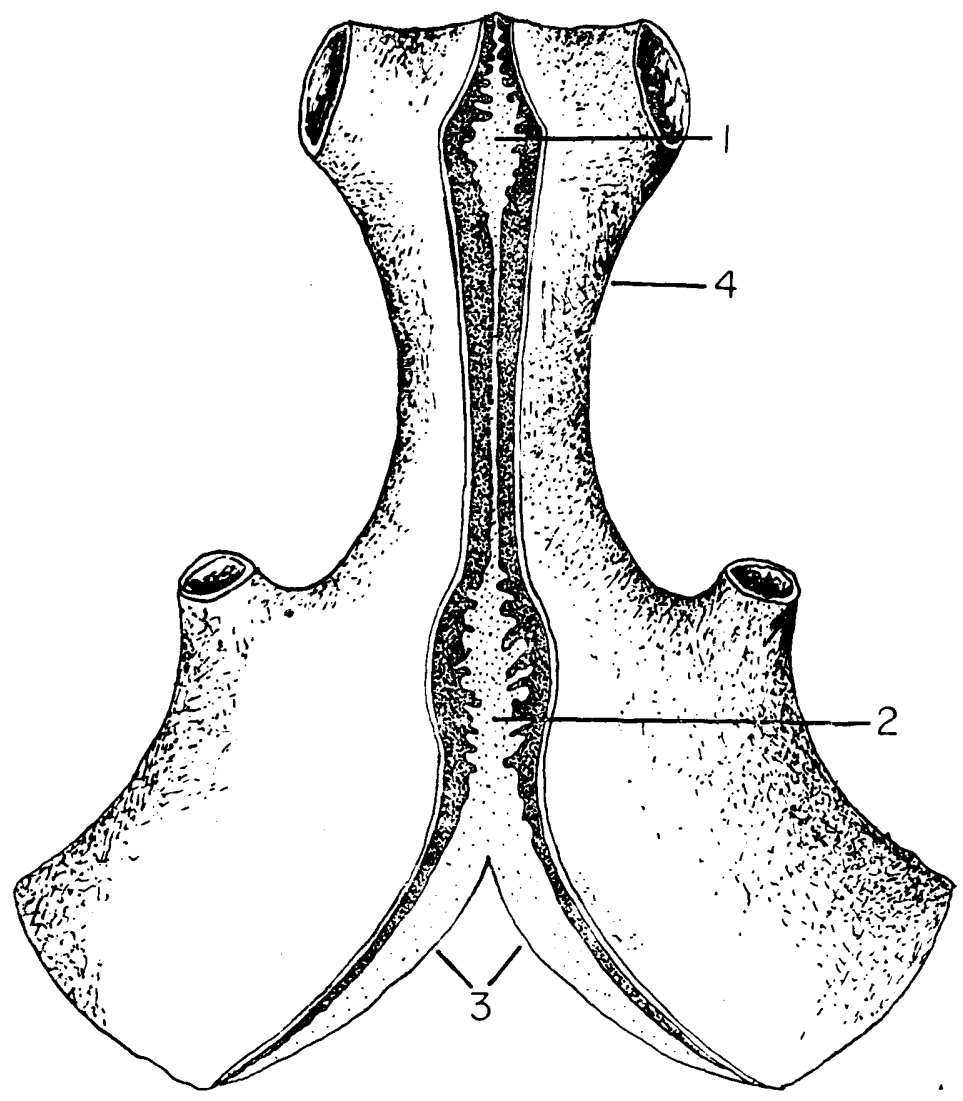

Fig. 2. Horizontal section through pelvic symphysis (16-month-old male).

1,2 - anterior and posterior cartilaginous centres, 3 - ischiatic arch, 4 - edge of the obturator foramen.

pean bisons the symphyseal fibrocartilage passes into the epiphyseal cartilage of the ischial tuberosity and forms the cartilaginous bordering of the ischiatic arch (Fig. 2-3). A small number of fibres run transversely on the dorsal surface of the symphysis, their number being 
greater on the ventral side; they meet in the midline to form a high fibrous crest. In the anterior portion of the symphysis these fibres extend obliquely cephalad and in the posterior portion obliquely caudad.

The pelvic symphysis is strengthened anteriorly by the anterior pubic ligament (Fig. 3-1). This ligament is in the shape of an isosceles triangle, the base of which extends between two iliopectineal eminerices and the vertex points to the front. This vertex is the point of attachment for the straight abdominal muscle ( $\mathrm{S}$ wieżyn $\mathrm{nsk}$, 1962). In adult European bisons the length of the branches of this ligament is, on the average, $165 \mathrm{~mm}$ and its thickness $4 \mathrm{~mm}$.

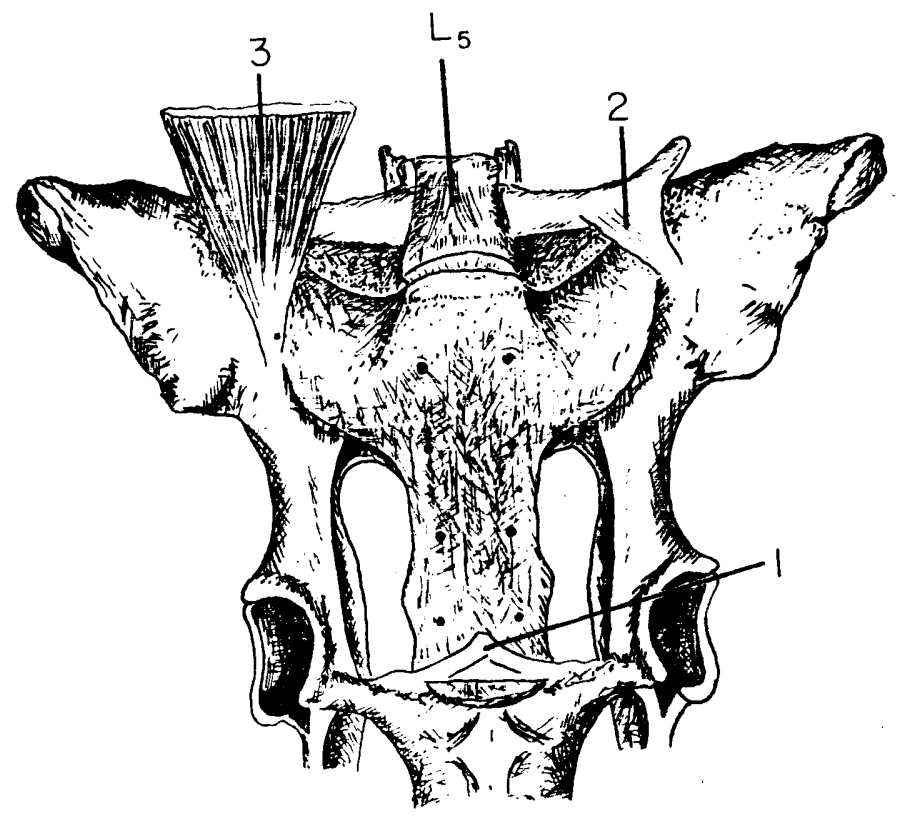

Fig. 3. Pelvic girdle, seen from the ventral side (14-years-old male).

1 - anterior pubic ligament, 2 - iliolumbar ligament, 3 - quadrate muscle of loins.

It should be mentioned, as a supplement to the study carried out by Empel \& R o s k o s z (1963), that the pelvic symphysis begins to ossify at the age of 8 years in males and a year earlier in females, the mere process of ossification taking 21 months in males and 18 months in females.

\subsection{Sacroiliac Joint}

In foetuses, just before birth, and in new-born bisons the auricular surfaces of the sacrum and ilium are united by a cartilaginous insertion, $4 \mathrm{~mm}$ thick. In cross-sections this insertion shows brown points arranged 
along the future articular cavity of the sacroiliac joint. In calves up to year of age these points are replaced by detached or combined spaces filled with the synovial fluid. Their number ranges from 15 to 25 . Such a multiple cavity of this joint occurs in 2-year-old European bisons. In specimens aged $2-9$ or 11 years there is a single articular cavity in the form of a fissure. In males from 9 or 11 to 14 years of age it becomes obliterated in favour of a fibrous joint and this, at the age above 14 years, changes into a synostosis, which in old males is so perfect that the boundary between the sacrum and ilium becomes effaced. In females the fibrous joint, appearing at the same time as it does in males, remains unossified throughout lifetime.

Table 2

Dimensions of obturator foramen (in $\mathrm{mm}$ ).

\begin{tabular}{|c|c|c|c|c|c|c|c|c|}
\hline \multirow{2}{*}{ Group } & \multirow{2}{*}{$\mathrm{n}$} & \multicolumn{3}{|c|}{ Length } & \multicolumn{3}{|c|}{ Width } & \multirow{2}{*}{$\begin{array}{c}\text { Length: width } \\
\text { ratio }\end{array}$} \\
\hline & & $\overline{\mathrm{x}}$ & s & $\mathrm{v}$ & $\overline{\mathbf{x}}$ & $\mathbf{s}$ & $\mathrm{v}$ & \\
\hline \multicolumn{9}{|c|}{ Males } \\
\hline 0 & 8 & 13.1 & 1.0 & 2.3 & 21.9 & 0.6 & 2.7 & $1: 0.51$ \\
\hline I & 5 & 54.4 & 6.2 & 11.4 & 32.2 & 4.8 & 14.8 & $1: 0.60$ \\
\hline II & 16 & 93.9 & 12.4 & 13.2 & 57.8 & 6.2 & 10.7 & $1: 0.62$ \\
\hline III & 17 & 108.0 & 5.7 & 5.3 & 68.6 & 3.7 & 5.4 & $1: 0.64$ \\
\hline IV & 15 & 109.9 & 6.1 & 5.6 & 70.0 & 3.7 & 5.3 & $1: 0.64$ \\
\hline $\mathrm{V}$ & 13 & 111.9 & 3.2 & 2.8 & 73.4 & 5.2 & 7.1 & $1: 0.64$ \\
\hline Growth & coeff. & 2.57 & & & 3.35 & & & \\
\hline \multicolumn{9}{|c|}{ Females } \\
\hline 0 & 4 & 36.0 & & & 17.0 & & & $1: 0.51$ \\
\hline I & 1 & - & & & - & & & - \\
\hline II & 9 & 86.8 & 9.3 & 10.7 & 53.6 & 4.7 & 8.8 & $1: 0.62$ \\
\hline III & 6 & 98.2 & 4.2 & 4.2 & 61.8 & 1.0 & 1.6 & $1: 0.68$ \\
\hline IV & 7 & 96.8 & 3.0 & 3.1 & 65.4 & 4.0 & 6.1 & $1: 0.68$ \\
\hline V & 18 & 98.4 & 2.0 & 2.0 & 65.7 & 2.4 & 3.6 & $1: 0.66$ \\
\hline Growth & coeff. & 2.73 & & & 3.81 & & & \\
\hline
\end{tabular}

The fibrous membrane of the capsule of the sacroiliac joint is a hard swollen lip surrounding the articular fissure. In young specimens it is richly impregnated with fibrocartilage. On the ventral side of the joint this membrane gives rise to the ventral sacroiliac ligament, from which silvery periosteous fibres run off. They extend medially and mingle with the fibrous ring of the intervertebral disc of the lumbosacral joint. Moreover, on the ventral side this joint capsule is strengthened by the insertion of the quadrate muscle of loins (Fig. 3-3).

The interosseous sacroiliac ligament of the European bison consists of a fairly large number of detached fibres stretched transversely in the gap between the wings of the sacrum and ilium.

The other ligaments in the sacroiliac joint of the European bison have been described by We g r z y n \& S e r watka (1961). 


\subsection{Obturator Membrane}

In European bisons this membrane is very thin, hardly $0.1-0.2 \mathrm{~mm}$ in thickness in adult specimens. It arises at the anterosuperior edge of the obturator foramen and extends posteromedially. Between this membrane and the free edges of the obturator foramen there is a crescent aperture, through which the internal obturator muscle comes out of the pelvic cavity. The obturator foramen is finally furnished with both obturator muscles. In the obturator membrane, close to the anterior edge of the foramen is the obturator canal, the lumen of which is equal to an index finger in diameter.

The obturator foramen is elliptic in shape. Its dimensions (Table 2) suggest that it attains its almost ultimate size in 4-year-old bisons. The growth coefficient is greater for the width than length, which indicates that the foramen becomes more and more rounded with age. Sexual dimorphism is revealed by the fact that the growth coefficients of this foramen are greater in females.

\subsection{Other Joints of the Pelvic Girdle}

The ventral surface of the ilium is united with the transverse process of the last lumbar vertebra by the iliolumbar ligament (Fig. 3-2). Its length averages $80 \mathrm{~mm}$ and the thickness $3.5 \mathrm{~mm}$ in adult specimens. An additional fibrous structure connecting the transverse process of the last lumbar vertebra to the hip tuberosity may appear in old European bisons.

\section{Hip Joint}

The external outline of the acetabulum of the European bison is intermediate between a circle and an isosceles triangle. The rim of the acetabulum is undulate in relation to its bottom and shows three eminences and three notches, an ilioischiatic, an iliopubic and an ischiopubic. This last is termed the acetabular notch proper. In absolute values the half of its width in the youngest specimens (Table 3 ). This width is, in addition, characterized by great individual variation.

On account of the ossification of the acetabular lip in this place, the iliopubic notch in the margin of the acetabulum may close to form an additional foramen for the passage of appropriate vessels.

The acetabular lip (Figs. 4, 5, 6-1), triangular in cross-section, is based on the edge of the acetabulum. Externally it passes into the periosteous fibres and on the side of the acetabular cavity unites with its articular cartilage. It is best developed in the ilioschiatic notch, where in the youngest specimens it reaches $7 \mathrm{~mm}$ in thickness and raises the edge of the acetabulum by $8 \mathrm{~mm}$. In adults it is respectively $12 \mathrm{~mm}$ 


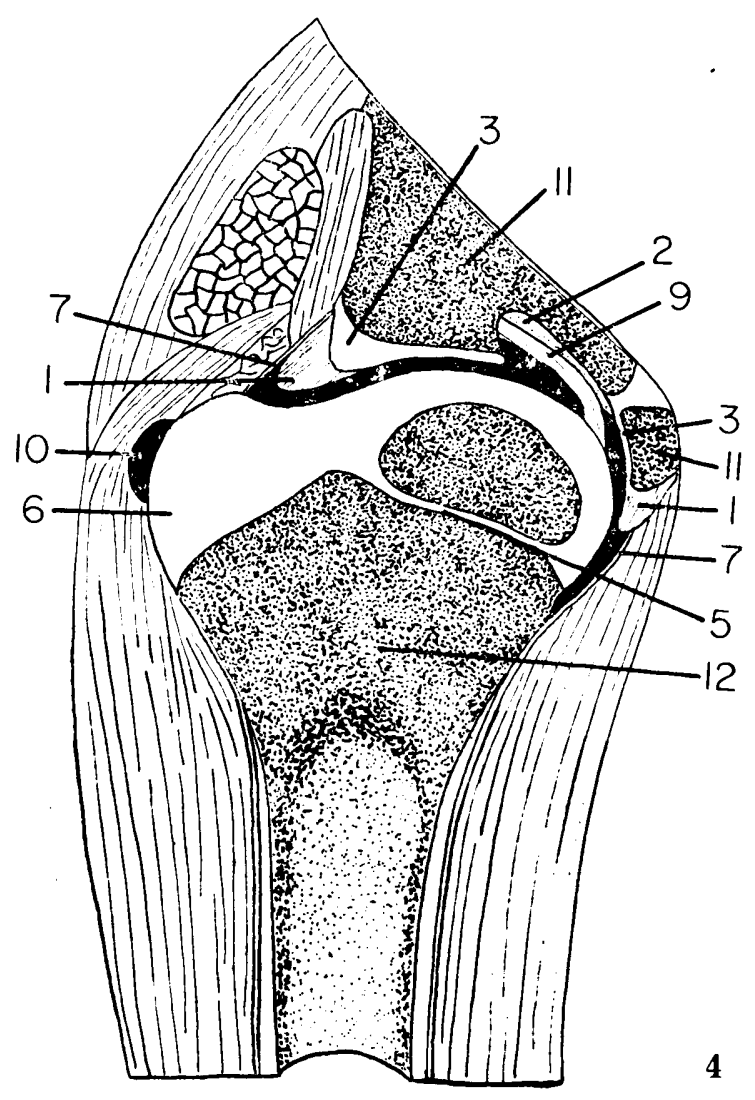

Fig. 4. Cross-section through the left hip joint, seen from behind (male foetus).

Fig. 5. Cross-section through the right hip joint, seen from behind (5-year-old male). Fig. 6. Anteromedial aspect of the hip joint (8-years-old female) (joint capsule filled with gelatin - black in colour in Figs. 4 and 5).

1 - acetabular lip, 2 - acetabular fossa, 3,4 - articular cartilage of acetabulum and femoral head, 5 - epiphyseal cartilage of femoral head, 6 - greater trochanter, 7 - articular capsule, 8 - ilioischiofemoral ligament, 9 - ligament of femoral head, 10 - trochanteric bursa of biceps muscle of thigh, 11 - pelvic bone, 12 femur. 


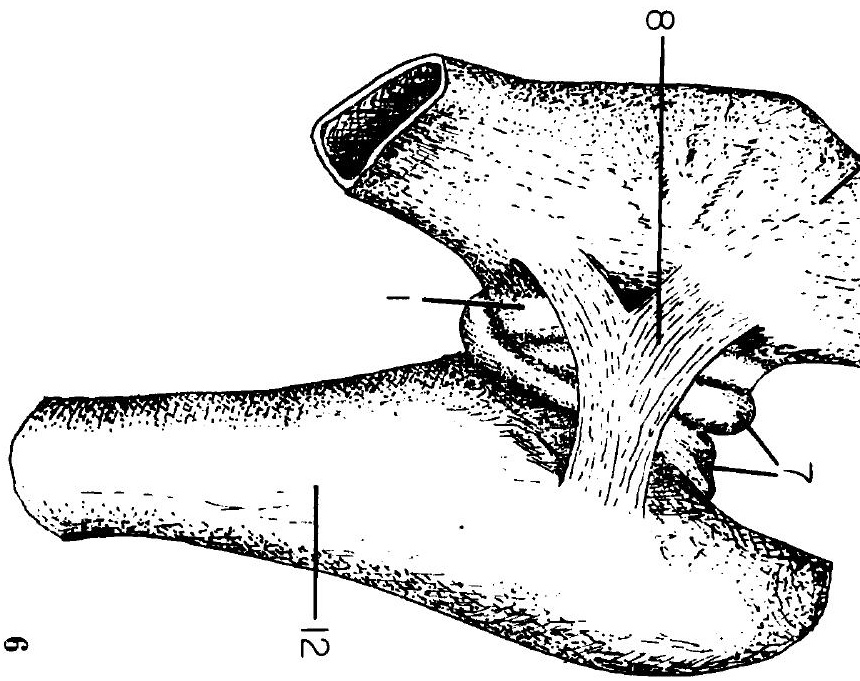




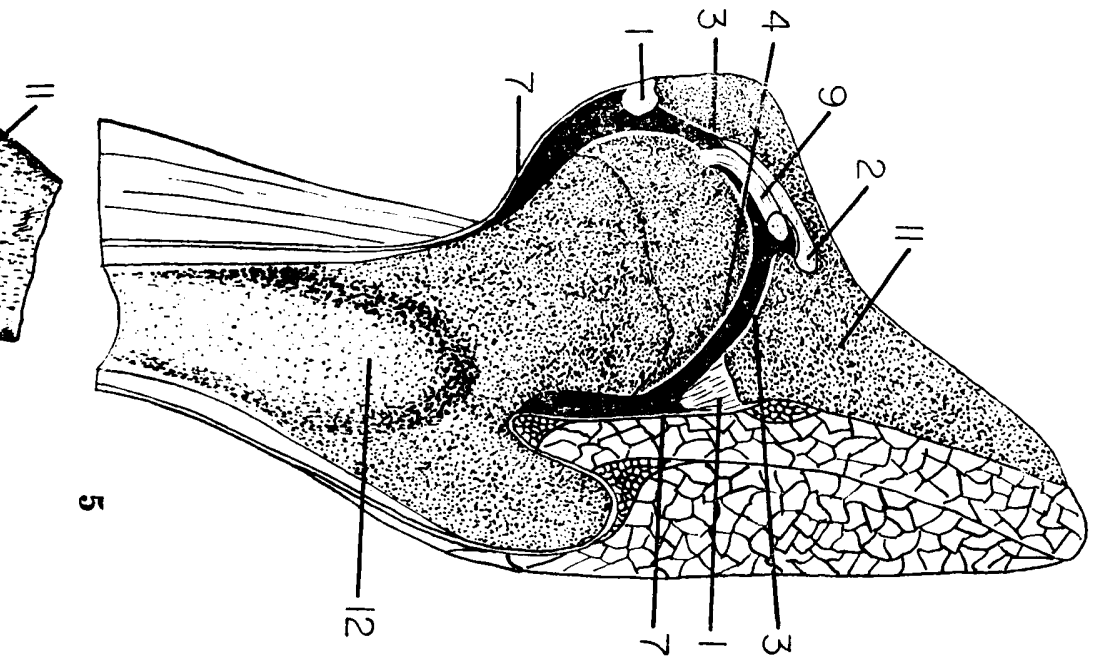


Table 3

Dimensions of pelvic acetabulum (in $\mathrm{mm}$ and $\mathrm{cu} . \mathrm{cm}$ ). G.C. - growth coefficient.

\begin{tabular}{|c|c|c|c|c|c|c|c|c|c|c|c|c|c|c|c|c|}
\hline \multirow{3}{*}{ Group } & \multirow{3}{*}{$\mathrm{n}$} & \multicolumn{6}{|c|}{ Dimension } & & \multirow{2}{*}{\multicolumn{3}{|c|}{ Capacity }} & \multirow{3}{*}{$\begin{array}{c}\text { Width } \\
\qquad \overrightarrow{\mathrm{x}}\end{array}$} & \multirow{2}{*}{\multicolumn{2}{|c|}{ of notch }} \\
\hline & & \multicolumn{3}{|c|}{ Vertical } & \multicolumn{3}{|c|}{ Horizontal } & & & & & & & & & \\
\hline & & $\overline{\mathrm{x}}$ & $\mathrm{S}$ & $\mathrm{V}$ & $\overline{\mathrm{x}}$ & $\mathbf{S}$ & $\mathrm{v}$ & $\overline{\mathrm{x}}$ & S & $\mathrm{v}$ & $\overline{\mathbf{x}}$ & $\mathrm{S}$ & $\mathbf{v}$ & & $\mathbf{S}$ & $\mathrm{v}$ \\
\hline \multicolumn{17}{|c|}{ Males } \\
\hline 0 & 8 & 36.1 & 2.0 & 5.5 & 38.4 & 3.0 & 7.8 & 20.3 & 5.0 & 24.6 & 12.2 & 1.2 & 9.8 & 10.3 & 1.0 & 9.7 \\
\hline 1 & 5 & 48.5 & 3.7 & 7.6 & 54.0 & 3.5 & 6.5 & 26.6 & 4.0 & 15.0 & 32.2 & 12.7 & 39.4 & 8.4 & 1.4 & 16.7 \\
\hline II & 16 & 62.7 & 1.7 & 2.7 & 67.0 & 2.2 & 3.3 & 42.3 & 1.7 & 4.0 & 72.4 & 8.1 & 11.2 & 7.5 & 2.9 & 38.7 \\
\hline III & 17 & 63.9 & 3.3 & 5.2 & 69.7 & 1.4 & 2.0 & 43.8 & 2.6 & 5.9 & 79.0 & 8.8 & 11.1 & 5.8 & 1.6 & 27.6 \\
\hline IV & 15 & 65.0 & 3.5 & 5.4 & 70.3 & 2.4 & 3.4 & 45.1 & 2.4 & 5.3 & 84.9 & 7.0 & 8.2 & 4.9 & 1.7 & 34.7 \\
\hline V & 13 & 64.9 & 1.4 & 2.2 & 71.6 & 3.5 & 4.9 & 45.2 & 4.9 & 10.8 & 88.6 & 6.3 & 7.1 & 4.9 & 1.3 & 26.5 \\
\hline G.C. & & 1.80 & & & 1.86 & & & 2.23 & & & 7.26 & & & 0.48 & & \\
\hline \multicolumn{17}{|c|}{ Females } \\
\hline 0 & 4 & 31.2 & & & 34.7 & & & 17.6 & & & 9.5 & & & 10.5 & & \\
\hline I & 1 & 47.0 & & & 48.0 & & & 26.4 & & & 31.0 & & & 6.0 & & \\
\hline II & 9 & 55.3 & 2.4 & 4.3 & 58.6 & 2.8 & 4.8 & 34.7 & 2.2 & 6.3 & 51.5 & 8.1 & 15.7 & 7.1 & 2.1 & 29.6 \\
\hline III & 6 & 58.0 & 3.3 & 5.7 & 62.5 & 2.4 & 3.8 & 37.4 & -2.1 & 5.6 & 58.3 & 4.7 & 8.1 & 5.6 & 2.3 & 41.1 \\
\hline IV & 7 & 58.0 & 1.4 & 2.4 & 63.4 & 2.0 & 3.2 & 38.8 & 1.7 & 4.4 & 61.5 & 3.2 & 5.2 & 6.1 & 2.0 & 32.8 \\
\hline V & 18 & 58.4 & 3.0 & 5.1 & 63.5 & 1.7 & 2.7 & 39.7 & 3.7 & 9.3 & 66.2 & 6.1 & 9.2 & 5.1 & 1.4 & 27.4 \\
\hline G.C. & & 1.88 & & & 1.83 & & & 2.26 & & & 6.97 & & & 0.48 & & \\
\hline
\end{tabular}


thick and $15 \mathrm{~mm}$ wide. At the height of the acetabular notch the lip passes into the transverse acetabular ligament (see further).

The outline of the lunate articular surface of the acetabulum is 8-shaped in the youngest European bisons and consistent with its name in adults. Its pars major is divided from the pars minor by a rough surface having the structure of synovial fossae.

The acetabular fossa (Figs. 4, 5-2) is approximately twice as large in area in the youngest European bisons as it is in adults. In foetuses and newborns the meeting point of the three bones of the pelvic girdle is visible at the centre of the fossa as a small triangular field built merely of a thin membrane of connective tissue. Three lines of synchondroses radiate from the central point of the acetabular fossa and divide the circumference into three equal parts.

The capacity of the osseous acetabular socket (Table 3), i.e. the socket without its lip, attains its almost final value in the four-year-old bison. The growth coefficient of the depth of this socket (Table 3) exceeds this coefficient for its vertical and horizontal dimensions, which indicates that in foetuses and newborns the sockets are relatively shallower than they are in adults. The proportions of the three basic linear dimensions show that one-year-old European bisons already have their sockets ultimately shaped.

The sockets with the lip preserved are deeper than those without the lip by $5.5 \mathrm{~mm}$ in foetuses and newborns and by $8 \mathrm{~mm}$ in adults.

In foetuses and newborns the articular cartilage of the acetabulum (Figs. 4, 5-3) is $1.8 \mathrm{~mm}$ thick in the pars minor of the acetabular surface and up to $2.4 \mathrm{~mm}$ in the pars major. In adults the thickness of this cartilage is the same in both parts, about $0.9 \mathrm{~mm}$. In the youngest specimens the articular cartilage passes into the synchondroses of the three bones of the pelvic girdle meeting in the socket.

Geometrically, the head of the femur of European bisons is a combination of a cone and a hemisphere. Mounted on the neck of the femur, it forms with the shaft an angle of $130^{\circ}$, which opens ventromedially. The growth coefficients for the vertical and horizontal dimensions of the head (Table 4) exceed these coefficients for the respective dimensions of the acetabulum (Table 3). Thus, it may be inferred indirectly that in postnatal life the volume of the femoral head of the European bison increases more than does the capacity of the acetabulum.

The articular cartilage of the femoral head (Figs. 4, 5-4) blends peripherally with the epiphyseal cartilage (Fig. 4-5) in foetuses and newborns. In the same specimens the articular cartilage covers also the surface of the neck, merging into the cartilaginous structure of the greater trochanter on the outside (Fig. 4-6). In adults this cartilage 
covers only the articular surface of the head except for its fovea. The thickness of this cartilage in the youngest specimens is $4 \mathrm{~mm}$ close to the depression of the head and $5-6 \mathrm{~mm}$ in the periphery. In adults it is more or less uniform, $1.0-1.5 \mathrm{~mm}$.

In foetuses and newborns the capsule of the hip joint (Figs. 4, 5, 6-7) is attached by mean of its fibrous membrane to the femur just below the line of epiphyseal cartilage and extends as far as the greater trochanter on the dorsal side. Its other attachment occurs on the acetabular lip. In adult European bisons the attachment of the joint capsule to the femur is shifted in comparison with its place in the youngest specimens beyond the line of the former epiphyseal cartilage on the dorsal side

Table 4

Dimensions of femoral head (in $\mathrm{mm}$ ).

\begin{tabular}{|c|c|c|c|c|c|c|c|}
\hline \multirow{2}{*}{ Group } & \multirow{2}{*}{$\mathrm{n}$} & \multicolumn{3}{|c|}{ Vertical dimension } & \multicolumn{3}{|c|}{ Horizontal dimension } \\
\hline & & $\overline{\mathrm{x}}$ & $\mathrm{s}$ & $\mathrm{v}$ & $\overline{\mathrm{x}}$ & $\mathrm{s}$ & $\mathrm{v}$ \\
\hline \multicolumn{8}{|c|}{ Males } \\
\hline 0 & 8 & 27.4 & 1.3 & 4.7 & 28.3 & 3.1 & 11.0 \\
\hline I & 5 & 38.7 & 4.5 & 11.6 & 42.4 & 3.0 & 7.1 \\
\hline$\hat{\text { II }}$ & 16 & 52.2 & 1.7 & 3.2 & 56.8 & 1.5 & 4.4 \\
\hline III & 17 & 55.8 & 1.5 & 2.7 & 58.8 & 2.6 & 2.6 \\
\hline IV & 15 & 58.3 & 1.0 & 1.7 & 60.3 & 3.3 & 5.5 \\
\hline $\mathrm{V}$ & 13 & 58.8 & 1.4 & 2.4 & 60.9 & 1.9 & 3.1 \\
\hline Growth & coeff. & 2.14 & & & 2.15 & & \\
\hline \multicolumn{8}{|c|}{ Females } \\
\hline 0 & 4 & 23.7 & & & 24.5 & & \\
\hline I & 1 & 37.5 & & & 43.3 & & \\
\hline II & 9 & 47.0 & 1.8 & 3.8 & 50.0 & 6.7 & 13.4 \\
\hline III & 6 & 50.4 & 1.4 & 2.1 & 53.6 & 2.0 & 3.7 \\
\hline IV & 7 & 51.9 & 2.0 & 3.8 & 548 & 2.0 & 3.6 \\
\hline V & 18 & 52.1 & 1.4 & 2.7 & 55.3 & 2.0 & 3.6 \\
\hline Growth & coeff. & 2.20 & & & 2.26 & & \\
\hline
\end{tabular}

and extends to the place where the neck passes into the shaft of the bone on the ventral side. Thus, in both cases in adult specimens the fibrous membrane of the capsule of this joint is attached to the femoral head at a distance of about $2 \mathrm{~cm}$ from the edge of the articular surface to the outside. As in the youngest specimens, its other attachment is on the acetabulum.

Two parts of the synovial membrane can be distinguished in the hip joint of the European bison. One of them participates in the formation of the joint capsule, the other is connected with the ligament of the femoral head (see further).

In foetuses and newborns the synovial membrane, which goes to the making of the joint capsule accompanies the fibrous membrane 
from one attachment to the other. In adults a similar situation is observed as regards the attachments of both membranes to the acetabulum, whereas on the femur the synovial membrane is attached to the edges of the articular cartilage, from where it goes on to the circumference, to the attachments of the fibrous membrane, thus covering the neck stripped of articular cartilage. It has however been found that the synovial membrane covering the femoral neck in middle-aged European bisons disappears in old specimens.

The capsule of the hip joint is moderately tense. It is thickest on the dorsal side. On the posterior side of the joint it forms a recess the size of a cherry, which is pressed into the trochanteric fossa as the synovial bursa of the obturator muscles.

The capacity of the cavity of the hip joint is $11-17 \mathrm{ml}$ in age group $0,20-29 \mathrm{ml}$ in group I, 27-40 $\mathrm{ml}$ in group II and on the average $36-50 \mathrm{ml}$ in adults. The lower limits refer to females, the upper ones to males. The amount of the synovial fluid that I managed to obtain from the cavity of this joint was $6-8 \mathrm{ml}$ in adults.

\section{Ligaments of the Hip Joint}

The ilioischiofemoral ligament (Fig. 6-8) begins antero-inferiorly at the base of the greater trochanter and ends, split into two portions, in the region of the ischiatic spine. Its undivided part is $20 \mathrm{~mm}$ wide and $2.5 \mathrm{~mm}$ thick in foetuses and newborns and, respectively, 45 and $5 \mathrm{~mm}$ in adults.

The transverse acetabular ligament connects the margins of the acetabular notch and at the same time bounds the acetabular foramen, through which run the extra-acetabular portion of the ligament of the femoral head and ramifications of the synovial membrane with small vessels. The length of this ligament corresponds to the width of the acetabular notch (Table 3). Its width is $8.2 \mathrm{~mm}$ and the thickness $3.0 \mathrm{~mm}$ in the youngest European bisons and, respectively, 17.6 and $7.3 \mathrm{~mm}$ in adults. The medial edge of the transverse acetabular ligament gives attachment to a part of the ligament of the femoral head.

The ligaments of the femoral head (Figs. 4, 5-9) arises in the fovea of the femoral head and runs towards the acetabular notch. Here, it divides into a part that ends in the periosteum of this notch and a part that mingles with the transverse acetabular ligament. A band branches off the latter part and passes out of the acetabular cavity through the acetabular foramen to terminate in a special groove of the ischium. This band is an extra-acetabular portion of the ligament of the ligament of the femoral head.

Starting from its attachment to the femur the ligament discussed is 
accompanied by a fold of the synovial membrane, which enwraps it. In the region of the acetabular fossa the fold widens calix-like and is attached to the edges of this fossa without coming into contact with its bottom. A part of the synovia membrane enters the acetabular foramen to accompany the extra-acetabular portion of the ligament under discussion.

The length of the ligament of the femoral head is $25 \mathrm{~mm}$ in foetuses and newborns of both sexes, $35 \mathrm{~mm}$ in adult males and $31 \mathrm{~mm}$ in adult females. The ratio of the length of this ligament to the horizontal dimension of the acetabulum is as $0.65: 1$ in the group of the youngest males and on the average as $0.50: 1$ for adult males. In females this ratio is as $0.72: 1$ in the youngest group and as $0.49: 1$ for adults. If in turn the length of this ligament is compared with the horizontal dimension of the femoral head, the ratio is, respectively, as $0.88: 1$ and $0.59: 1$ for the youngest and adult males and as 1.0:1 and 0.57:1 for the youngest and adult females. These comparisons show that the ligament of the femoral head is relatively longer and, what is more, considerably longer in the first days of life of European bisons than it is in adult specimens.

As regards the thickness and width of the ligament concerned, individual variation is very great. In group 0 of males the width averages $4.7 \mathrm{~mm}$, ranging from 3.6 to $6.0 \mathrm{~mm}$, whereas in adult males the mean is $13.5 \mathrm{~mm}$ and the range $8.4-19.0 \mathrm{~mm}$. These data in females are $\bar{x}=$ $6.7 \mathrm{~mm}(3.5-8.8 \mathrm{~mm})$ for the youngest specimens and $\bar{x}=11.5 \mathrm{~mm}$ $(5.0-17.0 \mathrm{~mm})$ for adults. Somewhat smaller individual variation is observed in the thickness of this ligament. The mean thickness is $3.0 \mathrm{~mm}$ $(2.0-3.5 \mathrm{~mm})$ for groups 0 of both sexes and, respectively, $5.5 \mathrm{~mm}$ $(3.0-8.0 \mathrm{~mm})$ and $7.5 \mathrm{~mm}(5.0-10.0 \mathrm{~mm})$ for adult males and females.

\section{Stifle Joint}

\subsection{Femorotibial Joint}

The condyles of the femur and the long axis of this bone form an angle of $110^{\circ}$, open to the rear. The length, or the chord, and the width of one condyle approximate the corresponding dimensions of the other (Table 5). The length:width ratio of the condyles changes with age in favour of the first dimension (Table 5). The angle of the curvature of the medial condyle is somewhat greater than that of the lateral condyle (Table 5) or, in other words, the medial condyle is more convex than the lateral. The length of the curvature radius of the lateral condyle (Table 5) is mostly somewhat greater than that of the medial. The lateral condyle lies in a sagittal plane, whereas the medial one deflects medially 
from this plane at an angle of $20^{\circ}$. The medial condyle is, in addition, pushed farther to the back and, as a result, the rotation axis in the femorotibial joint runs obliquely to the sagittal plane, with which it forms an angle of $77^{\circ}$.

\section{Table 6}

Dimensions of distal end of femur (in $\mathrm{mm}$ ).

A - width ratio of distal end of femur to intercondylar fossa.

\begin{tabular}{|c|c|c|c|c|c|c|c|c|c|c|c|}
\hline \multirow[t]{2}{*}{ Group } & \multirow[t]{2}{*}{$\mathbf{n}$} & \multicolumn{2}{|c|}{ Lenght } & \multicolumn{4}{|c|}{ Width } & \multicolumn{3}{|c|}{$\begin{array}{l}\text { Width of intercon- } \\
\text { dylar fossa }\end{array}$} & \multirow[t]{2}{*}{$\mathbf{A}$} \\
\hline & & $\overline{\mathbf{x}}$ & s & $\mathrm{v}$ & & $\mathrm{s}$ & $\mathrm{v}$ & $\overline{\mathrm{x}}$ & $\mathbf{s}$ & $\mathrm{v}$ & \\
\hline \multicolumn{12}{|c|}{ European bison, males } \\
\hline 0 & 8 & 77.3 & 7.2 & 9.3 & 67.3 & 3.2 & 4.8 & 20.8 & 2.4 & 11.5 & $1: 0.31$ \\
\hline I & 5 & 102.5 & 2.8 & 2.7 & 85.0 & 5.6 & 6.6 & 19.5 & 1.4 & 7.2 & $1: 0.23$ \\
\hline II & 16 & 134.7 & 8.2 & 6.1 & 105.2 & 5.6 & 5.3 & 18.1 & 0.6 & 3.3 & $1: 0.17$ \\
\hline III & 17 & 144.2 & 8.1 & 5.6 & 114.9 & 4.0 & 3.5 & 17.6 & 1.0 & 5.7 & $1: 0.15$ \\
\hline IV & 15 & 144.6 & 5.7 & 3.9 & 117.3 & 3.9 & 3.3 & 17.1 & 2.0 & 11.7 & $1: 0.14$ \\
\hline $\begin{array}{l}\mathrm{V} \\
\text { G. C. }\end{array}$ & 13 & $\begin{array}{r}144.3 \\
1.78\end{array}$ & 6.1 & 4.2 & $\begin{array}{r}120.8 \\
1.79\end{array}$ & 7.2 & 6.0 & $\begin{array}{l}17.1 \\
0.82\end{array}$ & 1.0 & 5.8 & $1: 0.14$ \\
\hline \multicolumn{12}{|c|}{ European bison, females } \\
\hline 0 & 4 & 79.5 & & & 64.0 & & & 18.7 & & & $1: 0.29$ \\
\hline I & 1 & 103.0 & & & 82.0 & & & 20.0 & & & $1: 0.24$ \\
\hline II & 9 & 117.8 & 9.0 & 7.6 & 94.4 & 6.2 & 6.6 & 18.2 & 1.1 & 6.0 & $1: 0.19$ \\
\hline III & 6 & 128.0 & 4.0 & 3.1 & 103.6 & 3.0 & 2.9 & 17.4 & 1.6 & 9.2 & $1: 0.17$ \\
\hline IV & 7 & 131.0 & 2.6 & 2.0 & 104.5 & 7.4 & 7.1 & 17.8 & 1.4 & 7.9 & $1: 0.17$ \\
\hline $\begin{array}{l}\text { V. } \\
\text { G. C. }\end{array}$ & 18 & $\begin{array}{r}136.2 \\
1.72\end{array}$ & 6.7 & 4.9 & $\begin{array}{r}109.0 \\
1.70\end{array}$ & 3.6 & 3.3 & $\begin{array}{l}17.5 \\
0.94\end{array}$ & 1.8 & 10.3 & $1: 0.16$ \\
\hline \multicolumn{12}{|c|}{ Bison bison L., females } \\
\hline & 4 & 126.9 & & & 93.6 & & & 14.2 & & & $1: 0.15$ \\
\hline \multicolumn{12}{|c|}{ Bison bonasus - Bison bison hybrid, male } \\
\hline & 1 & 147.0 & & & 126.0 & & & 13.8 & & & $1: 0.11$ \\
\hline \multicolumn{12}{|c|}{ Domestic cattle, males } \\
\hline & 2 & 159.0 & & & 131.8 & & & 15.4 & . & & $1: 0.12$ \\
\hline \multicolumn{12}{|c|}{ Domestic cattle, females } \\
\hline & 10 & 135.4 & 10.2 & 7.5 & 100.8 & 1.4 & 1.4 & 15.2 & 2.0 & 7.9 & $1: 0.15$ \\
\hline \multicolumn{12}{|c|}{ Watussi cattle, male } \\
\hline & 1 & 140.5 & & & 124.5 & & & 11.1 & & & $1: 0.09$ \\
\hline \multicolumn{12}{|c|}{ Watussi cattle, female } \\
\hline & 1 & 131.0 & & & 106.5 & & & 11.2 & & & $1: 0.11$ \\
\hline \multicolumn{12}{|c|}{ Bubalus bubalus L., male } \\
\hline & 1 & 135.5 & & & 113.0 & & & 17.2 & & & $1: 0.15$ \\
\hline \multicolumn{12}{|c|}{ Zebu, female } \\
\hline & 1 & 119.0 & & & 94.5 & & & 13.6 & & & $1: 0.14$ \\
\hline \multicolumn{12}{|c|}{ Yak, female } \\
\hline & 1 & 91.5 & & & 81.0 & & & 6.5 & & & $1: 0.8$ \\
\hline
\end{tabular}


The intercondylar fossa becomes narrower with age (Table 6). Consequently, the width ratio of the distal end of the femur to this fossa changes during postnatal life (Table 6). As the length of the distal end of the femur hardly differs from the width in growth coefficient (Table 6), its comparison with the width of the intercondylar fossa gives a similar ratio.

The articular cartilage of the femoral condyles (Fig. 8-1) changes its colour in course of life. In foetuses and newborns it is pale blue, in animals above one year of age cream, and in the oldest ones almost white with patches in brick-red colour. In some males, more than 15

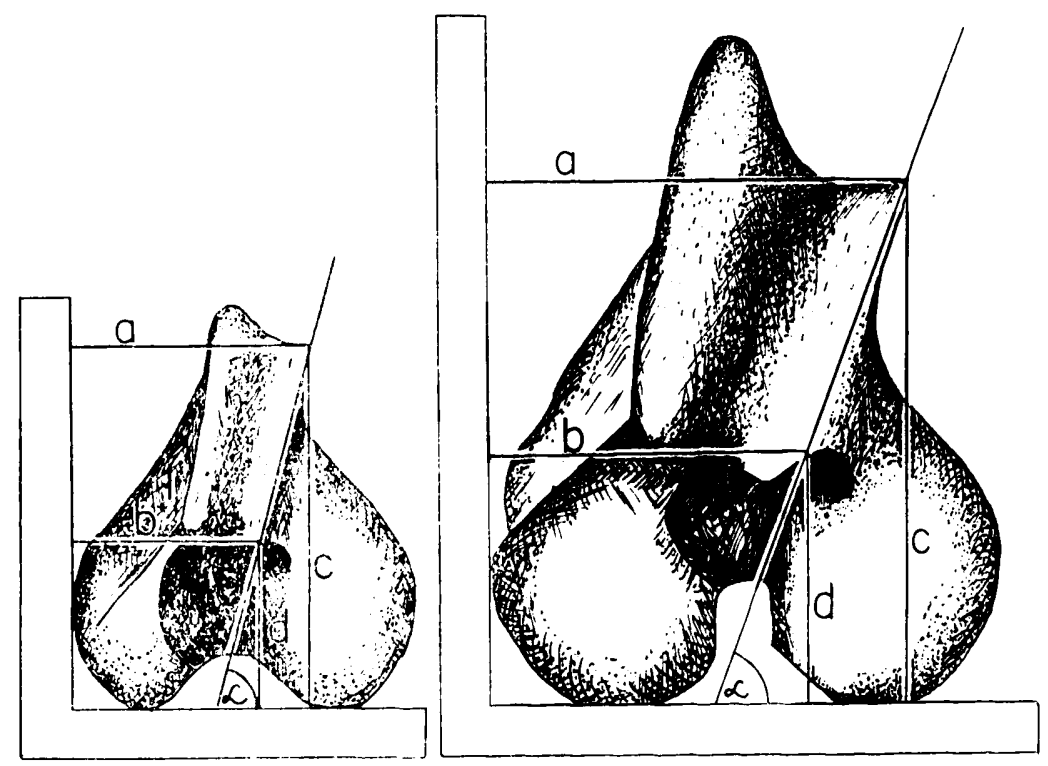

Fig. 7. The angle of inclination $(\alpha)$ of the femoral trochlea in the foetus (left) and the adult European bison (right).

a, b, c - auxiliary lines used to calculate the angle $\alpha$.

years old, and in females 2-3 years older, degenerative changes appear in this cartilage, affecting circular areas, $1-2 \mathrm{~cm}$ in diameter, adjacent to the intercondylar fossa. In males the thickness of the articular cartilage on the lateral condyle is $5.7 \mathrm{~mm}$ in group $0,3.0 \mathrm{~mm}$ in group I and $1.3 \mathrm{~mm}$, with small deviations, in the other groups, and in females it is, respectively, 4.4, 1.4 and $1.3 \mathrm{~mm}$. On the medial condyle the thickness of this cartilage is $6.3 \mathrm{~mm}$ in group $0,2.7 \mathrm{~mm}$ in group I and $1.3 \mathrm{~mm}$ in the remaining groups in males and, respectively, $3.9,1.2$ and $1.3 \mathrm{~mm}$ in females.

The articular surfaces of the tibial condyles resemble saddles in shape. Their articular cartilage (Figs. 8, 9, 10-2) is characterized by physical 
features similar to those of the cartilage described above, not excluding pathological changes, which on both condyles occur in the vicinity of the appropriate intercondylar tubercles. The thickness of this cartilage on both condyles is $2.6 \mathrm{~mm}$ in the youngest males and $1.7-1.8 \mathrm{~mm}$ in the remaining ones, whereas in females it is, respectively, 2.2 and $1.3-1.4$ $\mathrm{mm}$. In foetuses and newborns the articular cartilage of the condyles of the tibia passes into its epiphyseal cartilage (Fig. 10-3).

\section{Menisci}

The menisci of European bisons, the lateral (Figs. 8, 11, 12, 13, 15, 16-4) and the medial (Figs. 11, 12, 14, 15, 16-5), resemble the conchae of human ear in outline. In most cases the lateral meniscus is slightly longer and broader than the medial one (Table 7). Both these fibrocartilages are thinnest in the middle of their length, the lateral meniscus being thickest at the back and the medial one in the front. In the course of postnatal life the relative thickness at the back of the lateral meniscus increases considerably, becoming smaller in the middle portion. The shape of the medial meniscus hardly changes during life. The thickness given in Table 7 is a mean value from its three measurements analysed. Sexual dimorphism is manifested by the fact that in males the growth coefficient of the thickness is greater for the medial meniscus in contradistinction to the situation in females. In both sexes this thickness is much greater in the lateral meniscus. As regards volume, the lateral meniscus exceeds the medial, but not strikingly (Table 7). In analysing the increments in this parameter, one can see that the menisci of males attain their final size earlier than those of females. In the oldest specimens the menisci sometimes undergo deformation. Their peripheral margins lose their characteristic semicircular line and the fibrous processes their morphological distinctness, the axial margins look like unhemmed fabric and the notches become lengthened and deepened. The menisci are cream in colour, with brick-red stripes.

\section{Mieniscal Ligaments}

The anterior tibial ligament of the lateral meniscus (Fig. 11-7) arises from the anterior end of the meniscus and ends between the layers of the anterior cruciate ligament in the medial intercondylar area.

The anterior tibial ligament of the medial meniscus (Fig. 11-8) is the extension of the anterior end of the meniscus. It ends in front of the attachment of the previous ligament in the lateral intercondylar area.

The anterior ligaments of the menisci form an obtuse angle, pointing to the front. This angle is $180^{\circ}$ in the phase of extension and $130^{\circ}$ in the phase of flexion. 

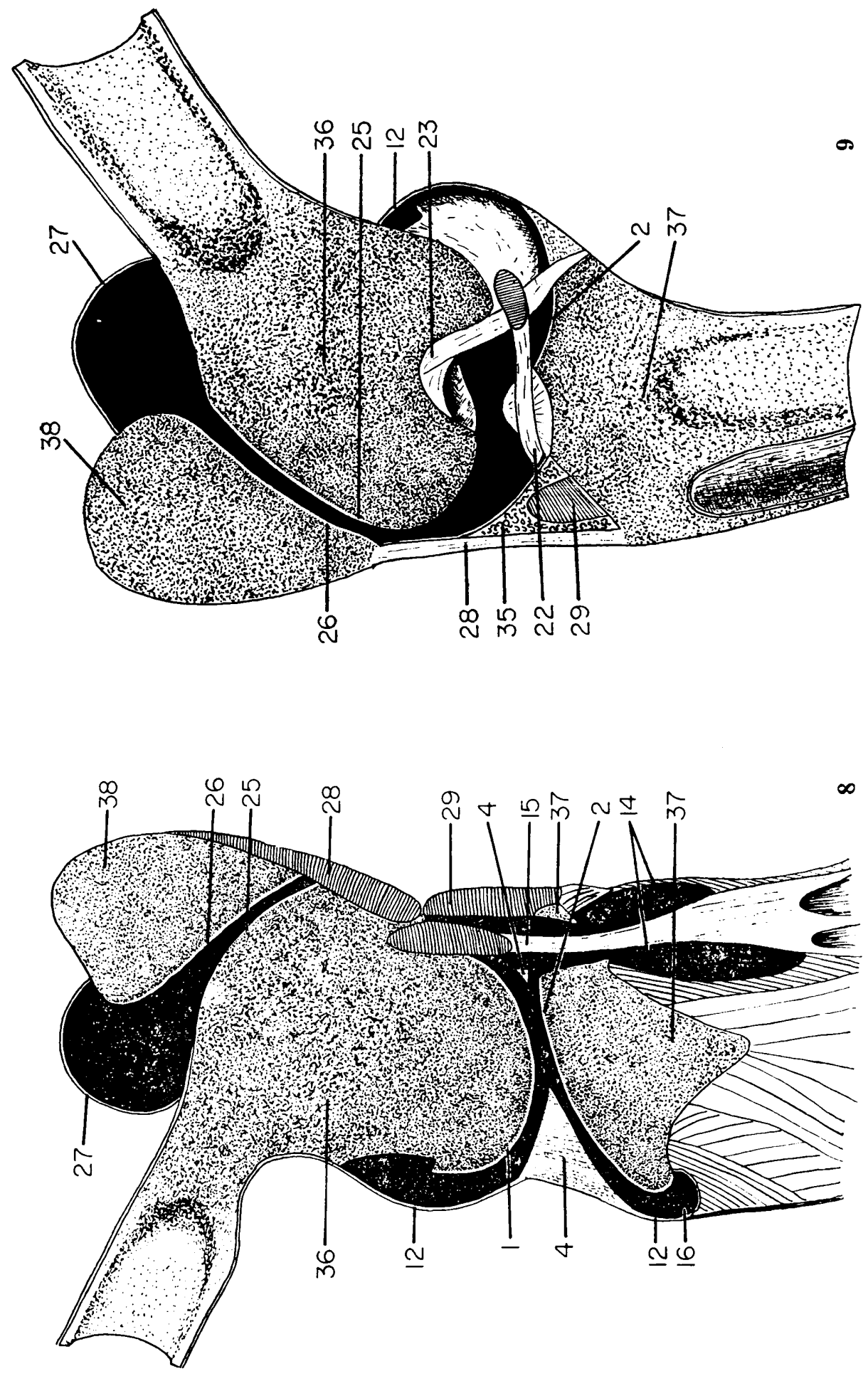

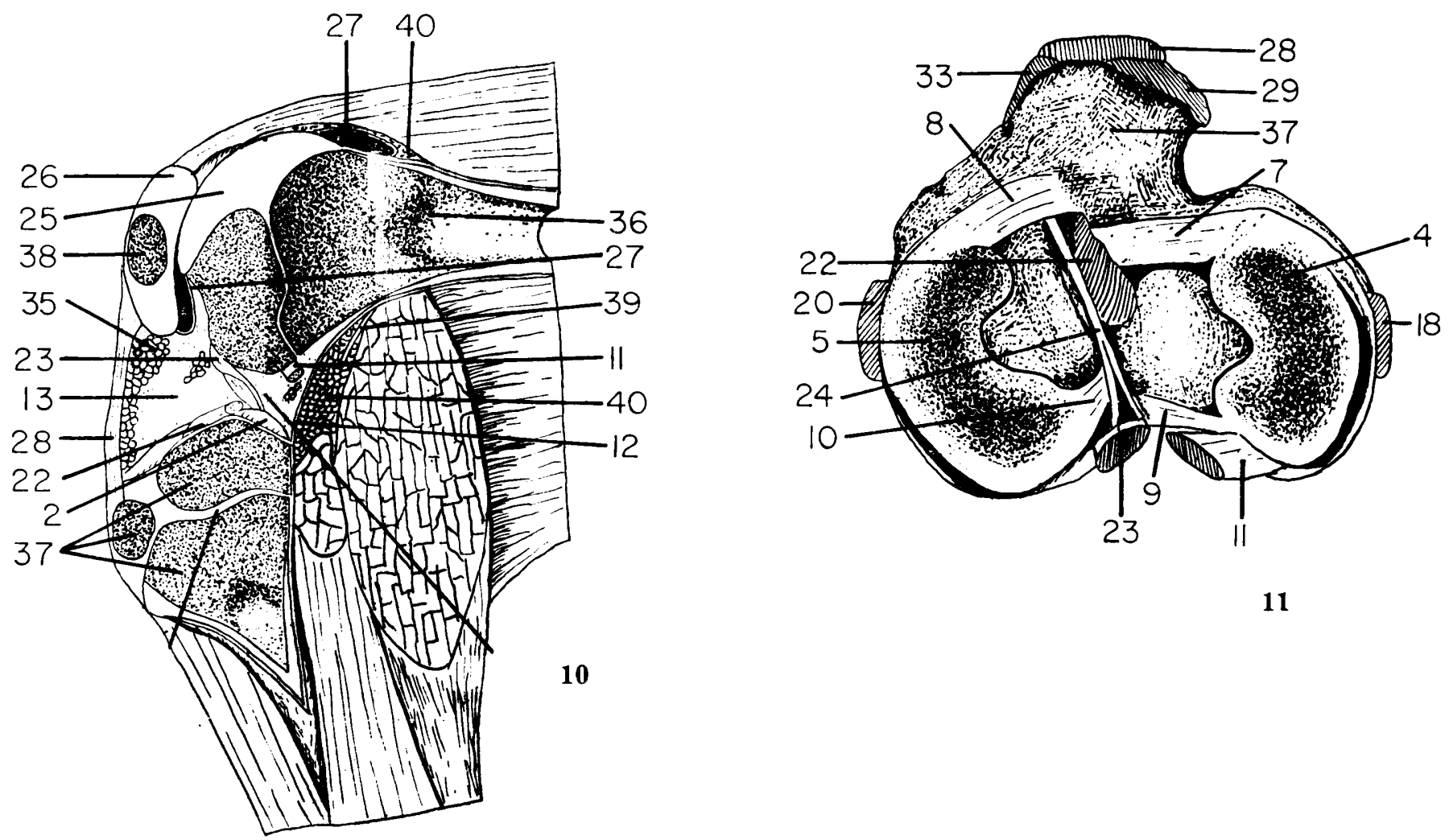

Fig. 8. Sagittal section of right stifle joint through lateral femoral condyle. Medial view (8-year-old male).

Fig. 9. Sagittal section through the middle of the left stifle joint. Lateral view (8-year-old male).

Fig. 10. Same as Fig. 9 (male foetus).

Fig. 11. Menisci of the right femorotibial joint, seen from above (9-year-old female). Explanations to figures $8-16$ see page 60 . 

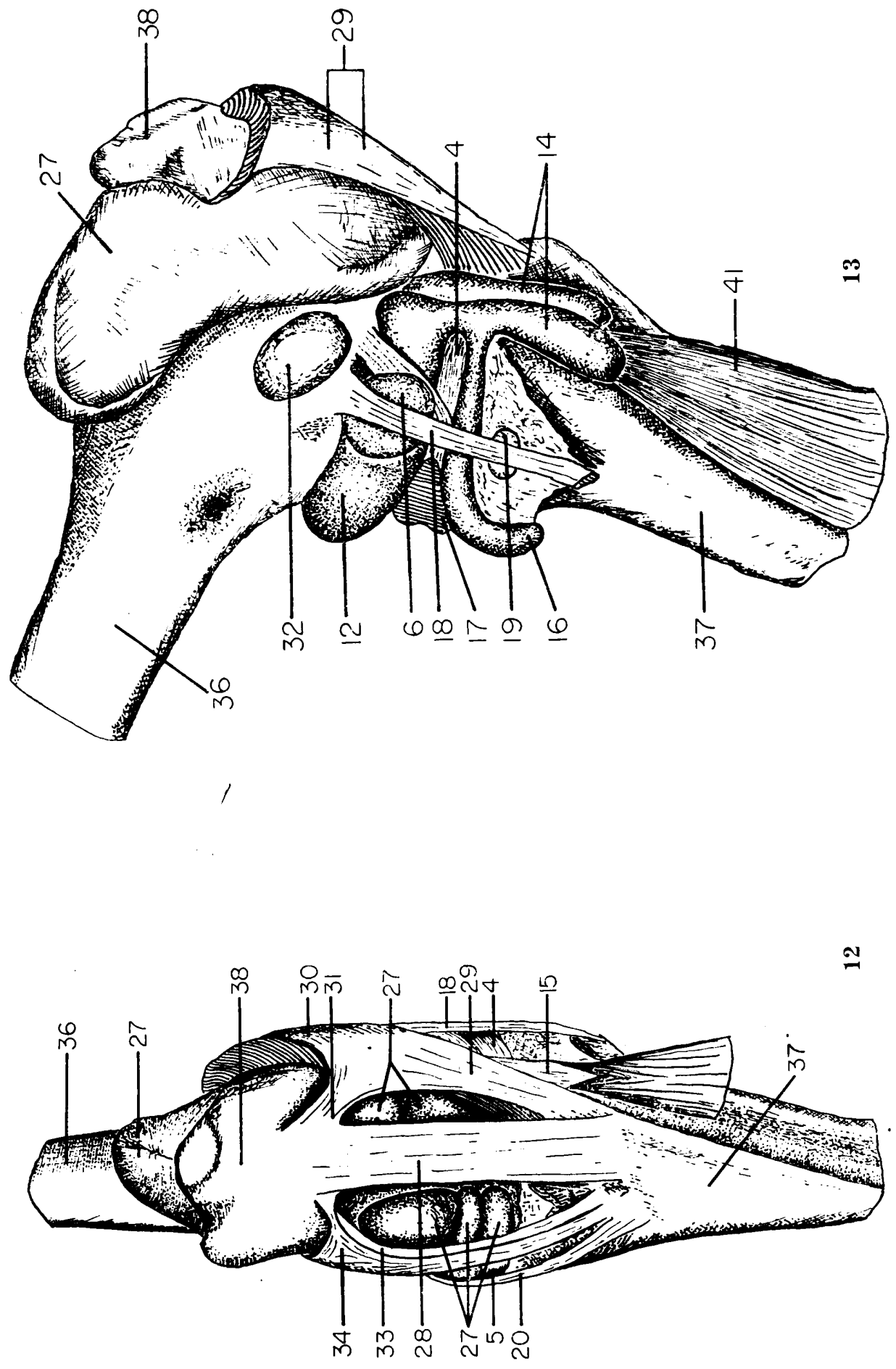


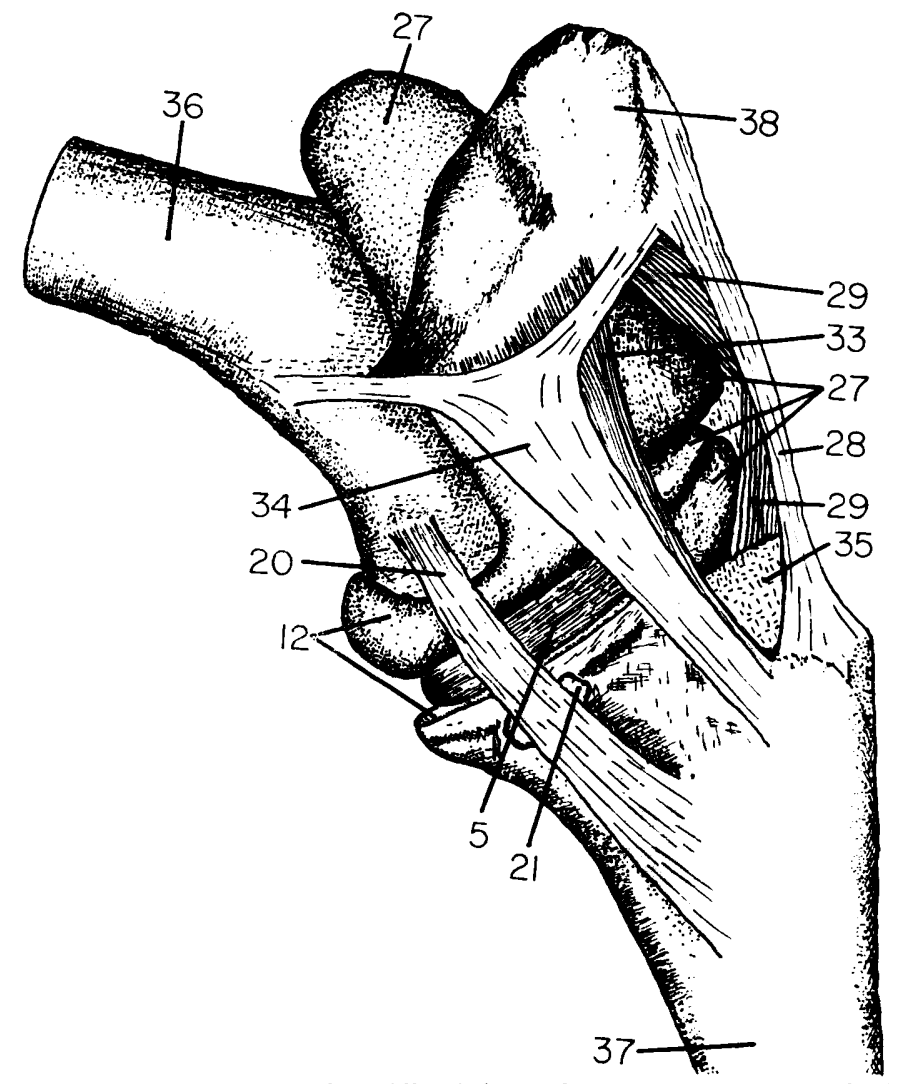

14

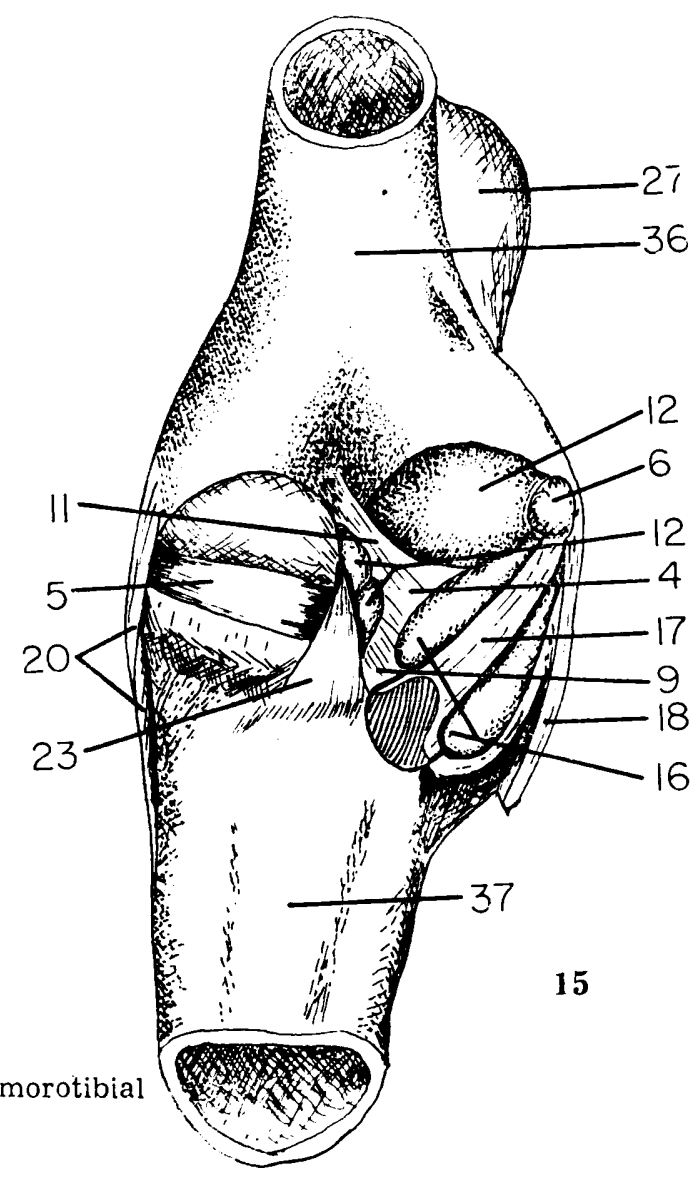

Fig. 13. Right stifle joint. Lateral view (8-year-old male).
Fig. 14. Left stifle joint. Medial view (10-year-old male).

Fig. 15. Right stifle joint after the removal of the medial sac of the femorotibial joint. Posterior view (8-year-old male). 


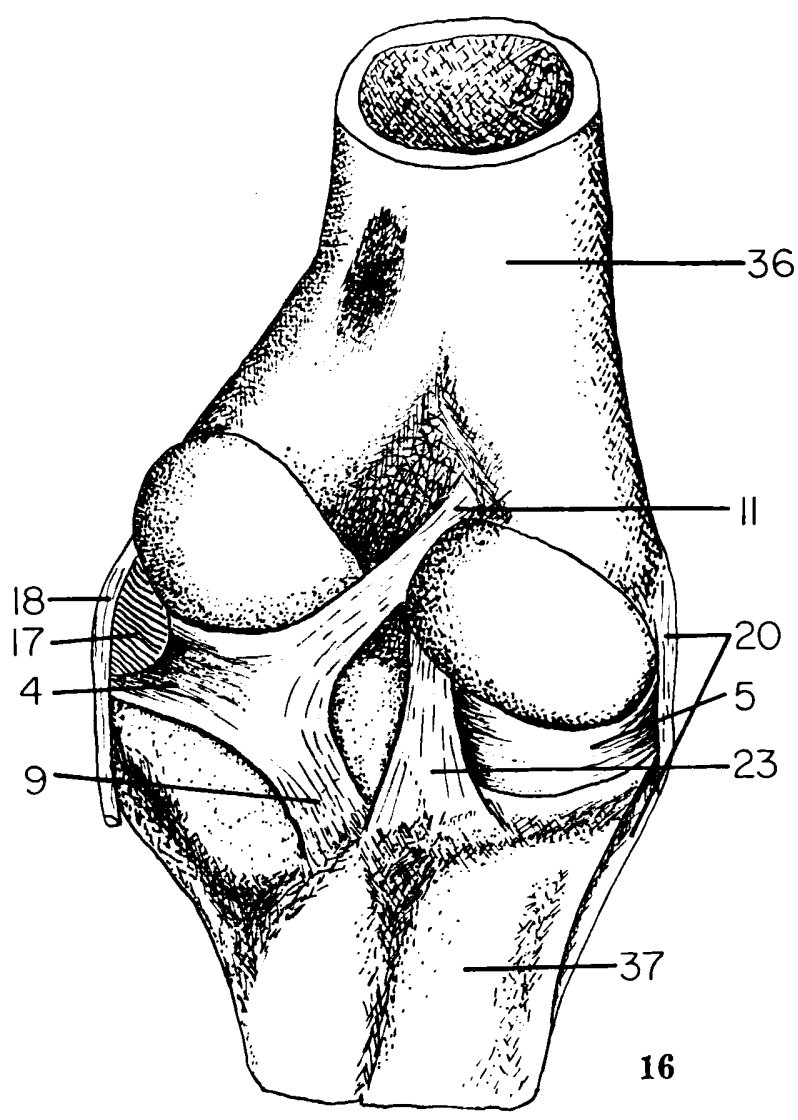

Fig. 16. Left stifle joint after the removal of the joint capsule. Posterior view (10-year-old male).

(In Figs. 8, 9, 10, 12, 13, 14 and 15 the joint capsules are filled with gelatin; in Figs. 8 and 9 - black in colour).

1, 2 - articular cartilage of femoral and tibial condyles. 3 - epiphyseal cartilage of tibia, 4, 5 -- lateral and medial menisci, 6 - proximal bursa of lateral collateral ligament, 7, 8 - anterior tibial ligaments of lateral and medial menisci, 9, $10-$ posterior tibial ligaments of lateral and medial menisci, 11 - femoral ligament of lateral meniscus, 12 - capsule of femorotibial joint, 13 - joint partition, $14-$ subextensor pouch, 15 - tendons of long digital extensor and third peroneal muscle, 16 - subpopliteal pouch, 17 - popliteal muscle, 18 - lateral collateral ligament, 19 - distal bursa of lateral collateral ligament, 20 - medial collateral ligament, 21 - distal bursa of medial collateral ligament, 22, 23 - anterior and posterior cruciate ligaments, 24 - longitudinal ligament of stifle, 25, 26 - articular cartilage of femoral trochlea and patella, 27 - capsule of femorotibial joint, 28 - middle patellar ligament, 29 - lateral patellar ligament, 30, 31 - its lateral and medial portions, 32 - bursa of biceps muscle of thigh, 33 - medial patellar ligament, 34 - femoropatellotibial ligament, 35 - infrapatellar fat body, 36 - femur, 37 tibia, 38 - patella, 39, popliteal artery, 40 - fatty tissue, 41 - third peroneal muscle. 
The posterior tibial ligament of the lateral meniscus (Figs. 11, 15, 16-9), the broadest and at the same time thinnest of the ligaments under discussion, arises from the posteroinferior edge of the meniscus and ends at the edge of the popliteal notch of the tibia, laterally to the terminal attachment of the posterior cruciate ligament.

The posterior tibial ligament of the medial meniscus (Fig. 11-10), covered by the posterior cruciate ligament from behind and by the medial portion of the longitudinal ligament of stifle from above (Fig. $11-24$ ), arises from the posterior end of the meniscus, runs forward and inward and ends in the posterior intercondylar area.

The femoral ligament of the lateral meniscus (Figs. 10, 11, 15, 16,-11) has it origin on the femur, at the height of the upper edge of its medial condyle. Hence it extends downwards and laterad towards the peripheral border of the lateral meniscus. It is the only ligament of those discussed that is connected with the fibrous membrane of the joint capsule.

All the ligaments of the menisci are characterized by the parallel and relatively loose arrangement of their fibres.

The capsule of the femorotibial joint (Figs. 8, 9, 10, 14, 15-12) is loose and comparatively thin. Its fibrous membrane is best developed on the posterior side of the joint, where it blends with the adventitia of the and virtually lacking in the front. In the youngest European bisons the fibrous membrane is attached along the line of the epiphyseal cartilages of the femur and tibia and to the peripheral edges of the menisci except the groove for the tendon of the popliteal muscle, impressed in the peripheral border of the lateral meniscus. In adults the attachments of this membrane are moved away from the margin of the joint by about $2-3 \mathrm{~cm}$ on the femur and coincide with these margins on the tibia.

The synovial membrane forms two sacs, a lateral and a medial, which, clinging to each other in a sagittal plane of the joint, constitute a partition of the joint (Fig. 10-13). The cavities of these sacs communicate with each other in 7 per cent of cases, and the chiefly in old bisons, by an aperture in the partition. The medial sac communicates with the femoropatellar joint cavity in all European bisons. The lateral sac forms two pouches and a synovial bursa. Its subextensor pouch (Figs. 8, 13-14) has the shape of an elongate drop and underlies the common tendon of the long digital extensor and third peroneal muscles in the groove for muscles in the tibia. Measured from the margin of the articular surface of the tibia, this pouch hangs for a distance of $4 \mathrm{~cm}$ in the youngest European bisons and $7-8 \mathrm{~cm}$ in the oldest specimens. The other pouch of the lateral sac of the joint under description is the subpopliteal pouch (Figs. 8, 13, 15-16), which extends under the tendon of origin of the popliteal muscle (Figs. 13, 15, 16-17). The third structure of the 
Table 8

Dimensions of collateral ligaments of femorotibial joint and cruciate ligaments of stifle joint (in $\mathrm{mm}$ ). $\mathrm{L}-\mathrm{length}$, $\mathrm{W}$ - width, $\mathrm{T}$ - thickness.

\begin{tabular}{|c|c|c|c|c|c|c|c|c|c|c|c|c|c|c|}
\hline \multirow{3}{*}{ Group } & \multirow{3}{*}{$\mathrm{n}$} & \multicolumn{7}{|c|}{ Collateral ligaments } & \multicolumn{6}{|c|}{ Cruciate ligaments } \\
\hline & & \multicolumn{3}{|c|}{ Lateral } & \multicolumn{4}{|c|}{ Medial } & \multicolumn{3}{|c|}{ Anterior } & \multicolumn{3}{|c|}{ Posterior } \\
\hline & & $\mathrm{L}$ & W & $\mathrm{T}$ & v & L & W & $\mathbf{T}$ & $\mathrm{L}$ & W & $\mathbf{T}$ & $\mathrm{L}$ & W & $\mathrm{T}$ \\
\hline \multicolumn{15}{|c|}{ Males } \\
\hline 0 & 8 & 49.0 & 6.9 & 1.2 & & 64.0 & 7.3 & 1.4 & 33.0 & 4.0 & 3.4 & 44.0 & 7.5 & 2.2 \\
\hline $\mathrm{I}$ & 5 & 540 & 7.3 & 1.8 & & 80.0 & 7.7 & 1.7 & 41.5 & 6.0 & 3.8 & 52.0 & 8.0 & 2.6 \\
\hline II & 11 & 78.0 & 12.7 & 3.4 & & 135.0 & 14.0 & 3.4 & 55.0 & 10.1 & 6.2 & 67.0 & 8.4 & 5.3 \\
\hline III & 8 & 82.0 & 17.5 & 3.7 & & 142.0 & 17.2 & 3.9 & 57.0 & 9.7 & 6.3 & 70.0 & 8.3 & 5.4 \\
\hline IV & 8 & 86.0 & 17.6 & 4.2 & & 140.0 & 17.1 & 4.4 & 55.0 & 9.9 & 6.3 & 68.0 & 8.4 & 5.5 \\
\hline $\mathrm{V}$ & 7 & 88.0 & 18.1 & 4.4 & & 142.0 & 17.0 & 4.7 & 50.0 & 9.8 & 6.1 & 65.0 & 8.2 & 5.0 \\
\hline G.C. & & 1.91 & 2.62 & 3.67 & & 2.22 & 2.33 & 3.36 & 1.52 & 2.45 & 1.79 & 1.48 & 1.09 & 2.27 \\
\hline \multicolumn{15}{|c|}{ Females } \\
\hline 0 & 4 & 43.0 & 6.3 & 1.2 & & 60.0 & 7.2 & 1.2 & 28.0 & 3.8 & 3.2 & 42.2 & 5.8 & 2.2 \\
\hline I & 1 & 63.0 & 6.5 & 1.5 & & 86.0 & 9.0 & 0.8 & 39.0 & 6.0 & 4.0 & 46.0 & 6.1 & 3.0 \\
\hline II & 6 & 65.0 & 9.5 & 3.3 & & 90.0 & 13.2 & 2.5 & 42.0 & 7.2 & 4.6 & 56.0 & 5.8 & 4.7 \\
\hline III & 1 & 84.0 & 13.5 & 3.5 & & 129.0 & 12.8 & 2.8 & 44.0 & 7.0 & 3.5 & 55.0 & 6.4 & 5.0 \\
\hline IV & 3 & 74.0 & 15.3 & 3.8 & & 120.0 & 15.0 & 3.5 & ' 42.0 & 7.3 & 4.7 & 57.0 & 6.0 & 4.7 \\
\hline V & 9 & 79.0 & 15.9 & 4.0 & & 123.0 & 15.1 & 4.0 & 42.0 & 8.0 & 5.2 & 58.0 & 6.1 & 4.8 \\
\hline G.C. & & 1.82 & 2.52 & 3.33 & & 2.06 & 2.10 & 3.33 & 1.53 & 2.11 & 1.66 & 1.37 & 1.05 & 2.18 \\
\hline
\end{tabular}


lateral sac is the proximal synovial bursa of the lateral collateral ligament of the femoropatellar joint (Figs. 13, 15-6). This bursa separates the ligament from the substratum, i.e. the tendon of origin of the popliteal muscle.

\section{Ligaments of the Femorotibial Joint}

The lateral collateral ligament (Figs. 11, 12, 13, 15, 16-18) arises from the fossa for its attachment on the femur. The deep portion of this ligament ends on the lateral surface of the tibial condyle and its superficial portion passes finally into the fibrous band of the leg, constituting its superficial layer (Fig. 17-2). The distal synovial bursa of this ligament (Fig. 13-19) is autonomous.

The medial collateral ligament (Figs. 11, 12, 14, 15, 16-20) runs from the fossa of its attachment on the medial side of the femur to the tibia, where its attachment forms a line parallel to the long axis of this bone. This ligament has only a distal synovial bursa (Fig. 14-21).

The collateral ligaments of the femorotibial joint are loosely connected with the articular capsule and menisci. The medial ligament can be particularly easily displaced in a sagittal plane. The measurements of these ligaments are given in Table 8.

The anterior cruciate ligament (Figs. 9, 10, 11-22) arises from the intercondylar fossa of the femur and extends forward and downward. Above the posterior intercondylar area of the tibia it reveals a tendency to split into a lateral and a medial part. Crossing the posterior cruciate ligament on the lateral side it turns right by $90^{\circ}$ round its long axis and thus its medial portion becomes a superficial layer and the lateral portion a deep one. The superficial layer runs to the front above the attachment of the anterior tibial ligament of the lateral meniscus on the tibia and ends in the anterior intercondylar area. The deep layer reaches the anterior part of the central intercondylar area and terminates posteriorly to the attachment of the above-mentioned ligament of the lateral meniscus.

The posterior cruciate ligament (Figs. 9, 10, 11, 15, 16-23) goes away obliquely from the anteromedial part of the intercondylar fossa of the femur. It extends backwards, clinging closely to the floor of this fossa, which, being a semicylinder, constitutes a sort of pulley for it. The ligament ends flattened at the edge of the popliteal notch of the tibia, partly overlapped by the femoral ligament of the lateral meniscus. The measurements of the cruciate ligaments are given in Table 8.

The longitudinal ligament of the stifle (Fig. 11-24), which is a thin structure $(7 \mathrm{~mm}$ wide and $1 \mathrm{~mm}$ thick in adults), extonds antero-poste- 
Table 9

Dimensions of trochlea of femur (in $\mathrm{mm}$ and degrees). G.C. - growth coefficient, W. - width.

\begin{tabular}{|c|c|c|c|c|c|c|c|c|c|c|}
\hline \multirow{2}{*}{$\begin{array}{l}\text { Group, } \\
\text { name }\end{array}$} & \multirow{2}{*}{$\mathrm{n}$} & \multicolumn{3}{|c|}{ W. proximal } & \multicolumn{3}{|c|}{ W. distal } & \multicolumn{3}{|c|}{$\begin{array}{c}\text { Angle of trochlear } \\
\text { ridges }\end{array}$} \\
\hline & & $\overline{\mathbf{x}}$ & s & $\mathrm{v}$ & $\overline{\mathbf{x}}$ & $\mathbf{s}$ & $\mathbf{v}$ & $\overline{\mathrm{x}}$ & $\mathbf{s}$ & $\mathrm{v}$ \\
\hline \multicolumn{11}{|c|}{ European bison, males } \\
\hline 0 & 8 & 27.2 & 4.4 & 16.2 & 24.3 & 3.6 & 14.8 & 4.0 & 2.3 & 57.5 \\
\hline I & 5 & 35.6 & 5.8 & 16.3 & 30.8 & 4.7 & 15.2 & 4.4 & 1.9 & 43.5 \\
\hline II & 16 & 55.0 & 4.6 & 8.4 & 41.1 & 3.5 & 8.5 & 9.8 & 1.4 & 14.2 \\
\hline III & 17 & 58.6 & 3.2 & 5.5 & 44.4 & 3.5 & 7.9 & 9.3 & 1.0 & 10.7 \\
\hline IV & 15 & 61.1 & 3.3 & 5.4 & 45.1 & 2.2 & 4.9 & 10.2 & 1.6 & 15.7 \\
\hline V & 13 & 60.5 & 2.8 & 4.6 & 44.8 & 1.4 & 3.1 & 9.5 & 1.7 & 17.9 \\
\hline G. C. & & 2.22 & & & 1.8 & & & 2.37 & & \\
\hline \multicolumn{11}{|c|}{ European bison, females } \\
\hline 0 & 4 & 24.0 & & & 21.7 & & & 2.8 & & \\
\hline I & 1 & 35.5 & & & 31.5 & & & 1.7 & & \\
\hline II & 9 & 46.1 & 4.1 & 8.9 & 35.8 & 4.2 & 11.7 & 8.5 & 1.9 & 22.3 \\
\hline III & 6 & 51.0 & 1.0 & 0.2 & 39.0 & 1.0 & 2.6 & 9.1 & 0.5 & 5.5 \\
\hline IV & 7 & 51.0 & 1.4 & 2.7 & 39.2 & 2.0 & 5.1 & 8.3 & 1.7 & 20.4 \\
\hline $\mathrm{V}$ & 18 & 55.2 & 4.7 & 8.5 & 41.2 & 4.2 & 10.2 & 9.5 & 1.5 & 15.7 \\
\hline G. C. & & 2.80 & & & 1.90 & & & 3.42 & & \\
\hline \multicolumn{11}{|c|}{ American bison, females } \\
\hline & 4 & 49.7 & & & 40.4 & & & 9.2 & & \\
\hline \multicolumn{11}{|c|}{ European bison - American bison hybrids, male } \\
\hline & 1 & 62.0 & & & 46.8 & & & 9.4 & & \\
\hline \multicolumn{11}{|c|}{ European bison-domestic cattle hybrids, females } \\
\hline Fest & & 55.0 & & & 48.0 & & & 11.7 & & \\
\hline Felon & & 62.0 & & & 49.0 & & & 8.3 & & \\
\hline Fellach & & 68.0 & & & 54.0 & & & 8.8 & & \\
\hline Festyn & & 68.0 & & & 54.0 & & & 8.8 & & \\
\hline Fey & & 63.0 & & & 47.0 & $\cdot$ & & 10.3 & & \\
\hline \multicolumn{11}{|c|}{ European bison-domestic cattle hybrids, females } \\
\hline Felly & & 60.0 & & & 45.0 & & & 11.7 & & \\
\hline Fela & & 62.0 & & & 49.0 & & & 9.3 & & \\
\hline Fama & & 56.0 & & & 43.0 & & & 9.3 & & \\
\hline \multicolumn{11}{|c|}{ Domestic cattle, males } \\
\hline & 2 & 70.0 & & & 59.0 & & & 6.6 & & \\
\hline \multicolumn{11}{|c|}{ Domestic cattle, females } \\
\hline & 10 & 53.9 & 4.5 & 8.3 & 43.6 & 4.5 & 10.3 & 7.8 & 1.4 & 18.1 \\
\hline \multicolumn{11}{|c|}{ Watussi cattle, male } \\
\hline & 1 & 55.0 & & & 43.8 & & & 8.1 & & \\
\hline \multicolumn{11}{|c|}{ Watussi cattle, female } \\
\hline & 1 & 50.8 & & & 43.8 & & & 5.5 & & \\
\hline \multicolumn{11}{|c|}{ Bubalus bubalus, male } \\
\hline & 1 & 56.0 & & & 39.4 & & & 11.8 & & \\
\hline \multicolumn{11}{|c|}{ Zebu, female } \\
\hline & 1 & 46.5 & & & 38.0 & & & 6.5 & & \\
\hline \multicolumn{11}{|c|}{ Yak, female } \\
\hline & 1 & 37.5 & & & 34.8 & & & 3.5 & & \\
\hline
\end{tabular}


ricrly. It is situated between the lamellae of the joint partition. It arises, together with the superficial layer of the anterior cruciate ligament, from the tibia. Passing to the rear, it divides into two unequal bands, which end at the edge of the popliteal notch of the tibia.

\subsection{Femoropatellar Joint}

In its structure and function the trochlea of the femur of the European bison combines elements of a technical pulley, wedge and screw. Its proximal width exceeds the distal one, and the same is true of the growth coefficients of these widths (Table 9). In consequence, the planes in which the trochlear ridges lie cross below the stifle, forming a dihedral angle, the size of which is slight in foetuses and newborns and discernible without the necessity of measuring in adults (Table 9). The chord or length of the lateral ridge is smaller than that of the medial. The growth coefficient of the chord is greater for the medial ridge (Table 10). The radius of the medial ridge is greater than that of the lateral and so is its growth coefficient. The angle of the curvature is always larger in the lateral ridge. The difference between these parameters increases with age (Table 10). The femoral trochlea is deflected laterally by an angle of $75^{\circ}$ in group 0 , this angle being $69^{\circ}$ in adults (Fig. 7). Over its extent from the top downwards, the articular surface of the trochlea undergoes a $38^{\circ}$ torsion towards the medial side.

The articular cartilage of the femoral trochlea (Figs. 8, 9, 10-25) blends with the epiphyseal cartilage in young specimens. It covers the articular surface of the trochlea and also a small area of its medial surface. Beyond the medial ridge it passes into the articular cartilage to the medial condyle of the femur. Its thickness on the ridges is considerable, ranging from 5.0 to $9.0 \mathrm{~mm}$ in groups 0 and $\mathrm{I}$ in males and from 2.8 to $7.3 \mathrm{~mm}$ in these groups in females. In adult bisons of both sexes it is $1.3-1.9 \mathrm{~mm}$.

The articular surface of the patella, together with the fibrocartilage of the patella arising from it, constitutes a partly elastic exact cast of the femoral trochlea. The thickness of the articular cartilage (Figs. 8, 9, 10 -26) ranges from 2.9 to $4.3 \mathrm{~mm}$ in males of groups 0 and $\mathrm{I}$ and from 2.0 to $2.6 \mathrm{~mm}$ in females of these groups. In adults of both sexes it is $1.3-2.1 \mathrm{~mm}$. It is characterized by great individual variation.

The fibrocartilage of the patella is in the form of a lamella inclined towards the trochlea. In adult European bisons its thickness is up to $3 \mathrm{~cm}$. Inferiorly it passes into the medial patellar ligament (Figs. 11, 12, 14-33).

The capsule of the femoropatellar joint (Figs. 8, 9, 10, 12, 13, 14, 15-27) is virtually represented by the synovial membrane. This capsule 
is attached to the articular edges of both bone components of this joint. On the medial side it passes into the capsule of the femorotibial joint. As a whole, it is a roomy, loose, excessively developed sac. Above the patella this excess manifests itself as a blunt pouch directed upwards, the length of which approximates that of the patella, whereas below the patella the capsule develops two swells on the lateral side and one on the medial (Figs. 12, 14-27). The synovial membrane of the femoropatellar joint is characterized by very great accumulations of villi and fclds. Their largest numbers occur in the region of the apex of the patella and at its base. The villi are hair-shaped and $1-6 \mathrm{~cm}$ long in adults. The height of folds reaches $3 \mathrm{~cm}$.

The total capacity of the cavity of the femoropatellar joint and the medial sac of the femorotibial joint averages $80 \mathrm{ml}$ in foetuses and newborns, $125 \mathrm{ml}$ in calves of group I, $225 \mathrm{ml}$ in adult males and $180 \mathrm{ml}$ in adult females. The amount of synovial fluid obtained from this common cavity is up to $14 \mathrm{ml}$ in adult males and $9 \mathrm{ml}$ in adult females. The capacity of the lateral sac of the femorotibial joint is $16 \mathrm{ml}$ in group 0 and $70 \mathrm{ml}$ in group I of both sexes and, respectively, 100 and $80 \mathrm{ml}$ in adult males and females.

\section{Ligaments of the Femoropatellar Joint}

The middle patellar ligament (Figs. $8,9,10,11,12,14-28$ ) is a band, uniform in width, directly underlying the fascia of the stifle. It is a downward continuation of both the tendon of the rectus muscle of the thigh and the medial portion of the lateral vastus muscle. Out of the ligaments of the patella the middle patellar is the only one that has no connections with the joint capsule, since it is separated from it by the infrapatellar fat body, in which it carves a suitable groove. On the tibia it crosses the attachment of the lateral patellar ligament. A spacious infrapatellar bursa, 36 by $45 \mathrm{~mm}$ in adults, occurs under the insertion of the middle patellar ligament.

The lateral patellar ligament (Figs. 8, 9, 11, 12, 13, 14-29) extends at an angle of $30^{\circ}$, pointing downwards, to the previous ligament. It is in the form of a trapezium oriented with its shorter base down and consists of two portions, a lateral (Fig. 12-30) and a medial (Fig. 12-31). The lateral portion is the extension of the tendon of the anterior part of the femoral biceps muscle. The medial portion, arising from the side edge of the patella, is somewhat wider than a half of the width of the lateral portion. Under the unpaired part of this ligament is the spacious subtendinous bursa of the biceps muscle (Fig. 13-32), its iapacity being $3-4 \mathrm{ml}$ in the youngest specimens and $40-50 \mathrm{ml}$ in adults. The lateral patellar ligament blends with the subextensor pouch of the capsule of the femorotibial joint. 


\section{Fibrous Band of the Leg}

The fibrous band of the leg (Fig. 17) is considered to be a remnant of the shaft of the fibula. It is set among appropriate muscles of this region. Proximally it is divided into two layers, a superficial (Fig. 17-2), which is a downward prolongation of the lateral collateral ligament of
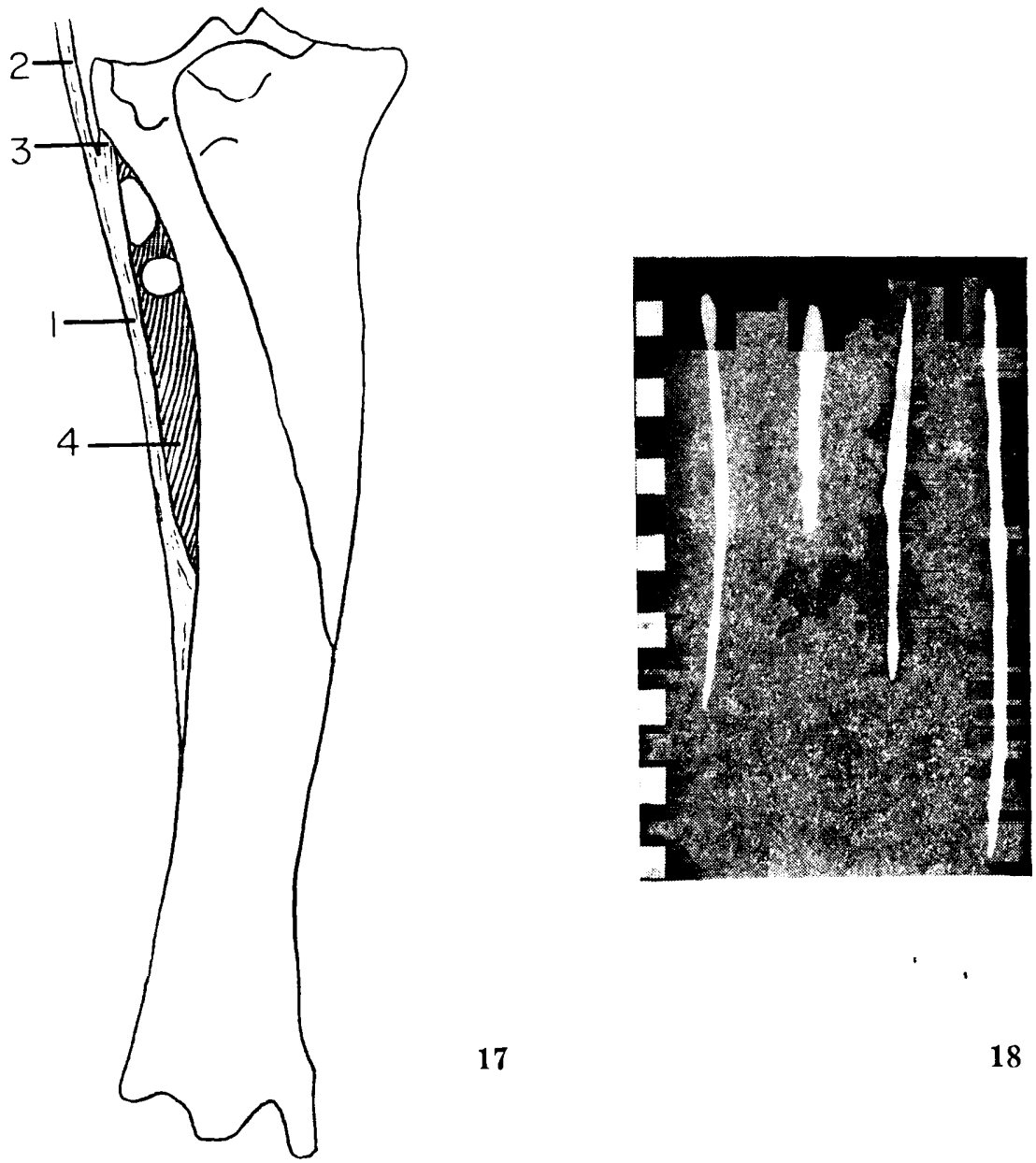

Fig. 17. Fibrous band of leg.

1 - fibrous band of leg, 2 - its superficial layer (lateral collateral ligament of femorotibial joint), 3 - deep layer, 4 - interosseous membrane of leg.

Fig. 18. Vestigial fibulae. From left to right, three fibulae of 8-, 10- and 15-year-old male European bisons, the fourth one of an adult male buffalo.

the femorotibial joint, and'a deep (Fig. 17-3), which arises from the tibia, in the place where its fibular process is present in domestic cattle. The uniform band ends on the lateral surface of the tibia, in the distal third of this bone. The interosseous space of the leg, occurring between 
this band and the tibia, is filled with the thin interosseous membrane of the leg (Fig. 17-4), in which there are two interosseous foramina.

The presence of the vestigial shaft of the fibula in the band (Fig. 18) in 15 per cent of the E.uropean bisons belonging to groups III $-\mathrm{V}$ is a notably individual character.

\section{Hock Joint}

\section{Intertarsal Joints}

Tarsocrural joint. The concave articular surface of the cochlea of the tibia is described with the same radius at the corresponding ridges of the proximal trochlea of the tibial tarsal articulating with it (Table 12). The angle of the curvature of the articular grooves of the cochlea is smaller than that of the ridges of the proximal trochlea of the tibial tarsal corresponding with them by about $65^{\circ}$, which constitutes the flexionextension range of the movements in this joint. The thickness of the articular cartilage of the cochlea is strikingly small compared with the
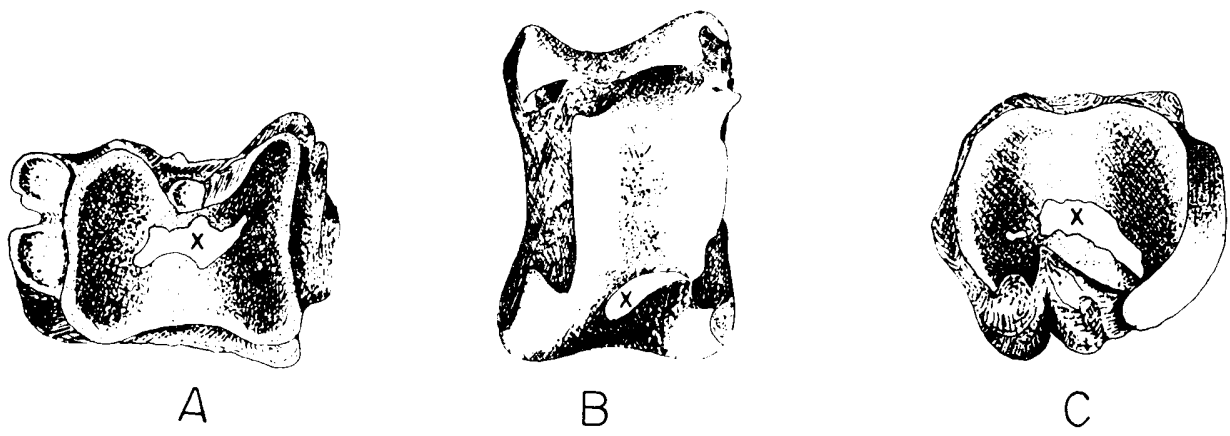

Fig. 19. Synovial fossae $(x)$ on the articular surfaces of the hock joint. A - articular surface of tibial cochlea, B - articular surface of tibial tarsal bone, C - articular surface of $T c+T I V$.

thickness of this cartilage in other joints. It is $1.1 \mathrm{~mm}$ in groups 0 and I and only $0.1-0.2 \mathrm{~mm}$ in older groups.

A characteristic morphological detail of this cartilage of the tibial cochlea in all European bisons is the presence of a synovial fossa in it (Fig. $19 \mathrm{~A}-\mathrm{x}$ ). In adult bisons it is visible also on digested bones, which indicates that the defect affects not only the cartilaginous tissue but the bone as well. In foetuses and newborns the future area of this fossa is manifested as a place coated with a very thin light-brown connectivetissue membrane, which peripherally passes into articular cartilage. As regards several-month-old calves, the membrane is already missing and the bottom of the fossa is of rough osseous tissue with numerous nutrient 
foramina scattered all over it. In the youngest and oldest males the length of the fossa is 15 and $25 \mathrm{~mm}$, respectively, and the width 7 and $10 \mathrm{~mm}$. In the youngest and oldest females this length is correspondingly 12 and $22 \mathrm{~mm}$ and the width 6 and $10 \mathrm{~mm}$. The depth of the fossa is approximately twice as great as the thickness of the surrounding articular cartilage.

The proximal trochlea of the tibial tarsal has two sagittal ridges unequal in breadth. The lateral ridge is broader and therefore blunter than the medial one. The angles of the curvatures of both trochlear ridges are given in Table 12. The angle is smaller in the lateral ridge. In respect of other parameters the ridges resemble each other (Table 12). The articular cartilage of the proximal trochlea of the tibial tarsal is $1.6 \mathrm{~mm}$ thick in the youngest groups and $0.3 \mathrm{~mm}$ in the oldest ones.

The tarsocrural joint co-forms the calcaneomalleolar joint, situated laterallly, which in its general outlines is similar to this joint in domestic cattle.

Proximal intertarsal joint. The ridges of the distal trochlea of the tibial tarsal bone have smaller chords and radii but larger angles of curvature than have those of the proximal trochlea of this bone (Table 12).

The articular cartilage of the distal trochlea passes on to the posterior surface of the tibial tarsal, where it participates in the formation of the proximal talocalcaneal joint. It also passes from the cartilage of the distal talocalcaneal joint. In the place where this cartilage passes on to the posterior surface of the bone there is a noticeable synovial fossa (Fig. $19 \mathrm{~B}-\mathrm{x}$ ), the development and morphological characters of which are similar to those described for the synovial fossa of the cochlea of the tibia. Its length is $4 \mathrm{~mm}$ and the width $3 \mathrm{~mm}$ in the youngest bisons and, respectively, 32 and $8 \mathrm{~mm}$ in the oldest specimens.

Medially, the proximal articular surface of the fused central and fourth tarsal bones $(T c+T I V)$ is the negative impression of the distal trochlea of the tibial tarsal only that the angle of its curvature is smaller than the angle of the curvature of the trochlear ridges by about $95^{\circ}$. Thus, theoretically this difference is the flexion-extension range of movements in the proximal intertarsal joint. The synovial fossa on the proximal articular surface of the $T c+T I V$ (Fig. $19 \mathrm{C}-\mathrm{x}$ ) is a remnant of the syndesmosis between the central and fourth tarsal bones, which occurs in foetuses and newborns. The cartilage in the proximal intertarsal joint is $1.6 \mathrm{~mm}$ thick in the youngest specimens and $0.3 \mathrm{~mm}$ in the oldest ones.

The distal intertarsal and tarsometatarsal joints are plane joints, resembling those of domestic cattle in structure. Their articular cartilage 
is about $1.3 \mathrm{~mm}$ thick in the youngest European bisons and $0.2-0.3 \mathrm{~mm}$ in the oldest.

Intratarsal joints. The proximal and distal talocalcaneal joints are of the greatest functional-motor importance. The cavity of the proximal talocalcaneal joint between the posterior surface of the tibial tarsal and the adjoining surface of the fibular tarsal forms a perfect arc, the angular value of which is $75^{\circ}$ in all European bisons. The gliding fibular tarsal bone moves over a distance having an angular value of $30^{\circ}$. The distal talocalcaneal joint is an arthrodia.

The sides and the plantar surface of the capsule of the hock joint is made of a fibrous membrane which here develops strong colateral and plantar ligaments. Only on the anterior side and in the angle formed by the tibia and the body of the fibular tarsal bone the fibrous membrane is thin and relatively loose.

This fibrous membrane is common to all the tarsal joints mentioned. The synovial membrane is attached to the margins of the articular surfaces of the respective bone components. Moreover, it wraps the interosseous ligaments and the long peroneal muscle tendon, which runs transversely in the cavity of the tarsometatarsal joint towards its insertion. The synovial membrane, in addition, encloses the artery supplying the tibial tarsal bone and extending in the cavity of the proximal talocalcaneal joint.

On the anterior side the capsule of the hock joint forms two swellings. The lateral swelling (Fig. 24-1) is visible between the lateral digital extensor tendon (Fig. 24-51) and the long digital extensor tendon (Fig. 24-50). The smaller medial swelling (Figs. 22, 24-2) is situated between the third peroneal muscle tendon (Figs. 22, 24-47) and the anterior edge of the medial collateral ligament (Figs. 22, 24-12-13).

In the angle formed by the tibia and the body of the fibular tarsal the capsule of the hock joint pouches halfway up the body of the fibular tarsal (Fig. 22-3). The synovial membrane of the pouch bears villi.

The synovial membrane of the hock joint comprises 5 articular cavities. The first and roomiest of them is common to the tarsocrural, proximal intertarsal, and proximal and distal talocalcaneal joints. The second cavity is that of the distal intertarsal joint. The tarsometatarsal joint has the next three cavities. One of them occurs between the first tarsal and the fused third and fourth metatarsal bones and the other two, separated from each other by the canal of the long peroneal muscle, belong to the remaining part of the tarsometatarsal joint.

The cavity of the joint between $T I$ and $M t I I I+I V$ has not a communication with the joint formed by the vestigial $M t I I$ and $M t I I I+I V$, although their close vicinity would suggest its presence. 
The greatest capacity, and so measurable, is that of the first joint cavity. In foetuses and newborns it is $24-36 \mathrm{ml}$, in calves up to one year of age $35-45 \mathrm{ml}$, in adult males $50-60 \mathrm{ml}$ and in adult females about $50 \mathrm{ml}$. The other four joint cavities are fisures, the capacity of which does not exceed $1 \mathrm{ml}$ each in adults.

\section{Ligaments of the Hock Joint}

Lateral side. In European bisons the lateral collateral ligament (Figs. $20,24,25-4-8)$ is divided into 5 parts:

1. The tibiometatarsal part (Fig. 20-4) arises from the posterolateral surface of the distal end of the tibia and arches downwards. On its way it is attached to the malleolus of the fibular tarsal and Tc+TIV and terminates on $M t I I I+I V$. The insertion tendon of the long peroneal muscle (Figs. 20, 24-48) penetrates under the anterior border of the tibiometatarsal part at the height of the tarsometatarsal joint. The anterior border of this part overlaps the calcaneometatarsal part of the ligament under discussion (Fig. 20-6) in adulth bisons, with which it may be coalesced.

2. The calcaneomalleolar part (Fig. 20-5) is another, deeper lying, portion of this ligament. It arises anteriorly to the attachment of the previous part on the malleolus and above it on the tibia. It ends attached to a special rough area on the lateral side of the fibular tarsal bone.

3. The calcaneometatarsal part (Fig. 20-6) begins on the lateral surface of the fibular tarsal bone, below the insertion of the calcaneomalleolar part, and ends on $M t I I I+I V$, posteriorly to the tibiometatarsal part.

4. The tibiocalcaneal part (Figs. 20, 24, 25-7) is the third, counting from the outer side, layer of the ligament. It arises anteriorly on the tibia, below the proximal annular ligament (Figs. 20, 22, 24-35) and has a multiplanar spiral course. It runs inferolateroposteriorly and is attached to the fibular tarsal bone, above the calcaneomalleolar part.

5. The talomalleolar part (Fig. 20-8) originates at the posterior edge of the malleolus and runs the shortest way to the fossa for attachment of the ligament on this side of the proximal trochlea of the tibial tarsal bone. The dimensions of individual parts of the lateral collateral iigament are given in Table 13.

The lateral talometatarsal ligament (Fig. 21, 25-9) begins in its fossa for attachment on the lateral side of the distal trochlea of the tibial tarsal and ends on $M t I I I+I V$. In old European bisons it grows together with the calcaneometatarsal ligament, which is posterior to it. This last ligament (Fig. 21, 25-10) arises on the coracoid process of the fibular tarsal bone and terminates on the anterolateral aspect of $M t I I I+I V$.

The lateral ligament connecting Tc $+T I V$ with $M t I I I+I V$ (Fig. 21-11) 
Table 13

Dimensions of lateral collateral ligament of hock joint (in $\mathrm{mm}$ ).

$\mathrm{L}$ - lenght, $\mathrm{W}$ - width, $\mathrm{T}$ - thickness.

\begin{tabular}{|c|c|c|c|c|c|c|c|c|c|c|c|c|c|c|c|c|}
\hline \multirow[t]{2}{*}{ Group } & \multirow[t]{2}{*}{$\mathrm{n}$} & \multicolumn{3}{|c|}{$\begin{array}{l}\text { Tibiometatarsal } \\
\text { part }\end{array}$} & \multicolumn{3}{|c|}{$\begin{array}{l}\text { Calcaneomalleolar } \\
\text { part }\end{array}$} & \multicolumn{3}{|c|}{$\begin{array}{c}\text { Calcaneometatarsal } \\
\text { part }\end{array}$} & \multicolumn{3}{|c|}{$\begin{array}{l}\text { Tibiocalcanean } \\
\text { part }\end{array}$} & \multicolumn{3}{|c|}{$\begin{array}{c}\text { Talomalleolar } \\
\text { part }\end{array}$} \\
\hline & & $\mathrm{L}$ & W & $\mathbf{T}$ & $\mathrm{L}$ & W & $\mathrm{T}$ & $\mathrm{L}$ & $\mathrm{W}$ & $\mathrm{T}$ & I & W & $\mathrm{T}$ & $\mathbf{L}$ & $\mathrm{W}$ & $\mathrm{T}$ \\
\hline \multicolumn{17}{|c|}{ Males } \\
\hline 0 & 8 & 67.3 & 7.1 & 1.1 & 38.8 & 5.7 & 1.1 & 42.7 & 8.8 & 1.6 & 35.0 & 10.5 & 1.3 & 18.7 & 8.3 & 1.6 \\
\hline I & 5 & 94.0 & 6.6 & 1.6 & 40.7 & 9.5 & 1.3 & 57.0 & 8.7 & 1.7 & 44.3 & 10.1 & 2.3 & 14.7 & 11.3 & 2.5 \\
\hline II & 11 & 105.1 & 9.6 & 2.6 & 55.9 & 10.6 & 2.0 & 74.0 & 12.4 & 3.2 & 55.0 & 14.6 & 3.0 & 18.4 & 13.9 & 3.7 \\
\hline III & 8 & 113.0 & 12.4 & 3.6 & 54.1 & 12.3 & 2.9 & 76.8 & 13.3 & 3.5 & 61.3 & 15.2 & 3.6 & 20.0 & 13.9 & 4.3 \\
\hline IV & 8 & 116.6 & 12.5 & 4.3 & 55.8 & 12.3 & 3.4 & 77.4 & 13.9 & 3.8 & 61.1 & 15.1 & 4.6 & 20.2 & 13.6 & 4.6 \\
\hline V & 7 & 117.4 & 12.3 & 4.8 & 53.4 & 12.3 & 4.0 & 77.3 & 13.6 & 4.0 & 65.1 & 15.4 & 4.5 & 19.5 & 12.9 & 4.8 \\
\hline G.C. & & 1.74 & 1.74 & 4.36 & 1.40 & 2.16 & 3.04 & $1.8 \%$ & 1.54 & 2.50 & 1.86 & 1.47 & 3.46 & 1.42 & 1.55 & 3.00 \\
\hline \multicolumn{17}{|c|}{ Females } \\
\hline 0 & 4 & 66.2 & 5.8 & 1.1 & 36.8 & 5.2 & 1.0 & 37.5 & 8.1 & 1.4 & 33.7 & 9.9 & 1.2 & 12.0 & 7.8 & 1.5 \\
\hline I & 1 & 72.0 & 6.2 & 1.4 & 38.0 & 6.6 & 1.7 & 48.0 & 8.8 & 1.8 & 45.0 & 11.0 & 2.5 & 13.2 & 10.2 & 1.8 \\
\hline II & 6 & 98.5 & 8.0 & 2.0 & 42.0 & 8.7 & 1.4 & 54.5 & 10.0 & 2.7 & 49.2 & 12.8 & 2.7 & 17.0 & 12.5 & 2.5 \\
\hline III & 1 & 113.0 & 9.6 & 2.8 & 51.0 & 9.0 & 2.0 & 60.0 & 13.5 & 2.5 & 55.0 & 12.0 & 3.5 & 18.0 & 13.0 & 3.0 \\
\hline IV & 3 & 107.7 & 10.5 & 3.4 & 51.0 & 10.7 & 2.9 & 63.0 & 12.8 & 3.0 & 58.0 & 13.7 & 3.8 & 18.3 & 12.6 & 3.6 \\
\hline V & 9 & 112.8 & 10.8 & 3.7 & 50.8 & 10.8 & 3.6 & 72.6 & 12.4 & 3.3 & 57.0 & 14.2 & 3.9 & 18.4 & 12.9 & 3.7 \\
\hline G.C. & & 1.70 & 1.86 & 3.37 & 1.38 & 2.10 & 3.60 & 1.95 & 1.54 & 2.36 & 1.69 & 1.43 & 3.25 & 1.53 & 1.65 & 2.47 \\
\hline
\end{tabular}




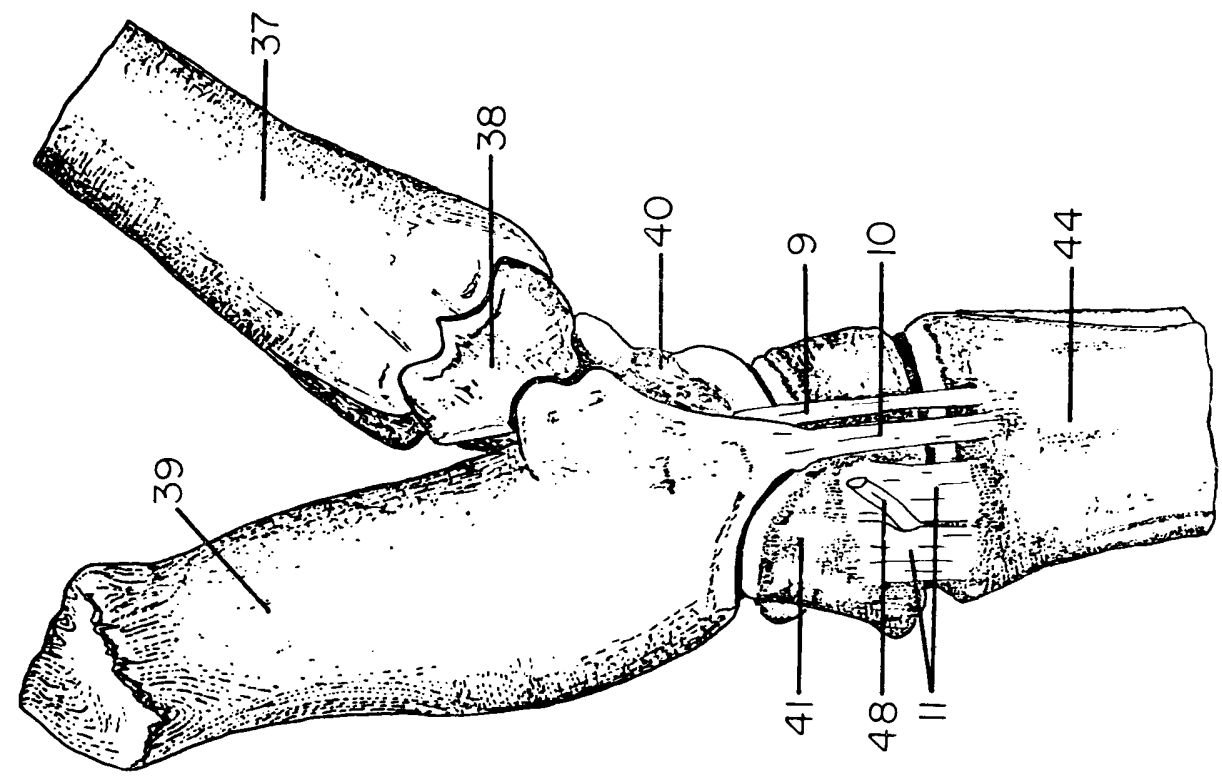

จิ

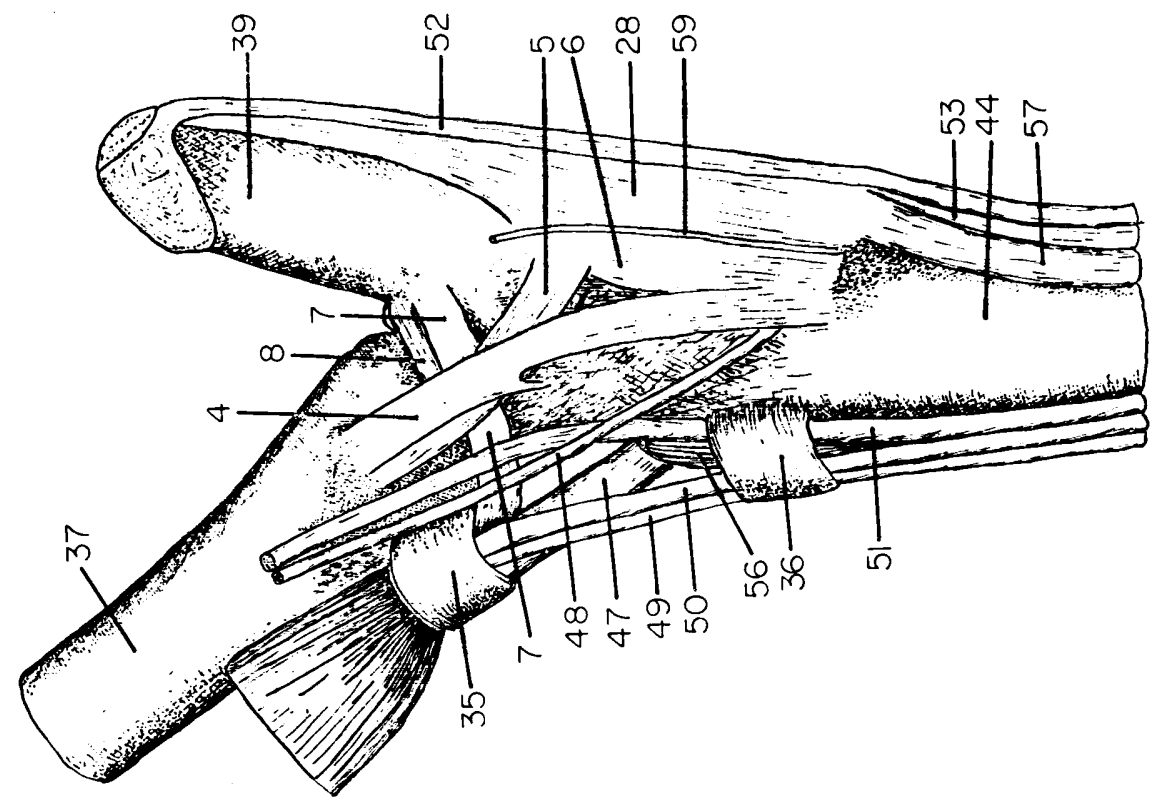

Fig. 20. Left hock joint with its capsule partly removed. Lateral riew. Superficial layer (14-year-old male).

Fig. 21. Right hock joint with its capsule removed. Lateral view. Deep layer (8-year-old male). 


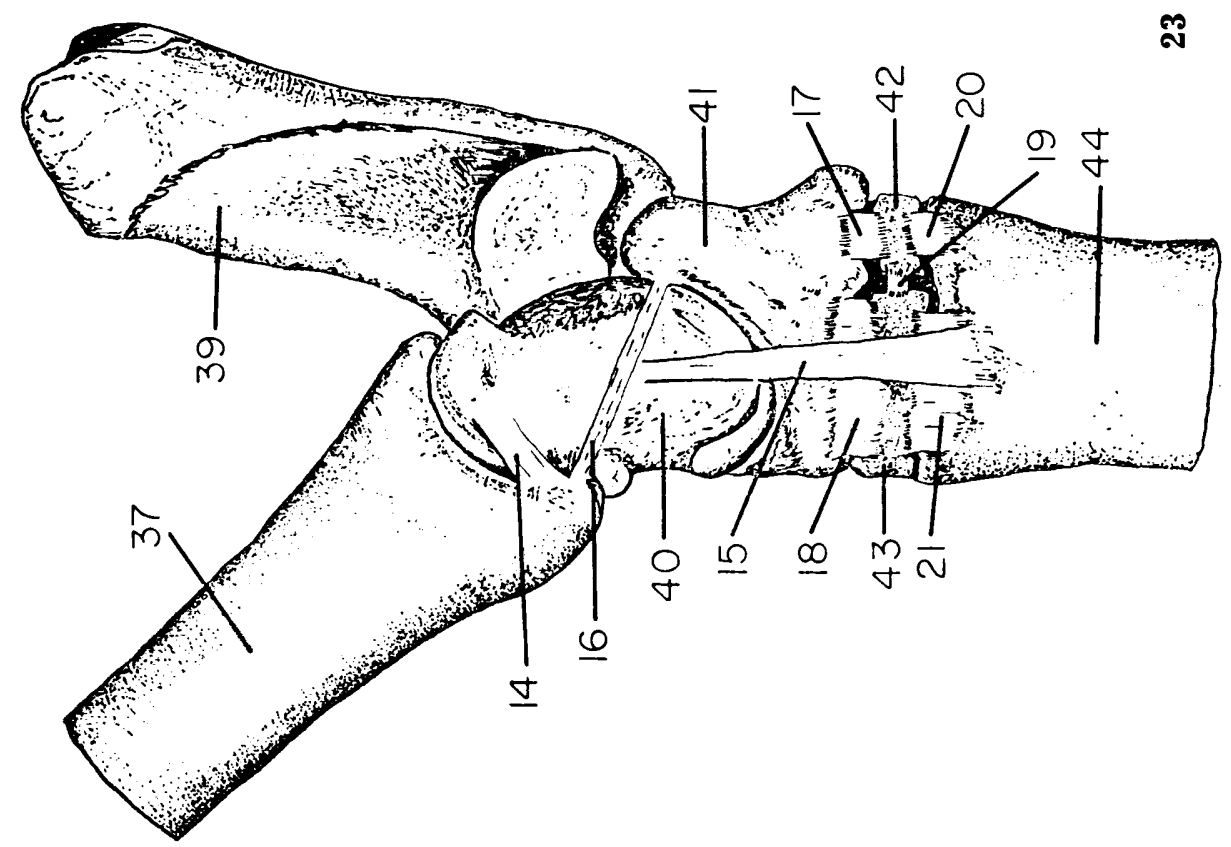

ฟ

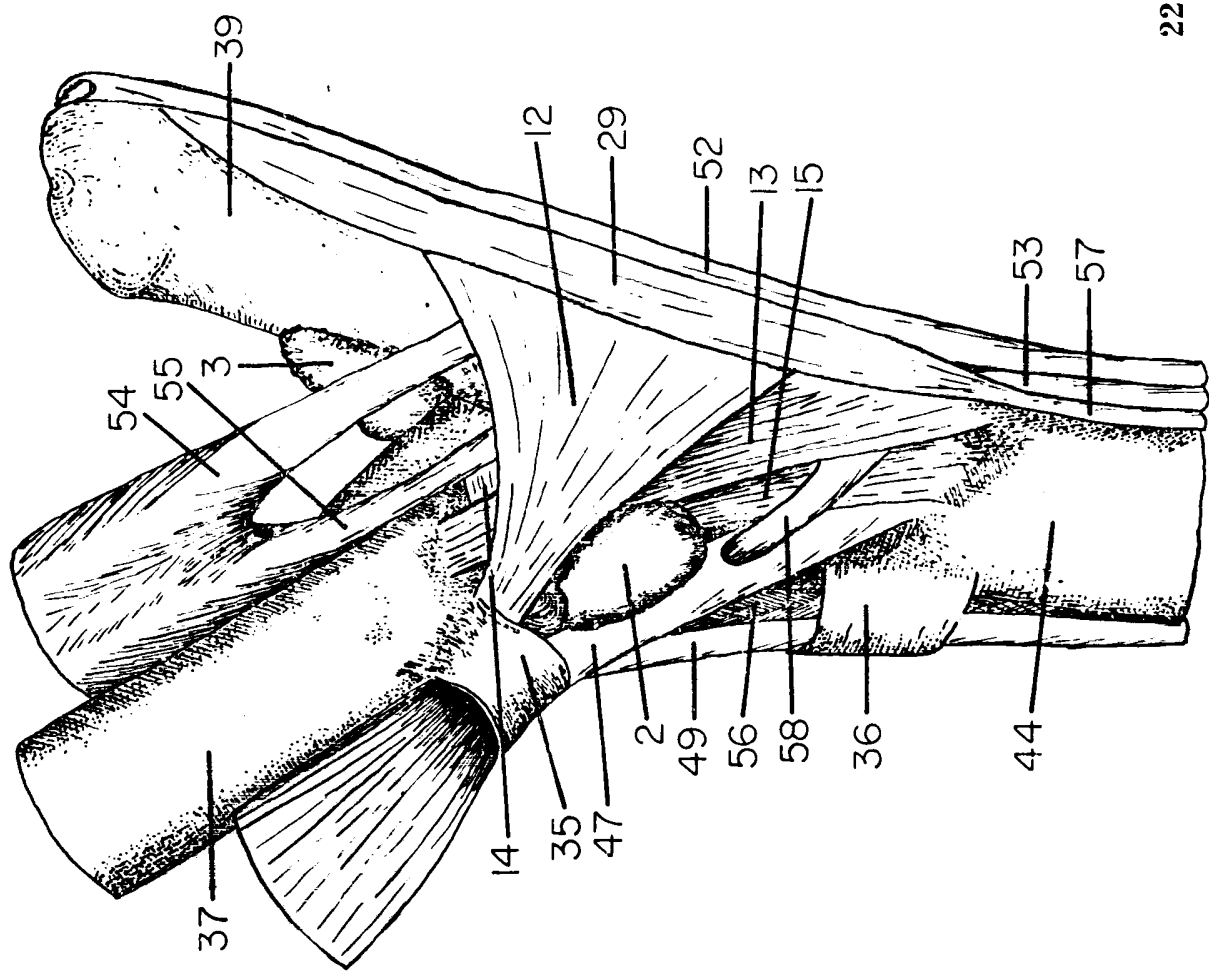

Fig. 22. Right hock joint. Medial view. Superficial layer (14-year-old male).

Fig. 23. Right hock joint with its capsule removed. Medial view. Deep layer (8-year-old male). 

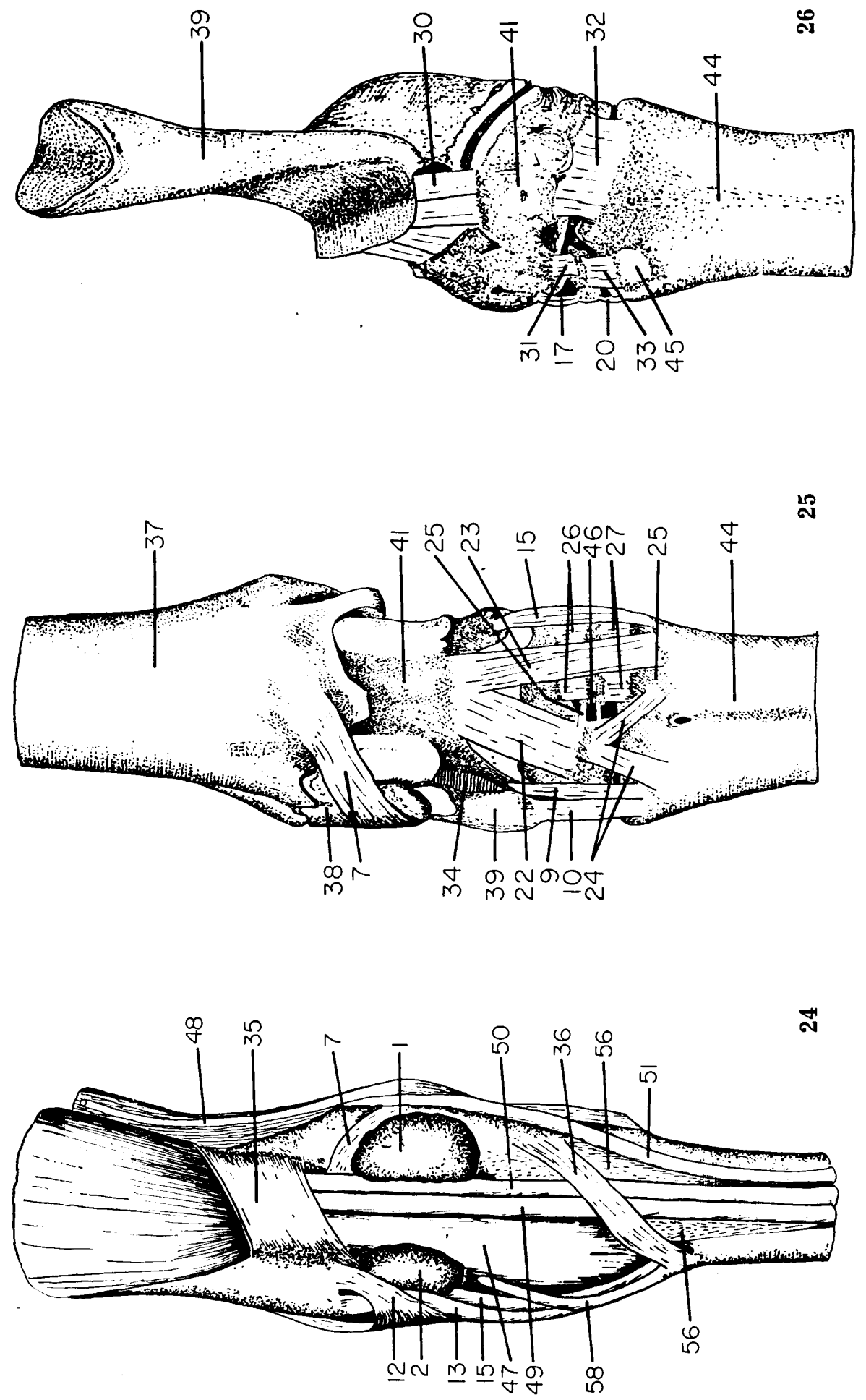
is divided into two parts, an anterior and a posterior, separated by the tendon of the long peroneal muscle (Fig. 21-48), which squeezes in between them.

Medial side. The medial collateral ligament (Figs. 22, 23, 24-12-14) splits into three parts in European bisons:

1. The part connecting the tibia with the fibular tarsal and Tc+TIV (pars tibiocalcaneocentroquartalis - Figs. 22, 24-12) has the shape of a trapezium with its longer (distal) base against the long plantar ligament (Fig. 22-29). This part begins on the anteromedial surface of the distal end of the tibia and terminates on the sustentaculum of the fibular tarsal bone and $T c+T I V$, exchanging fibres with the long plantar ligament.

2. The tibiometatarsal part (Figs. 22, 24-13) extends obliquely under the previous part. It arises from the distal end of the tibia and on its way is attached in turn to Tc $+T I V, T I I+T I I I$ and $T I$ to end on $M t I I I+I V$. Its anterior border and the medial talometatarsal ligament (Figs. 22, 23, $24,25-15)$ coalesce by the medium of loose fibres, and the posterior border blends with the long plantar ligament (Fig. 22-29).

3 . The tibiotalar part, (Figs. 22, 23-14) is the third and deepest portion of the ligament concerned. It begins on the posterior edge of a special

Fig. 24. Left hock joint. Anterior view. Superficial layer (14-year-old male). Fig. 25. Right hock joint with its capsule removed. Anterior view. Deep layer (14-year-old male).

Fig. 26. Right hock joint with its capsule removed. Posterior (plantar) view. Deep layer (8-year-old male).

(In Figs. 22 and 24 the joint capsules are filled with gelatin), 1, 2 - lateral and medial swellings of joint capsule, 3 - pouch of joint capsule, 4-8 - lateral collateral ligament, 4 - tibiometatarsal part, 5 calcaneomalleolar part, 6 - calcaneometatarsal part, 7 - tibiocalcanean part, 8 - talomalleolar part, 9 - lateral talometatarsal ligament, 10 - calcaneometatarsal ligament, 11 - lateral centroquartometatarsal ligament, 12-14 - medial collateral ligament, 12 - tibiocalcaneocentroquartal part, 13 - tibiometatarsal part, 14 - tibiotalar part, 15 - medial talometatarsal ligament, 16-21 - ligaments of the medial side connecting: 16 tibia with $T c+I V, 17-T c+T I V$ with $T I, 18-T c+T I V$ with $T I I+T I I I, 19-$ $T I$ with $T I I+T I I I, 20-T I$ with $M I I I I+I V, 21-T I I+T I I I, 22-27$ - ligaments of the anterior side connecting: $22-T t$ with $T c+T I V, 23-T t$ with $M t I I I+I V, 24-$ $T c+T I V$ with $M t I I I+I V, 25-T I I+T I I I$ with $T c+I V$, (intratarsal), $26-T I I+T I I I$ with $T c+T I V$ (intertarsal), $27-T I I+T I I I$ with $M t I I I+I V, 28,29-$ lateral and medial parts of long plantar ligament, $30-33-$ ligaments of the plantar side connecting: $30-T f$ with Tc + TIV, $31-T c+T I V$ with TI, $32-T c+T I V$ with $M t I I I+I V, 34$ - interosseous talocalcaneal ligament, 35, 36 - proximal and distal annular ligaments, 37 - tibia, 38 - malleolus, 39 - fibular tarsal bone, 40 - tibial tarsal bone, $41-T c+T I V, 42-T I, 43-T I I+T I I I, 44-M t I I I+I V, 45-$ surface for articulation with MtII, 46 - tarsal canal, 47 - tendon of third peroneal muscle, 48 - tendon of long peroneal muscle, 49 - tendon of extensor muscle of digit III, 50 - tendon of long extensor muscle of digits, 51 - tendon of extensor muscle of digit $I V, 52$ - tendon of superficial flexor muscle of digits, 53 - tendon of deep flexor muscle of digits, 54 - tendon of long flexor muscle of great toe and posterior tibial muscle, 55 - tendon of long flexor muscle of digits, 56 - short extensor muscle of digits, 57 - middle interosseous muscle, 58 - anterior tibial muscle, 59 - lateral plantar vein. 
process of the tibia, and ends in the fossa for attachment on this side of the proximal trochlea of the tibial tarsal bone. The dimensions of the medial collateral ligament are included in Table 14.

The medial talometatarsal ligament (Figs. 22, 23, 24, 25-15) is an autonomous tape-like structure. It arises from its fossa for attachment on this side of the distal trochlea of the tibial tarsal bone and ends on $M t I I I+I V$.

After the removal of the ligaments described above, the ligaments that connect the following bones appear on the medial side: the tibia with Tc + TIV (Fig. 23-16), Tc + TIV with TI (Figs. 23, 26-17), Tc+TIV with

\section{Table 14}

Dimensions of medial collateral ligament of hock joint (in $\mathrm{mm}$ ).

$\mathrm{L}-$ length, $\mathrm{W}-$ width, $\mathrm{T}-$ thickness

\begin{tabular}{|c|c|c|c|c|c|c|c|c|c|c|c|}
\hline \multirow{3}{*}{ Group } & \multirow{3}{*}{$\mathrm{n}$} & \multicolumn{4}{|c|}{$\begin{array}{l}\text { Part connecting tibia } \\
\text { with } T c+T I V \text { and } T f\end{array}$} & \multicolumn{3}{|c|}{$\begin{array}{c}\text { Tibiometatarsal } \\
\text { part }\end{array}$} & \multicolumn{3}{|c|}{ Tibiotalar part } \\
\hline & & \multirow[b]{2}{*}{$\mathrm{L}$} & \multicolumn{2}{|c|}{ Width } & \multirow[b]{2}{*}{$\mathbf{T}$} & \multirow[b]{2}{*}{$\mathrm{L}$} & \multirow[b]{2}{*}{$\mathrm{W}$} & \multirow[b]{2}{*}{$\mathrm{T}$} & \multirow[b]{2}{*}{$\mathrm{L}$} & \multirow[b]{2}{*}{$\mathrm{w}$} & \multirow[b]{2}{*}{$\mathrm{T}$} \\
\hline & & & $\overline{\text { prox. }}$ & dist. & & & & & & & \\
\hline \multicolumn{12}{|c|}{ Males } \\
\hline 0 & 8 & 51.0 & 9.0 & 26.5 & 2.1 & 52.8 & 5.4 & 1.9 & 18.8 & 11.6 & 1.1 \\
\hline I & 5 & 62.0 & 11.3 & 40.0 & 2.7 & 75.3 & 5.5 & 1.9 & 17.7 & 11.0 & 2.2 \\
\hline II & 11 & 70.0 & 14.3 & 47.3 & 3.8 & 86.3 & 7.5 & 2.7 & 29.2 & 13.1 & 2.7 \\
\hline III & 8 & 74.5 & 18.4 & 48.1 & 5.6 & 82.2 & 8.0 & 3.6 & 33.3 & 14.3 & 3.1 \\
\hline IV & 8 & 79.7 & 19.0 & 44.7 & 8.0 & 83.7 & 9.0 & 3.7 & 32.0 & 13.9 & 4.1 \\
\hline V & 7 & 83.6 & 18.7 & 47.8 & 8.0 & 85.6 & 9.3 & 3.9 & 31.3 & 14.0 & 4.1 \\
\hline G. C. & & 1.64 & 2.08 & 1.84 & 3.81 & 1.62 & 1.72 & 2.05 & 1.67 & 1.21 & 3.73 \\
\hline \multicolumn{12}{|c|}{ Females } \\
\hline 0 & 4 & 46.8 & 8.7 & 23.8 & 1.7 & 47.7 & 5.3 & 1.8 & 16.0 & 9.7 & 1.0 \\
\hline I & 1 & 56.0 & 9.0 & 35.0 & 2.0 & 60.0 & 6.0 & 2.3 & 16.0 & 11.0 & 2.0 \\
\hline II & 6 & 66.0 & 12.1 & 42.5 & 3.6 & 67.5 & 7.2 & 2.2 & 25.4 & 13.8 & 2.2 \\
\hline III & 1 & 80.0 & 14.0 & 40.0 & 4.8 & 65.0 & 7.5 & 2.4 & 26.0 & 12.0 & 2.0 \\
\hline IV & 3 & 70.3 & 14.7 & 44.7 & 6.8 & 65.3 & 7.2 & 3.1 & 27.3 & 12.0 & 2.5 \\
\hline $\mathrm{V}$ & 9 & 76.0 & 15.8 & 41.9 & 6.1 & 73.9 & 8.0 & 3.0 & 27.8 & 12.6 & 3.0 \\
\hline G. C. & & 1.62 & 1.82 & 1.76 & 3.59 & 1.55 & 1.50 & 1.67 & 1.74 & 1.24 & 3.00 \\
\hline
\end{tabular}

TII+TIII (Fig. 23-18), TI with TII+TIII (Fig. 23-19), TI with $M i I I+I V$ (Figs. 23, 26-20), TII+TIII with MtIII+IV (Fig. 23-21).

Anterior side. The removal of the short extensor muscle of the digits in European bisons (Figs. 20, 22, 24-56) uncovers the poorly developed dorsal tarsal ligaments connecting the following bones: $T t$ with Tc+TIV (Fig. 25-22), $T t$ with $M t I I I+I V$ (Fig. 25-23), Tc+TIV with $M t I I I+I V$ (Fig. 25-24), $T I I+T I I I$ with $T c+I V$ (intratarsal - Fig. 25-25), $T I I+T I I I$ with Tc+TIV (intertarsal - Fig. 25-26), TII + TIII with MtIII +IV (Fig. $25-27)$. 
Posterior (plantar) side. The long plantar ligament consists of a lateral and a medial part joined by a middle sheet. These three elements remain distinct only in foetuses and newborns, whereas in adult European bisons they exchange fibres with each other.

The lateral part (Fig. 20-28) begins over the whole length of the posterolateral border of the fibular tarsal bone, being initially united with the middle sheet. Further towards the digits it separates from this last and at the height of the sustentaculum tali is divided into an anterior and a posterior portion. The anterior portion is attached to the posterolateral surface of $T c+T I V$, its anterior margin being grown together with the calcaneometatarsal part of the lateral collateral ligament and terminates on $M t I I I+I V$ between the attachment of this ligament and the middle interosseous muscle, running in this place. The posterior portion runs perpendicularly, is attached to $T c+T I V$ and a special tubercle on this side of the proximal end of $M t I I I+I V$ and next merges with the superficial part of the middle interosseous muscle.

The medial part of the long plantar ligament (Fig. 22-29), much stronger than the lateral part, passes from the tuberosity and body of the fibular tarsal bone on to the posteromedial border of the sustentaculum tali and next on to Tc+TIV, thus forming two bridges over the passages for appropriate tendons of the deep flexor muscle of the digits. In its further course the medial part splits into an anterior and a posterior portion. The anterior portion runs on to the posteromedial surface of $T c+T I V$, where it is attached, next reaches $T I I+T I I I$ and ends on this side on $M t I I I+I V$. At the height of $T c+T I V$ the posterior portion is divided into an anterior and a posterior branch, the first of which ends on $M t I I I+I V$. The posterior branch behaves analogously to the posterior portion of the lateral part of the ligament being described.

The middle sheet becomes thinner inferiorly and ends in a sharp semilunar margin, from under which the tendon of the deep flexor muscle of the digits emerges. The tendon of the superficial flexor muscle of the digits is contiguous to the posterior surface of this sheet.

The removal of the long plantar ligament and middle interosseous muscle detects the ligaments connecting the following bones on the plantar side of the hock joint: $T f$ with Tc+TIV (Fig. 26-30), Tc+TIV with TI (Fig. 26-31), Tc+TIV with MtIII+IV (Fi $\overrightarrow{5}$. 26-32), TI with $M t I I I+I V$ (Fig. 26-33).

\section{Interosseous Ligaments of the Hock Joint}

The interosseous talocalcaneal ligament (Fig. 25-34) of European bisons is a strong structure extending transversely in the tarsal sinus. 
Table 15

Dimensions of articular surfaces of medial metatarsophalangeal joint (in $\mathrm{mm}$ and degrees).

\begin{tabular}{|c|c|c|c|c|c|c|c|c|c|c|c|c|c|c|c|}
\hline \multirow{4}{*}{ Group } & \multirow{4}{*}{$\mathrm{n}$} & \multicolumn{7}{|c|}{ Medial trochlea of $M t I I I+I V$} & \multirow{2}{*}{\multicolumn{6}{|c|}{$\begin{array}{l}\text { Proximal articular surface } \\
\text { of proximal phalanx }\end{array}$}} & \multirow{4}{*}{$\begin{array}{c}\text { Range } \\
\text { of move } \\
\text { ments } \\
\begin{array}{c}\bar{x}_{1}-\bar{x}_{2} \\
\bar{x}\end{array}\end{array}$} \\
\hline & & \multirow{2}{*}{\multicolumn{3}{|c|}{$\begin{array}{l}\text { Length } \\
\text { (chord) }\end{array}$}} & \multicolumn{4}{|c|}{ Curvature } & & & & & & & \\
\hline & & & & & \multirow{2}{*}{$\begin{array}{l}r \\
\overline{\mathrm{x}}_{1} \\
\end{array}$} & \multicolumn{3}{|c|}{ Angle } & \multicolumn{3}{|c|}{ Length (chord) } & \multicolumn{3}{|c|}{ Angle } & \\
\hline & & $\overline{\mathrm{x}}$ & $\mathrm{s}$ & $\mathrm{v}$ & & $\overline{\mathbf{x}}$ & $\mathbf{v}$ & $\mathbf{s}$ & $\overline{\mathrm{x}}$ & s & $\mathrm{v}$ & $\overline{\mathbf{x}}$ & $\mathrm{v}$ & $\mathrm{s}$ & \\
\hline \multicolumn{16}{|c|}{ Males } \\
\hline 0 & 8 & 23.0 & 2.8 & 12.2 & 11.9 & 211 & 4.5 & 2.1 & 21.0 & 1.2 & 5.7 & 87 & 4.3 & 4.9 & 124 \\
\hline I & 5 & 31.4 & 3.4 & 10.8 & 16.3 & 212 & 4.1 & 1.9 & 21.6 & 1.7 & 7.9 & 83 & 4.9 & 5.9 & 129 \\
\hline II & 16 & 40.3 & 1.9 & 4.7 & 20.6 & 204 & 4.0 & 2.0 & 29.7 & 1.7 & 5.7 & 93 & 5.8 & 6.2 & 111 \\
\hline III & 17 & 40.1 & 2.0 & 5.0 & 20.7 & 209 & 5.7 & 2.7 & 30.5 & 1.2 & 3.9 & 95 & 4.0 & 4.2 & 114 \\
\hline IV & 15 & 41.9 & 1.8 & 4.3 & 21.9 & 213 & 5.9 & 2.8 & 31.5 & 0.0 & 0.0 & 92 & 5.6 & 6.1 & 121 \\
\hline V & 13 & 41.9 & 1.7 & 4.1 & 21.5 & 207 & 3.6 & 1.7 & 31.7 & 1.0 & 3.2 & 94 & 5.2 & 5.5 & 114 \\
\hline G.C. & & 1.82 & & & 1.81 & 0.98 & & & 1.51 & & & 1.08 & & & 0.91 \\
\hline \multicolumn{16}{|c|}{ Females } \\
\hline 0 & 4 & 21.2 & & & 11.0 & 212 & & & 19.4 & & & 82 & & & 130 \\
\hline $\mathrm{I}$ & 1 & 33.0 & & & 17.3 & 215 & & & 21.0 & & & 86 & & & 129 \\
\hline II & 9 & 37.5 & 2.1 & 5.6 & 18.0 & 200 & 4.2 & 2.1 & 25.8 & 1.6 & 6.2 & 86 & 3.7 & 4.3 & 114 \\
\hline III & 6 & 38.5 & 2.3 & 6.0 & 20.0 & 211 & 4.8 & 2.3 & 28.3 & 1.4 & 4.9 & 92 & 4.3 & 4.7 & 118 \\
\hline IV & 7 & 38.3 & 1.4 & 3.6 & 19.6 & 205 & 4.2 & 2.0 & 27.9 & 1.0 & 3.6 & 91 & 1.5 & 1.6 & 114 \\
\hline V & 18 & 37.6 & 2.6 & 6.9 & 19.4 & 208 & 5.1 & 2.4 & 27.4 & 2.4 & 8.8 & 89 & 3.7 & 4.2 & 119 \\
\hline G.C. & & 1.77 & & & 1.76 & 0.98 & & & 1.41 & & & 1.08 & & & 0.90 \\
\hline
\end{tabular}


The other interosseous ligaments are small structures connecting the following bones: $T c+T I V$ with $M t I I I+I V$, Tc+TIV with $T I I+T I I I$, $T I I+T I I I$ with $T I, T I I+T I I I$ with $M t I I I+I V$ and $T I$ with $M t I I I+I V$.

\section{Metatarsophalangeal Joints}

The structure of two trochleae of the metatarsal bones is similar. The dimensions of the ridges of the medial trochlea are given in Table 15.

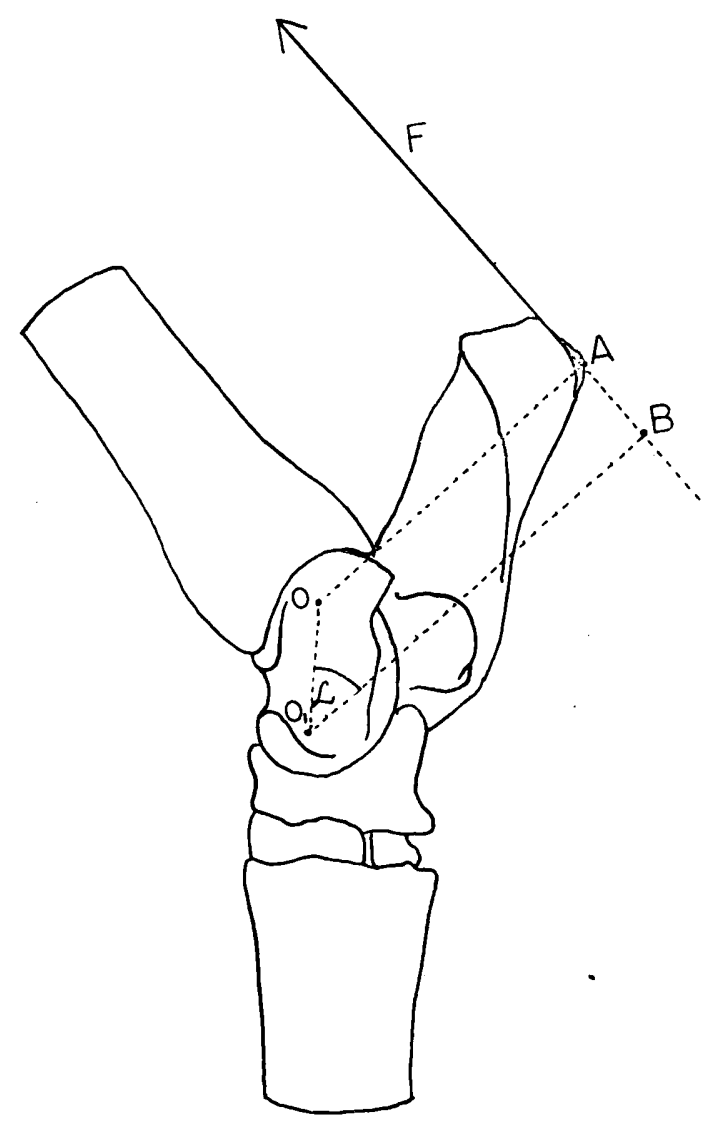

Fig. 27. System of extending forces of hock joint.

$F$ - force of extensors of hock joint, $O-$ axis of rotation of tarsocrural joint, $\mathrm{O}_{1}$ - axis of rotation of proximal intertarsal joint, $p(A O)$ - arm of extending force traced from centre $O, q\left(\mathrm{CO}_{1}\right)$ - arm of extending force traced from centre $\mathrm{O}_{1}, \alpha$ - angle of inclination of long axis of tibial tarsal bone to arms $p$ and $q$.

The articular cartilage which covers the articular surfaces of the trochleae is thin, $1.6-1.9 \mathrm{~mm}$ in the youngest specimens of both sexes and $0.2-0.5 \mathrm{~mm}$ in adults. Covering the working articular surfaces of the trochleae, it also passes on to their axial and abaxial surfaces, occupying small crescent areas. 
The proximal articular surfaces of the proximal phalanges are negative copies of the trochleae of the metatarsal bones, but the angles of their curvatures are smaller than those in the trochleae (Table 15). This difierence $\left(\bar{x}_{1}-\bar{x}_{2}\right)$ is at the same time the flexion-extension range of movements in the two metatarsophalangeal joints (Table 15).

The thickness of the articular cartilage on the articular surfaces of the proximal phalanges is similar to that of the cartilage of the trochleae.

In structure and arrangement the sesamoid bones of the proximal phalanges resemble those of domestic cattle.

In European bisons either metatarsophalangeal joint has its own joint capsule, but both capsules have their fibrous membrane in common. The attachment of this membrane coincides with the margins of the articular surfaces of particular bone components of the joints, except for the dorsal surface, where it is moved away to the outside from these edges by about $1 \mathrm{~cm}$. The attachment of the synovial membrane presents itself similarly.

The capsule of either of these joints forms two pouches. The dorsal pouch (Fig. 28-1) extends above the appropriate trochlea of the metatarsal bones and is $4 \mathrm{~cm}$ long in adult bisons. The plantar pouch (Fig. 28-2) squeezes in upwards between the portions of the deep part of the middle interosseous muscle and the metatarsal bones, being $3 \mathrm{~cm}$ long in the youngest specimens and $7-8 \mathrm{~cm}$ in adults of both sexes.

The synoviai membranes of both joints cling to each other in a sagittal plane and form a joint partition. In all European bisons this partition has an oval aperture, by which the cavities of these joints communicate with each other. The total capacity of both these cavities is $17 \mathrm{mi}$ in males of group $0,15 \mathrm{ml}$ in females of this group and up to $20 \mathrm{ml}$ in calves of both sexes up to 1 year of age. In adult males it ranges from 35 to $45 \mathrm{ml}$ and in adult females from 30 to $35 \mathrm{ml}$. The amount of synovial tluid obtained from both these cavities reaches $3 \mathrm{ml}$ in adults.

\section{Ligaments of the Metatarsophalangeal Joints}

The abaxial collateral ligament (Fig. 30-3) of European bisons consists of two portions, a superficial and a deep, which cross at an acute angle. The axial collateral ligament (Fig. $31-4$ ) is situated in the intertrochlear incisure of the metatarsal bones. It is in the form of a distally broadening lamina. Between the axial collateral ligaments of the two metatarsophalangeal joints there is a fissural space, through which the interdigital branch of the middle interosseous muscle passes (Figs. 31, 32-13).

\section{Sesamoidean Ligaments}

Proximal seamoidean ligaments. The proximal sesamoidean ligaments 
are appropriate portions of the middle interosseous muscle. In European bisons this muscle divides halfway down the metatarsus into a superficial and a deep part. The superficial part (Figs. 28, 30-5) is the downward extension of the fibres of the long plantar ligament and unlike the deep part has no muscle fibres. It splits into two portions, a lateral and a medial, which with the corresponding branches of the superficial flexor muscle of the digits form two tendinous sheaths (Figs. 30, 31, 32-6), which embrace the appropriate tendons of the deep digital flexor. The deep of the middle interosseous muscle (Figs. 29, 30, 31, 32-7-23) undergoes numerous divisions on its way down. Thus, at the distal third of the metatarsus it divides into lateral and medial abaxial portions (Figs. 30, 32-8, 9) and a middle sheet (Fig. 32-10). The sheet, in turn, splits into three branches, two of which are axial, a lateral (Fig. 32-11) and a medial (Figs. 31, 32-12), and the third - the interdigital branch (Figs. 31, 32-13) - is unpaired and lies between the axial branches.

The abaxial portions of the deep part of the middle interosseous muscle reach the abaxial and, partly, axial sesamoid bones. Above the sesamoid bones they send off the lateral and medial abaxial branches (Figs. 29, $30,32-14,15)$ to the external surfaces of the joints. These branches reach the dorsal surfaces of the middle phalanges, where most of their fibres terminate together with the medial and lateral digital extensor tendons. The other fibres of these branches, as the lateral and medial bands of the distal phalanges (Figs. 29, 30-16, 17), disappear in their periosteum. At the height of the metatarsophalangeal joints the abaxial portions give off the lateral and medial sesamoid bands (Figs. 30, 32-18, 19) to the external edges of the abaxial sesamoid bones.

The axial portions of the deep part of the muscle under study reach the axial and, externally, also abaxial sesamoid bones.

The interdigital branch of the muscle sheet goes under the interdigital intersesamoidean ligament (Figs. 31, 32-26) in the intertrochlear incisure, where it undergoes a strong lateral flattening. At this height it sends off some of its fibres (Fig. $31-20$ ) to the interdigital intersesamoidean ligament (Figs. 31, 32-26) and another bundle (Fig. 31-21) to the proximal interdigital ligament (Fig. 31-39). After sending off this last bundle of fibres, the interdigital branch divides into the lateral and medial axial twigs (Figs. 29,31,32-22, 23). These twigs pass on to the dorsal surfaces of the toes and end on the middle phalanges together with the corresponding medial and lateral digital extensors.

On the surfaces of the non-divided deep part of the middle interosseous muscle and on its longitudinal and transverse sections one can see muscle and on its longitudinal and transverse sections one can see muscle fibres embedded in the fibrous structure of this muscle. The number of muscle 

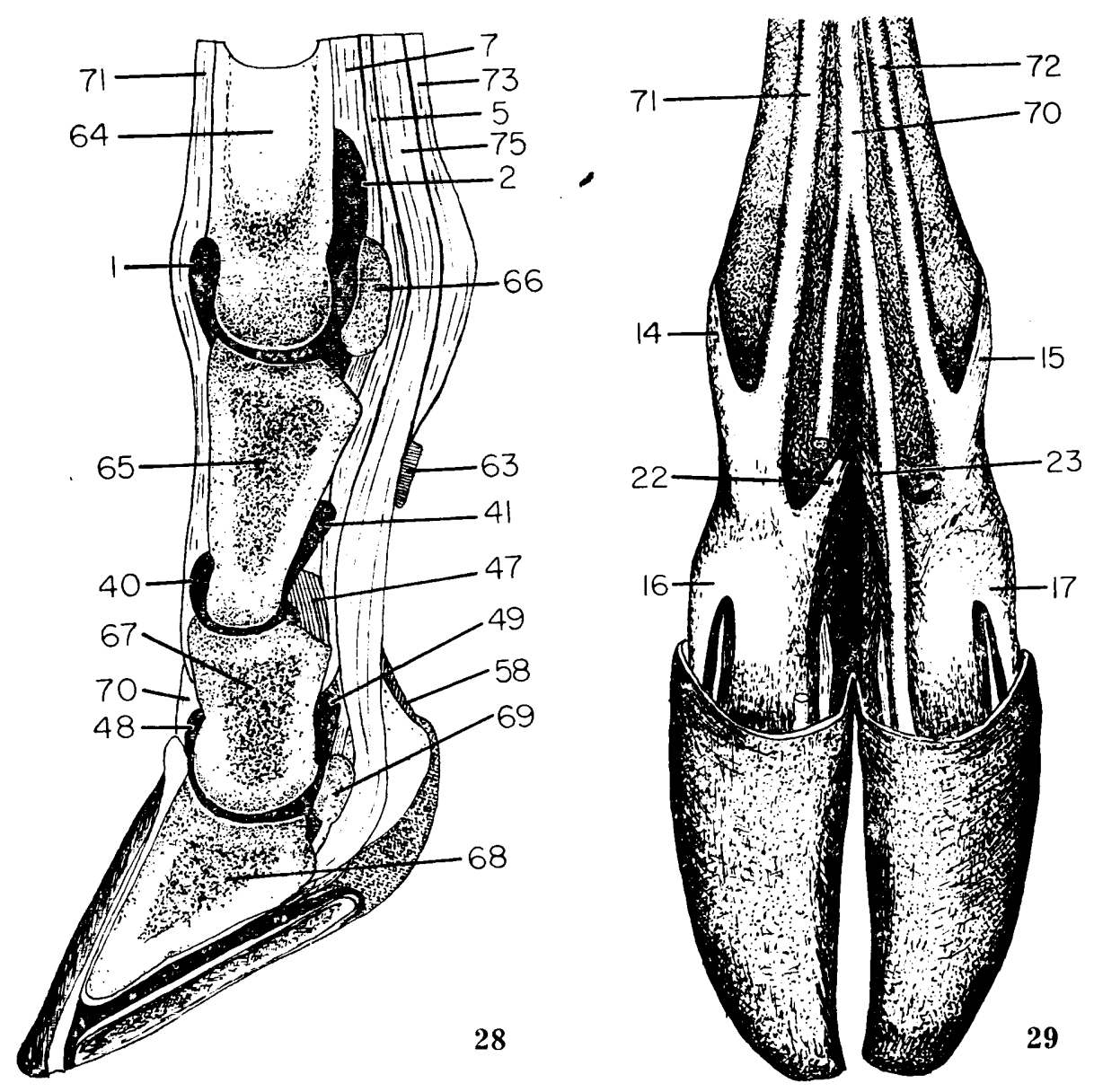

Fig. 28. Sagittal section through digit $I V$ of right hind-limb. Joint capsules of digits filled with gelatin (black) (8-year-old male).

Fig. 29. Digits of right hind-limb. Anterior view. (16-month-old male).

Explanation of Figs. 28-32.

1, 2 - dorsal and plantar pouches of capsule of metatarsophalangeal joint, 3, 4 abaxial and axial collateral ligaments of metatarsophalangeal joint, $5-23-$ middle interosseous muscle, 5 - superficial part, 6 - tendinous sheath of deep flexor muscle of digits, 7 - deep part, 8, 9 - lateral and medial abaxial portions, 10 middle sheet, 11, 12, 13 - lateral, medial and interdigital axial branches, 14, 15 lateral and medial abaxial branches, 16, 17 - lateral and medial bands for distal phalanx, 18, 19 - lateral and medial sesamoidean bands, 20,21 - fibres of interdigital branch to interdigital intersesamoidean and proximal interdigital ligaments, 22,23 - lateral and medial axial twigs, 24-26 - lateral, medial and interdigital intersesamoidean ligaments, 27, 28 - lateral and medial collateral sesamoidean ligaments, 29, 30 - lateral and medial abaxial oblique sesamoidean ligaments, 31, 32 - lateral and medial axial oblique sesamoidean ligaments, 33, 34 - lateral and medial abaxial cruciate sesamoidean ligaments, 35,36 - lateral and medial axial cruciate sesamoidean ligaments, 37,38 - lateral and medial phalangosesa- 


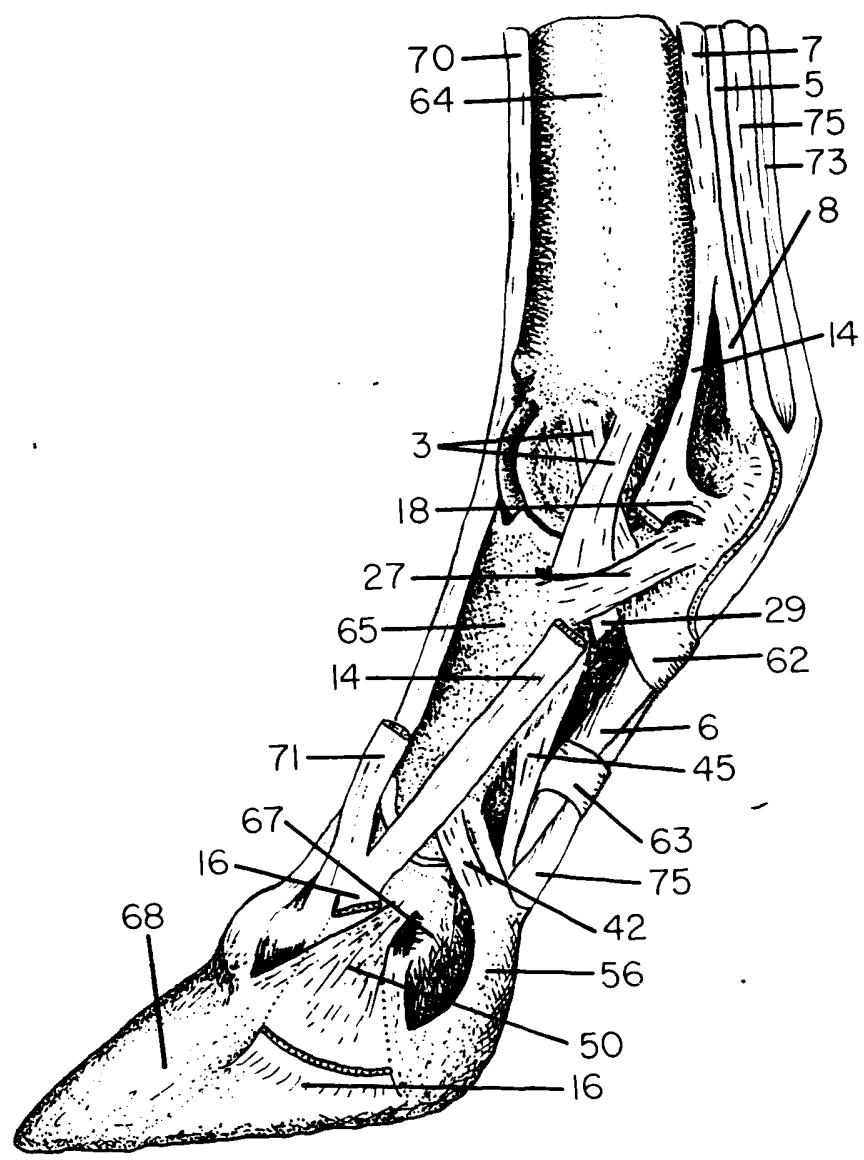

Fig. 30. Joints of digit IV in left hind-limb. Axial view (10-year-old male).

moidean ligaments, 39 - proximal interdigital ligament, 40,41 - dorsal and plantar pouches of capsule of proximal interphalangeal joint, 42,43 - abaxial and axial collateral ligaments of proximal interphalangeal joint, 44 - axial ligament of proximal and distal interphalangeal joints, 45-47- axial, abaxial and central plantar ligaments, 48, 49 - dorsal and plantar pouches of capsule of distal interphalangeal joint, 50, 51 - abaxial and axial collateral ligaments of distal interphalangeal joint, 52-55 - abaxial and axial ligaments attaching sesamoid bone of distal phalanx to middle and distal phalanges, 56-61 - distal interdigital ligament, 56, 57 - lateral and medial proximal branches, 58, 59 - lateral and medial middle branches, 60, 61 - lateral and medial distal branches, 62, 63 proximal and distal annular ligament, 64 - metatarsal bones III+IV $(M t I I I+I V)$, 65 - proximal phalanx, 66 - sesamoidean bone of proximal phalanx, 67,68 middle and distal phalanges, 69 - sesamoidean bone of distal phalanx, 70 - tendon of long extensor muscle of digits, 71 - tendon of extensor muscle of digit IV, 72 - tendon of extensor muscle of digit III, 73 - tendon of superficial flexor muscle of digits, 74 - its portion for digit III, 75 - tendon of deep flexor muscle of digits, 76, 77 - its portion digits $I V$ and $I I I$. 

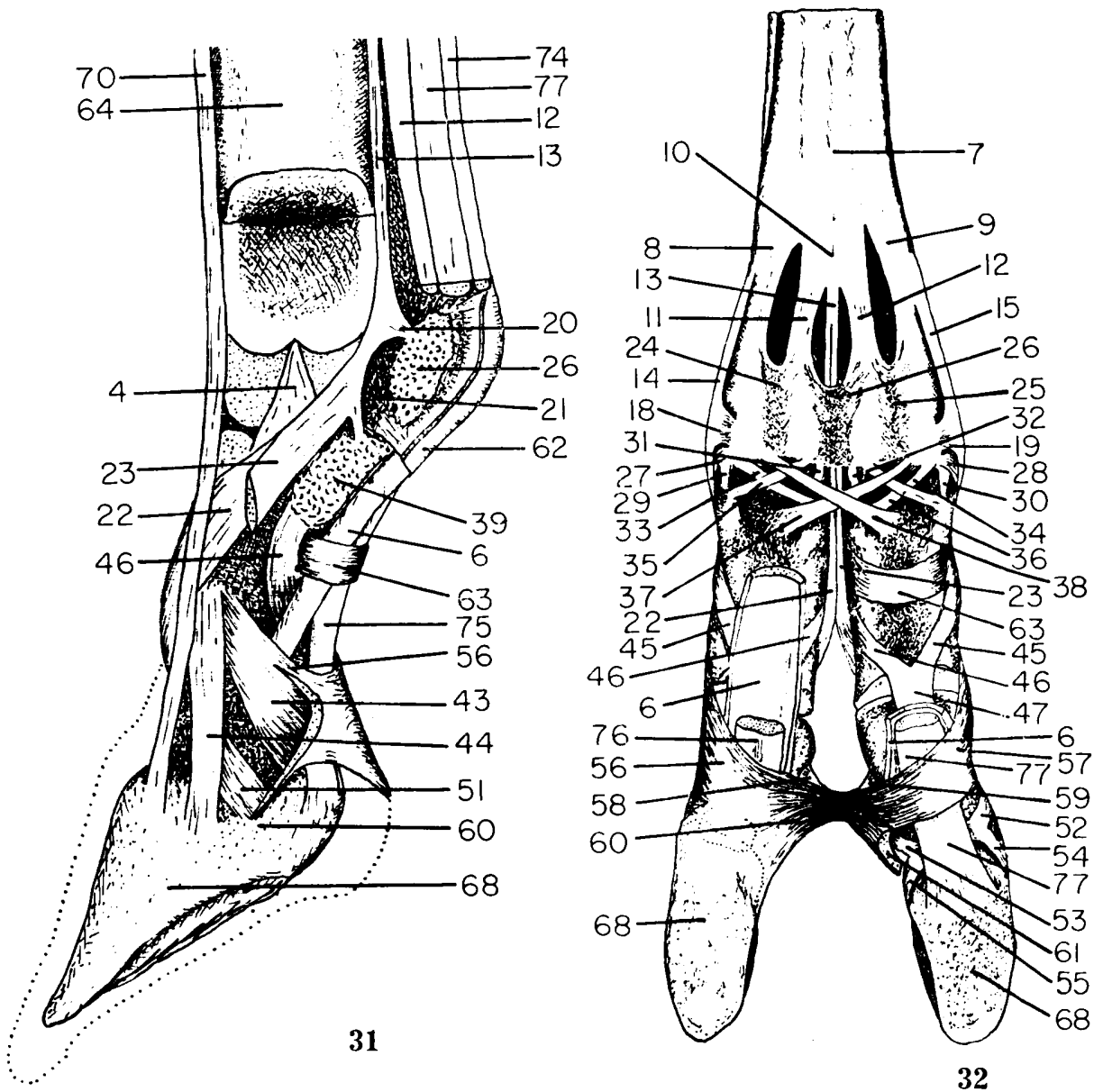

Fig. 31. Joints of digit IV in right hind-limb. Abaxial view (10-year-old male).

Fig. 32. Joints of digits in left hind-limb with joint capsules and proximal digital ligament removed (10-year-old male).

Explanations see pages 84 and 85 .

fibres decreases considerably with age. In young specimens they are particularly distinct in the distal part of the muscle.

Middle sesamoidean ligaments. The medial and lateral intersesamoidean ligaments (Fig. 32-24,25) connect the abaxial sesamoid bones to the axial ones in the corresponding digit. Impregnated with cartilaginous tissue, these ligaments constitute the bottoms of the gliding grooves for two sheaths of the deep digital flexor tendons.

The interdigital intersesamoidean ligament (Figs. 31, 32-26) connects the two axial sesamoid bones. It has, in addition, a connection with the irsterdigital branch of the middle interosseous muscle (Fig. 31-20). 
The lateral and medial collateral sesamoidean ligaments (Figs. 30, 32$-27,28)$ connect the external edges of the abaxial sesamoid bones with the tubercles for ligaments on the proximal phalanges and also by means of thin strips (not shown in the figures) with the abaxial surfaces of the two trochleae of the metatarsal bones. In some specimens synovial bursae were found under the distal attachments of these ligaments.

Distal sesamoidean ligaments. The medial and lateral abaxial oblique sesamoidean ligaments (Figs. 30, 32-29, 30) and the medial and lateral axial oblique sesamoidean ligaments (Fig. 32-31, 32) arise one from each sesamoid bone and run downward to the proximal phalanges. In European bisons they may be regarded as extensions of some fibres of the axial and abaxial portions of the middle interosseous muscle.

The lateral and medial abaxial cruciate sesamoidean ligaments (Fig. $32-33,34)$ and the lateral and medial axial cruciate sesamoidean ligaments (Fig. 32-35, 36) begin on the distal edges of the sesamoid bones corresponding to their name, below which bones they cross in pairs to end on the plantar surfaces of the proximal phalanges.

The lateral and medial phalangosesamoidean ligaments (Fig. 32-37, 38) arise from the distal edges of the axial sesamoid bones, below which they cross. The lateral ligament terminates on the proximal phalanx of digit $I I I$ and the medial one on the proximal phalanx of digit $I V$.

The proximal interdigital ligament (Fig. $31-39$ ) is a conspicuous bundle of fibres which run transversely between the surfaces of the proximal phalanges facing each other. Some fibres of this ligament reach the axial plantar ligaments of the proximal interphalangeal joints as well as the distal interdigital ligament. On the other hand, the proximal interdigital ligament receives fibres from the interdigital branch of the middle interosseous muscle (Fig. $31-21$ ).

\section{Proximal Interphalangeal Joints}

Structurally these two joints are autonomous. They are separated from each other by the fasciae and loose tissue that penetrate into the interdigital space.

The articular surface of the trochlea of the proximal phalanx has the shape of a heart whose tip is bent forward and slightly upward.

The articular fovea of the middle phalanx is an imperfect negative copy of the trochlea of the proximal phalanx.

The articular cartilage covering both articular surfaces is $1.4-1.6 \mathrm{~mm}$ thick in foetuses and newborns, $0.5-0.8 \mathrm{~mm}$ in calves up to 1 year of age, and $0.2-0.3 \mathrm{~mm}$ in adults.

The attachments of the joint capsule coincide with the margins of the articular surfaces except the dorsal surface, where the line of attachment 
is moved somewhat upwards. The joint capsule pouches upwards (dorsal pouch - Fig. 28-40), squeezing in under the tendon of the extensor muscle of digit III or $I V$. The axial pouch sinks as far as the distal interphalangeal joint on the axial side of the digit. The roomiest plantar pouch (Fig. 28-41) extends halway up the proximal phalanx. In spite of these pouches the cavity of the joint discussed is small. Its capacity is $1.5-2.0 \mathrm{ml}$ in group 0 of both sexes, $3.0-4.5 \mathrm{ml}$ in calves up to 1 year of age, $6.6 \mathrm{ml}$ in adult males and $4.6 \mathrm{ml}$ in adult females.

\section{Ligaments of the Proximal Interphalangeal Joints}

The abaxial collateral ligament (Fig. $30-42$ ) arises with the proximal portion of the distal interdigital ligament from a fossa for attachment on the proximal phalanx (Figs. 30,32-56, 57) and ends at a tubercle for attachment on the middle phalanx.

The axial collateral ligament (Fig. 31-43) much stronger than the previous one, begins in a fossa for attachment on the proximal phalanx and ends on a tubercle for attachment on the middle phalanx. In its distal section the posterior portion of fibres intertwine with the fibres of the middle portion of the distal interdigital ligament (Figs. 31, 32-58, 59). Small synovial bursae lie under the proximal and distal attachments of this ligament.

The axial collateral ligament of the proximal and distal interphalangeal joints (Fig. 31-44) extends over two joint. It begins together with the previous ligament and terminates on the axial surface of the distal phalanx. The axial pouch of the capsule of the proximal interphalageal joint is squeezed in under this ligament.

The plantar ligaments form a Y-shaped structure. Its paired parts are the axial and abaxial plantar ligaments (Figs. 30, 31, 32-45, 46) and the central plantar ligament constitutes the unpaired part (Figs. 28, 32-47). As a whole, the plantar ligaments are strong structures. Situated on the plantar side of the joint, they inhibit its hyperextension.

\section{Distal Interphalangeal Joints}

Apart from the common structure, which is the distal interdigital ligament, these joints are autonomous.

The articular surface of the trochlea of the middle phalanx is an irregular semi-cylinder. The gentle groove of the trochlea runs obliquely and consequently the trochlea resembles a screw. The angle of the curvature of the articular surface of the distal phalanx is greater than that of the curvature of the trochlea on the middle phalanx.

The articular cartilage is $1.8 \mathrm{~mm}$ thick in foetuses and newborns and ranges between 0.3 and $0.4 \mathrm{~mm}$ in adults. 
The dorsal pouch of the capsule of the distal interphalangeal joint (Fig. 28-48) extends upwards above the coronary border of the hoof for about $0.5 \mathrm{~cm}$ in the youngest specimens and up to $1.5 \mathrm{~cm}$ in adults. It reaches to the axial pouch of the proximal interphalangeal joint. The plantar pouch (Fig. 28-49), much more spacious than the dorsal one, squeezes in upwards under the insertion tendon of the,deep digital flexor and runs nearly halfway up the middle phalanx.

Between the distal phalanx and its sesamoid bone is the fissural joint cavity connected with the cavity of the distal interphalangeal joint.

\section{Ligaments of the Distal Interphalangeal Joint}

The abaxial collateral ligament (Fig. 30-50) is an isosceles triangle in shape, its apex being directed upwards. It begins on the peripheral surface of the middle phalanx, from where it tends, assuming the shape of a broad fan, towards the distal phalanx. In some European bisons the anterior margin of this ligament is accompanied by vertically running fibres which arise on the proximal phalanx. These fibres correspond to the abaxial collateral ligament of the proximal and distal interphalangeal joints.

The axial collateral ligament (Fig. $31-51$ ) is a weak fibrous structure, united with the joint capsule.

The sesamoid bone of the distal phalanx is attached to this phaianx by two small ligaments, an abaxial and an axial (Fig. 32-54, 55), and to the middle phalanx also by two, axial and abaxial, ligaments (Fig. $32-52,53)$.

The distal interdigital ligament is an unpaired symmetrical six-branched structure, having attachments on all phalanges. The lateral and medial proximal branches of this ligament (Figs. 30, 32-56, 57) take rise on the abaxial surfaces of the proximal phalanges. The stronger lateral and medial middle branches (Figs. 31, 32-58,59) arise from the surfaces of the middle phalanges facing each other, and the lateral and medial distal branches (Fig. 32-60,61) from the axial edges and surfaces of the distal phalanges and also from their sesamoid bones. The body of the distal interdigital ligament is the place where fibres of its particular branches meet and exchange.

\section{The Joints of Accessory Digits II and $\mathrm{V}$}

The bone skeleton of vestigial digits $I I$ and $V$ of European bisons consists of two rudimentary phalanges connected with each other by means of a small joint. The superior phalanx in both digits resembles a wheat grain in size and shape and the inferior one a pumpkin seed. 
The accessory digits are joined to each other and also to digits $I I I$ and IV only by loose tissue. The so-called tendons of the accessory digits are distinct structures; they arise from the connective tissue surrounding the hooves of the rudimentary digits and take the shortest way to the abaxial surfaces of the distal phalanges of the chief digits and their sesamoid bones.

\section{DISCUSSION}

The locomotive organ of the European bison, a typical inhabitant of the primaeval forest, is efficient, as regards its limbs, for all lifetime. The natural environment in which it dwells, free from human intervention, permits this animal to keep its body mass in a correct physiological relation to the biomechanical strength of its limbs and, consequently, is unpropitious to the formation of morphological distortions in them. The efficiency of the locomotive organ of the European bison is confirmed by studies on joints in the pelvic and also the thoracic limb $(\mathrm{R} \mathrm{a} \mathrm{do} \mathrm{m-}$ $\mathrm{sk} \mathrm{i,} \mathrm{1972).} \mathrm{Neither} \mathrm{have} \mathrm{pathological} \mathrm{changes} \mathrm{been} \mathrm{found} \mathrm{in} \mathrm{the} \mathrm{osseous}$ anc muscular systems (E mpel \& Roskosz, 1963; Świeżyński, 1962). The cases of deformation in the limb joint of European bisons signalled in literature ( $\mathrm{J}$ uś k o, 1953; R a d o m ski \& Kobr yń, 1969) and changes in the articular cartilages of the stifle joint observed in the present study constitute a very small proportion of the large number of specimens examined.

It is thought that in its manner of locomotion the European bison is similar rather to small ruminants like sheep, goat, roe, etc. than to the domestic cattle ( $\mathrm{Szt}$ ol c m a n, 1926; W r ó blew s ki, 1927). Its muscular system also shows more similarities to this system of, e.g., the deer o: sheep than to that of the cow ( $\mathrm{S} w$ i e ży ński, 1962). On the other hand, in skeleton morphology it comes nearer to domestic cattle than to small ruminants (E. m p e 1, 1962; R os k os z, 1962; E m p e l \& R os k os z, 1963; K o b r y ń, 1973).

In studies carried out so far (Empel \& Roskosz, 1963) the age at which the pelvic symphysis undergoes ossification is given in approximation. The author's own observations have permitted the specification of the time and duration of ossification of this joint, allowing for dimorphic differences.

The newborns and calves of European bisons, like other mammals ( $\mathrm{K} \mathrm{o}$ s ty ra, 1962; B ochenek \& R e icher, 1968), have their acetabula shallow and, compared with domestic cattle (Vokken et al., 1961), kisons have the acetabular lip lower.

The lack of the ligament of the femoral head is observed in many mammals (Bochenek \& R e icher, 1968; K ostyra, 1962). Among 
others it has not been met within one of the European bison domestic cattle hybrids examined (own observation). The reduction of this structure is accompanied also by the disappearance of the fovea in the femoral head. The great individual variation of the ligament of the femoral head in European bisons with regard to its size and thickness and the complete disappearance of this ligament in some mammals indicate that unlike all the other ligaments of the joint it does not strengthens the frame of the joint (Vokken et al., 1961), but in all probability serves as a track for the passage of the blood-vessels supplying the femoral head. The mediocre mechanical role of this ligament is suggested by the fact that it is not built of fibroconnective tissue but of fibrocartilaginous one (A k a jevskij, 1968). The macroscopic appearance of the ligament of the femoral head in European bisons confirms its cartilaginous structure, except for its extraacetabular part built of fibroconnective tissue.

Table 16

Articular angles of European bison at the time of walking (in degrees).

\begin{tabular}{lccc}
\hline Angle & In flexion & In extension & Range of movement \\
\hline Vertebral column - hip & 158 & 158 & 0 \\
Hip - femur & $\mathbf{5 5}$ & 112 & $\mathbf{5 7}$ \\
Femur - tibia & 121 & 128 & 7 \\
Tibia - metatarsus & 136 & 156 & 20 \\
\hline
\end{tabular}

1 After W ęgrzyn \& Ser watk a (1961)

In contradistinction to domestic cattle but similarly to the horse ( $\mathrm{K}$ ad l e t z, 1932) the European bison possesses the ilioischiofemoral ligament in the hip joint. On the other hand, it lacks the pubofemoral ligament observed in domestic cattle ( $\mathrm{V} \mathrm{ok} \mathrm{k} \mathrm{e} \mathrm{n}$ et al., l.c.), in which it strengthens the capsule of the hip joint on the ventral side. These differences in the structure of the fibrous membrane which makes up both the ligaments mentioned persuade us to suppose that unlike the cow but very like the horse the European bison can perform rapid movements straightening the hind legs to the rear, colloquially called "kicking ", as reported by Wróblewski (1927).

In European bisons the rotation axes of the two hip joints lie in a horizontal plane and cross at $120^{\circ}$ in the pelvic cavity. As a result, at the time of flexion in these joints the stifles alternately straddle the belly and the femora describe the curved surface of conic sectors. The deviation of the stifles to the outside in their straddling the belly has been established at $35^{\circ}$ in the cow (V o k ke n et al., 1961) and it is undoubtedly smaller in European bisons on account of the fact that their abdominal tunics are pulled up. The weight ratio of the organs of the alimentary 
system to the body is greater in domestic cattle and European bison-domestic cattle hybrids than in European bisons (S z u l c et al., 1971; P y t e l, 1969). Further, the abdominal tunic is better developed in European bisons than in domestic cattle ( $\mathbf{S} w i$ e ży n s ki, 1962). As a result of all this, the belly of the European bison does not flag so loosely and, what follows, the femora move in planes approximating to sagittal ones during flexion at the hip joint. Hence, the European bison has a »light and graceful « step (W r ó blewski, 1927), in which, perhaps just for this reason, it resembles small ruminants $(\mathrm{S} z \mathrm{t}$ o $\mathrm{l} \mathrm{cm}$ a $\mathrm{n}, 1926)$.

In Bison bison (own observations) the capacity of the hip joint cavity is $38 \mathrm{ml}$ and in cows $50 \mathrm{ml}$ ( $\mathrm{V} \mathrm{okke} \mathrm{n}$ et al., l.c.). In adult European bisons this capacity has intermediate values.

In domestic cattle the lateral meniscus is longer and broader than the medial one (A bieljanc, 1957) and thus, except for a few cases, the situation here is opposite to that in European bisons. However, the lateral meniscus is thicker than the medial in all, European bisons, domestic cattle, and European bison-domestic cattle hybrids (M o n t a n é \& B o u rdelle, 1917).

The menisci of European bison-domestie cattle hybrids compared with those of European bisons (Table 7) are characterized by morphological heterosis, and so are the internal organs of these hybrids (Pyte 1 \& Krasińska, 1971; Szulc et al., 1971).

The symmetry of the stifle joint depends on the size ratio of the menisci (A bieljanc, 1959). The more menisci resemble each other in shape and size, the more symmetrical the stifle is and, consequently, the more efficacious it is as an element of the locomotive organ. Digitigrades have symmetrical stifle joints, plantigrades asymmmetrical ones, and ungulates hold an intermediate position. In this respect the stifle joint of European bisons must be regarded as more symmetrical than that of European bison-domestic cattle hybrids.

It is thought (A biel janc, 1957; Aka jevskij, 1968; Brühl, 1969) that as fibrocartilaginous structures the menisci absorb shocks in the stifle joint. In the author's opinion, their presence in the gap of the femorotibial joint conditions also the simultaneous occurrence of two sorts of movements, gliding and rolling.

The transerverse ligament of the stifle, present in other mammals (A bieljanc, 1957; Kostyra, 1962, Vokken et al., 1961; Bochenek \& Reicher, 1968), is missing in European bisons. The lack of this structure has also been observed in $F_{1}$ European bison-domestic cattle hybrids and in Bison bison. On the other hand, in all European bisons a small ligamental structure, absent from other mammals, has been found extending from front to rear between the intercondylar tu- 
bercles of the tibia; the term "longitudinal ligament of stifle (lig. longitudinale genus) " has been proposed for it (Fig. 11-24).

The insertions of the collateral ligaments of the femorotibial joint, situated relatively low on the tibia, allow the condyles of the femur to glide over the articular surface of the tibial condyles, forward during extension and backward during flexion. As in other ungulates (V ok k e $\mathrm{n}$ et al., 1961), these ligaments are tensed very much when the stifle joint is extended, preventing any movements except those sagittal in direction. A small range of adduction, abduction and rotation is possible when the joint is half-flexed or flexed and the collateral ligaments are moderately slackened. The tension and relaxation of these ligaments is caused by the fact that the fossae for their attachment on the femur do not lie in the rotation axis of the femorotibial joint, but above it and somewhat to the rear. Writers differ in opinion as to the structure of the lateral collateral ligament of the femorotibial joint. This ligament is believed to arise from the fibres of the fibrous membrane of the joint capsule and those of the tendon of the peroneus longus muscle ( $\mathbf{S} w i$ e ży n $\mathrm{ski}$, 1962), or exclusively from the fibres of the capsule ( $\mathrm{P}$ e l e in e r, 1932). The author's investigation confirms the first view and at the same time it shows that some of the fibres of the lateral collateral ligament extend downward to form the superficial layer of the fibrous band of the leg.

The cruciate ligaments of the stifle joint (E 11 e n berge r \& B a u m, 1943; P oplew ski, 1934) are said to inhibit hyperextension in this joint. Observations made on preparations of the stifle joints of European bisons show that these ligaments, in addition, fulfil the task, not less important, of gliding the femoral condyles over the articular surfaces of the tibial condyles. This function is performed as follows: while the stifle joint is being straightened, the anterior cruciate ligament winds on the semi-cylinder formed by the bottom of the intercondylar fossa of the femur. As a result, the ligament is shortened and pulls the distal end of the femur to the front. In flexion the anterior cruciate ligament unwinds and, in turn, the posterior cruciate ligament becomes wound on the semi-cylinder mentioned; thus shortened, it pulls the distal end of the femur backwards. The menisci which constitute the natural substratum of the condyles of the femur, travel forward and backward together with them.

There are controversial views on the communication betweeen the two cavities of the femorotibial joint in domestic cattle. Some investigators think that these cavities are isolated from each other ( $\mathrm{C}$ h a u v a $\mathrm{u}$ et al., 1903; Sisson \& Grossman, 1960) and others claim that there is always a communication between them (Vok ke n et al., 1961; $\mathrm{Nic-}$ kel et al., 1960). My own observations show that hardly 7 European 
bisons in a hundred, and then chiefly old ones, have the two cavities connected, whereas in most European bisons, European bison-domestic cattle hybrids, Watussi cattle and buffaloes they are isolated from each other by a joint partition. Admittedly, however, there is a communication between the medial sac of the femorotibial joint and the cavity of the $f \in$ moropatellar joint in all the Bovinae not excluding European bisons.

According to some authors (Ell e n berger \& B a u m, 1943; Vok$\mathrm{k}$ e $\mathrm{n}$ et al., l.c.), all the patellar ligaments are the insertion tendons of the quadriceps muscle of the thigh. A b i el j a n c (1962) writes that only the middle patellar ligament is derived from that muscle, whereas the medial patellar ligament has origin from the medial femoropatellar ligament. In his and other author's opinion (S i s s on \& G r o s s m a n, 1960), in respect of derivation the lateral patellar ligament is associated with the lateral femoropatellar ligament and the tendon of the biceps muscle of the thigh.

In European bisons the middle patellar ligament is the downward extension of the fibres of the rectus muscle of the thigh and, partly, the lateral vastus muscle. The author is of opinion that the medial patellar ligament of these animals is as a whole a product of the fibrous membrane of the joint capsule, from which also the lateral patellar ligament arises (medial portion), receiving some fibres from the tendon of the biceps muscle of the thigh (lateral portion).

European bisons and $F_{1}$ European bison-domestic cattle hybrids have a ligamental structure which does not occur in domestic cattle but is observed in a somewhat modified form in the pig ( $\mathrm{K}$ os ty ra, 1962), i.e. the femoropatellotibial ligament (Figs. 12, 14-34). This ligament arises from the combination of the medial femoropatellar ligament proper with the aponeurosis of the fedial vastus muscle and the fascia genus.

The lateral femoropatellar ligament is not present in European bisons.

The opinion prevails (A b i e l j a n c, 1955, 1962) that in domestic cattle, as in the horse but to a smaller extent, the so-called static loop exists in the stifle joint, locking it whenever the animal rests in a standing position. The elements of this loop are, among others, the middle and medial patellar ligaments and the medial ridge of the femoral trochlea. In European bisons and $F_{1}$ European bison-domestic cattle hybrids the loop should be still more efficacious than it is in domestic cattle on account of its additional element, which is the femoropatellotibial ligament.

In the shanks of some European bisons and one buffalo examined the rudimentary fibulas were found (Fig. 18), which had not even been mentioned before in the osteology of limbs of the European bison ( $\mathrm{Empel}$ \& R o s k o s z, 1963) and domestic cattle. 
A peculiarity of the hock joint is that in comparison with other synovial joints its postnatal development is small, as evidenced by the small increments in its chief cavity and the small growth of its osseous components after birth (K o b r y n c z u k \& K o b r y ń, 1973).

The relative thinness of the articular cartilage of the tarsocrural joint in European bisons is worthy of notice, and this is true as regards juvenile specimens. It is generally accepted that articular cartilage thickens during work (Vokken et al., 1961) and that its thickness is proportional to the pressure exerted on it (B o chen e k \& R e i cher, 1968). However, P o p l e w s ki (1927) gives a different opinion. According to him, pressu$r \in$ makes articular cartilage thinner. This last view would seem to be true, since, for instance, the stress in the tarsocrural joint of European bisons is greater than that in the femoropatellar joint and yet its articular cartilage is considerably thinner than that in the latter joint.

Synovial fossae (Fig. 19) in the hock joint are noticeable. The distribution of these structures and the role they play in mammals have not as yet been explained. A bi el ja n c (1968) finds them situated most frequently in the elbow, hip, hock and metacarpo- and metatarsophalangeal joints. In man synovial fossae are believed to be pathological lesions ( $\mathrm{r}$ ü hl, 1969). Some writers (Vokk en et al., l.c.) think that their function is to produce synovial fluid. The accumulation of synovial fossae in the tarsal joint of European bisons suggests another hypothesis, namely, that they appear in joints in which a relatively large articular surface is accompanied by a synovial membrane small in area, which is the case in the tarsal joint.

In European bison;, as in other Paraxonia, two funcionally equivalent joints occur in the hock, the tarsocrural and the proximal intertarsal. The flexion-extension range approximates to $65^{\circ}$ in the first of these joints and to $95^{\circ}$ in the second, adding to $160^{\circ}$. This cumulative flexion-extension range is great relative to the "demands " of the tarsal joint during normal walk. It should then be supposed that the tarsocrural and proximal intertarsal joints do not work simultaneously, the first of them being active during normal walk, whereas the other joint is activated only in situations demanding special effort, e.g., in fighting with the horns or climbing up a hill. In both cases, however, the straightening force $F$ (Fig. 27) is equal, the tuberosity of the tibial tarsal bone being the point of its application. There are two arms of this force, $p$ and $q$. The shorter arm $p$ arises from the rotation centre of the tarsocrural joint (0), the other, longer arm $q$ begins at the rotation centre of the proximal intertarsal joint. Thus, we are here concerned with two moments of one and the same force, for which

$$
F \cdot p<F \cdot q
$$


The dorsal pouches of the capsules of both metatarsophalangeal joints have greater absolute dimensions in European bisons than in cattle ( $\mathrm{E} \mathrm{m-}$ pel, 1969); they are $6 \mathrm{~cm}$ long in cows and may reach up to $8 \mathrm{~cm}$ in European bisons.

In cows two axial collateral ligaments of the metatarsophalangeal joints have been reported ( $\mathrm{Köhler,} \mathrm{1902;} \mathrm{Nickel} \& \mathrm{Langer,1953)} \mathrm{to}$ have their anterior edges joined. In European bisons these ligaments are anteriorly connected only by the synovial membrane. Moreover, the abaxial collateral ligaments of the metatarsophalangeal joints are uniform structures in cows, evidently consisting of two layers in European bisons (Fig. $30-3$ ).

Macroscopic observation of the middle interosseous muscle of the European bison made it possible to compliment the results obtained by $\mathrm{S} w$ i e$\dot{z} \mathrm{y} n$ s k i (1962). Muscle fibres embedded in the fibrous structure of this muscle belong only to its deep portion, naturally before its division into branches. Red muscle fibres were observed on non-fixed preparations of this muscle, both on its surface and in sections. In longitudinal sections these fibres concur in four vertical trips separated from each other by strips of fibrous tissue, whereas in cross-sections there appear four fields lying side by side and consisting of concentric rings or arches of muscular tissue. In both cases the arrangement of the muscle fibres is reminiscent of the four interosseous muscles in the tetradactyl limb. In contradistinction to the situation found in the horse, in which the proximal portion of the middle interosseous muscle contains more muscle fibres (K r y siak, 1937/38), in European bisons more of these fibres are accumulated in the distal portion of the muscle discussed.

The presence of muscular tissue in the interosseous muscle is observed in all European bisons, this tissue being particularly abundant in juveniles, whereas in domestic cattle (Vokken et alt., 1961) its fibres are met with only in calves. N i ckel et al. (1960) hold the opinion that in small ruminants this element has a muscular structure, but $R$ eise $r$ (1903) wrote nothing on this subject in his study on the muscular system in small ruminants. If however $\mathrm{Nickel}$ et al. (1960) are right, the middle interosseous muscle of European bisons would be more similar in this respect to this muscle in small ruminants than to its counterpart in domestic cattle.

In the deer, sheep and goat ( $\mathrm{R}$ e is e $\mathrm{r}, 1903$ ) the interdigital branch of the middle interosseous muscle, before sinking under the interdigital intersesamoidal muscle, sends off fibres symmetrically to the sides, to the axial sesamoid bones, which has also been found in European bisons but in a small number of specimens.

The plantar pouch of the proximal interphalangeal joint extends one- 
third of the way up the proximal phalanx in domestic cattle (E m pel, 1969 ) and therefore it is shorter here than in European bisons. N i c k e l \& L a n g e r (1953) have found this pouch situated farther to the outer side in cattle than it is in European bisons.

No elastic ligaments have been encountered in the distal interphalangeal joint of the European bison, whereas in domestic cattle it is situated on the antero-axial side of the joint ( $\mathrm{Köhle} \mathrm{r}, 1902)$, neither has the elastic nature of the ligament of the sesamoid bone of the distal phalanx been established, although it has been recorded from domestic cattle by $\mathrm{Nickel} \& \mathrm{~L}$ ang e r (1953).

Swieży ski (1962) writes that the middle interosseous muscle in the fore-limb of the European bison gives off special branches to accessory digits $I I$ and $V . \mathrm{R}$ a d o m s k (1972) is of the opinion that these digits in the fore-limb of the European bison have no direct connection with the middle interosseous muscle, but are held, above all, by the fascia metacarpi. The same opinion is expressed by $\mathrm{K}$ ö h l e r (1902) with regard to the attachment of these digits in domestic cattle and a similar situation has also been observed in the hind-limbs of European bisons.

Information concerning the osseous structure of rudimentary digits II and $V$ of domestic cattle is controversial ( $\mathrm{N} \mathrm{ickel}$ et al., 1960; Vokken et al., 1961). In bisons, European bisons and Watussi cattle each rudimentary digit consists of two phalanges. It would be inconsiderate to claim that in the Bovinae it is the distal phalanx that is absent from such digits, although this would be suggested by the law of reduction of digits ( $\mathrm{P}$ o p l e w s ki, 1948).

The tendons of accessory digits $I I$ and $V$ should be considered, in spite of their name, to be descended from the interdigital ligaments, connecting the abaxial digits with the axial ones in tetractyl animals. The mechanical role of the accessory digits of the European bison seems to be clear. Their hoofs bear sings of wear and therefore, notwithstanding their high position, they come into contact with a soft substratum, thus increasing the bearing surface of the digital organ in these animals. Easy movements of European bisons on swampy and miry ground is mentioned also by W r ó blewski (1927).

It is difficult to determine the angles formed by long bones meeting in joints on carcasses and the flexion-extension range of movements in particular joints of moving European bisons. The method of determination of these values on the basis of photographs is not precise and this is why values obtained in this way, offered in Table 16, are left without any comments.

At an analysis of the dimensions of structures making up particular joint of bones in the hind-limbs of European bisons it should be stated 
in general that the postnatal growth of these joints in males of groups 0 , I and II is intenser than in females of the same age groups. In adult European bisons become smaller and smaller in males of groups III-V, this drop in increase being milder in females.

Moreover, it may be stated that the dimensions presented are nearly always larger in males and so are the growth coefficients.

\section{REFERENCES}

1. Abieljanc G. S., 1955: Anatomo-funkcjonalnye osobennosti bedro-kolennnogo sustava lošadi $\mathrm{v}$ svjazi so statikoj i dinamikoj tazovoj konečnosti. Tr. Kijev. Viet. Inst., 12: 114-124. Kijev.

2. A bieljanc G. S., 1957: Meniskovo-svjazočnyj apparat kolena svini, lošadi, krupnogó skota $\mathrm{i}$ jego rol' $\mathrm{v}$ funkcyji sustava. Tr. Kijev. Viet. Inst., 13: 271-277. Kijev.

3. Abieljanc G. S., 1959: Typy kolinnoro suhloba ssavciv. Nauk. Praci Vet Fak., 14: 153-154. Kyjiv.

4. Abieljanc G. S., 1962: Prjami zvjazky kolinnoji časky svyni, velykoji rohatoji hudoby $\mathrm{i}$ koni ta ih rol $\mathrm{u}$ funkcii kolinnoho suhloba. Nauk. Praci Vet. Fak., 25, 18: 68-74. Kyjiv.

5. Abieljanc G. S., 1968: Kistkovo-zvjazkovyj pojas kolinnoho suhloba palcehidnyh ssavciv. Zahody Min. Silsk. Gosp. URSR, 3: 171-173. Kyjiv.

6. A kajevskij A. I., 1968: Anatomia domašnih životnyh. Izd. Kolos: 1-230. Moskva.

7. B ochenek A. \& R eicher M., 1968: Anatomia człowieka. Państw. Zakł. Wyd. Lek., Warszawa.

8. Brühl W. (ed.), 1969: Choroby narządu ruchu. Państw. Zakł. Wyd. Lek., Warszawa.

9. Chaveau A. \& Arloing S., 1903: Traité d'anatomie comparée des animaux domestiques. Bailliére, 1: 1-684. Paris.

10. Davletova L. V., 1960: The growth of digestion organs in the course of ontogenesis in sheep. Biul. Mosk. Obšč. Isp. Prirody, Biol., 65, 2: 107-119. [In Russian with English summ.].

11. Duerst J. U., 1926: Vergleichende Untersuchungsmethoden am Skelett bei Säugern. Urban und Schwarzenberg, 7: 125-530. Berlin-Wien.

12. Ellenberger W. \& Baum H., 1943: Handbuch der vergleichenden Anatomie der Haustiere. Springer, 1: 1-1155. Berlin.

13. Empe1 W., 1962: Morphologie des Schädels von Bison bonasus (Linnaeus, 1758). Acta theriol., 6, 4: 53-111.

14. Empel W., 1969: Studia nad anatomią chirurgiczną i rentgenowską palców bydła. Zeszyty Nauk. SGGW, 1: 7-50.

i5. Empel W. \& Roskosz T., 1963: Das Skelett der Gliedmassen des Wisents, Bison bonasus ( $\mathrm{L}$ i n $\mathrm{n}$ a e u s, 1758). Acta theriol., 7, 13: 259-300.

16. J a n icki S., 1938: Badania nad szkieletem żubra (Eison bonasus L.). Prace Roln.-Leśne P.A.U., 27: 1-55.

17. J u śko J., 1953: Dimorfizm płciowy szkieletu żubra (Bison bonasus). Folia morphol., 4, 1: $1-30$.

18. Ka dletz M., 1932: Anatomischer Atlas Extremitätengelenke von Pferd und Hund. Urban und Schwarzenberg: 1-71. Berlin-Wien. 
19. Kobryn H., 1973: The thorax in European bison and other ruminants. Acta theriol., 18, 17: 313-341.

20. Kobryń H. \& Kobryńczuk F., 1973: Pseudoarthrosis in the European bison. Acta theriol., 18, 18: 347-350.

21. Kobryńczuk F. \& Kobryń H., 1973: Postembryonic growth of bones of the autopodia in the European bison. Acta theriol., 18, 16: 289-311.

22. $\mathrm{K} \circ \mathrm{ch}$ W., 1932: Über Wachstums- und Altersveränderungen am Skelett des Wisents. Abh. Mat.-naturw. Abt., Bayer. Akad. Wiss., Supl.-Bd., 15 Abh.: 555-678 .

23. Kosty r a J., 1960: Połączenia kości w kończynach świni domowej. Annls Univ. M. Curie-Skłodowska, Ser. DD 15, 11: 137-190.

24. Köhler A. A., 1902: Untersuchungen über Phalangenbänder der Hausthiere und da Vorkommen der Sesambein an Zehen der Fleischfresser. Arch. wiss. prakt. Thierheilkunde, 29: 69-108. Berlin.

25. Krysiak K., 1937/38: W sprawie uścięgnienia mięśnia międzykostnego pośrodkowego u Equidae. Folia morphol., 8.

26. Krysiak K., 1951: Więzadło karkowe (Ligamentum nuchae) żubra - Bison bonasus. Folia morphol., 2, 10: 271-283.

27. Martin P. \& Schauder W., 1938: Lehrbuch der Anatomie der Haustiere - 3: 1-560. Schickhardt. Ebner, Stuttgart.

28. Montané L. \& Bourdelle E., 1917: Anatomie regionale des animaux domestiques (Ruminants):, 2: 1-368. Paris.

29. Nickel R. \& L a nge r P., 1953: Zehengelenke des Rindes. Tierärztl. Wschr., 14: 211-253. Berlin und München.

30. Nickel R., Schummer A. \& Seiferle E., 1960: Lehrbuch der Anatomie der Haustiere. Parey, 1: 1-206. Berlin-Hamburg.

31. Nomina Anatomica Veterinaria, 1973: Vienna.

32. Pilarski W. \& Roskosz T., 1957: Zjawisko ukrzyżowienia (sacralisatio) ostatniego kręgu ledźwiowego u samic żubra - Bison bonasus (L.). Folia morfol., 2: 109-119.

33. Pilarski W., Serwatka S., Swiézyński K. \& Węgrzyn M., 1967: New attempts af fixing anatomical material of large mammals. Acta theriol., 12, 31: 353-358.

24. Poleiner R., 1932: Der anatomische Aufbau der Extremitäten beim Europäischen Wisent (Bison bonasus L.) im Vergleich zum Hausrind. Diss. Wien.

35. Poplewski R., 1927: Celowość budowy i rozmieszczenie stawów. Wych. Fiz. Warszawa.

36. Poplewski R., 1934: Rozważania teoretyczne nad budową długich kości saków. Spr. z Pos. Tow. Nauk. Warsz., 26 (1933): 1-14.

37. P oplewski R., 1948: Anatomia ssaków. 2: 1-690. Spółdz. Wyd. Czytelnik, Stockholm.

38. Pytel S. M., 1969: Morphology of digestive tract of the European bison. Acta theriol., 14, 27: 349-402.

29. Pytel S. \& Krasińska M., 1971: Morphology of the stomach and intestines in hybrids of European bison and domestic cattle. Acta theriol., 16, 31: 471-481 .

40. R a domski R., 1972: Stawy kończyn piersiowych żubra, Bison bonasus (L.), w rozwoju postnatalrym. Diss. SGGW, Warszawa.

41. Radomski R. \& Kobryń H., 1969: Powikłane skręcenie (distorsio) stawu barkowego żubra (Bison bonasus L.). Med. wet., 25, 3: 144-145. 
42. Reiser E., 1903: Vergleichende Untersuchungen über die Skelettmuskulatur von Hirsch, Reh, Schaf und Ziege: 1-42. Diss. Bern-Wien.

43. Roskosz T., 1962: Morphologie der Wirbelsäule des Wisents, Bison bonasus (L i n n a e u s, 1758). Acta theriol., 6, 5: 113-164.

44. Sis on S. \& Grossman J., 1960: The anatomy of the domestic animals.: 20-203. Saunders, Philadelphia-London.

45. Sokolov I. I., 1972: Postkranjalnyj skelet predstavitelej roda Bison. Tr. Zool. Inst., AN SSSR, 48: 198-219.

46. Sztolcman J., 1926: Żubr, jego przeszłość i przyszłość: 1-104. Nakł. Centr. Zw. Pol. Stow. Łow., Warszawa.

47. Szulc M., Tropiło J. \& Krasińska M., 1971: Dressing percentage and utility value of the meat of European bison and domestic cattle hybrids. Acta theriol., 16, 32: 484-504.

48. Swieży nki K., 1962: The skeletal musculatural system of the European bison, Bison bonasus (L i n n a e u s, 1758). Acta theriol., 6, 6: 165-218.

49. Węgrzy M. \& S e rwatka S., 1961: Ligamentum sacrotuberale latum bei Bison bonasus (Linnaeus, 1758) und Bos taurus (Linnaeus, 1758). Acta theriol., 5, 7: 73-97.

50. Vokken G., Glagoliev P. \& Bogoljubskij C., 1961: Anatomia domašnih životnyh. 1: 39-236. Gos. Izdat. Vyssaja Škola, Moskva.

51. Wróblewski K., 1927: Żubr Puszczy Białowieskiej. 1-232. Wyd. Polskie, Poznań.

52. Ż a biński J. (Ed.), 1947-65: Pedigree book of the European bison. 1-370. Państw. Wyd. Nauk., Warszawa.

53. Ż a biński J. \& R a c zyńs ki J. (Eds.), 1972: European bison pedigree book 1965-69. 1-78. Państw. Wyd. Nauk., Warszawa.

Accepted, January 20, 1975.

\section{Franciszek KOBRYÑCZUK}

POEĄCZENIA KOSCI KOŃCZYN MIEDNICZNYCH ŻUBRA W ROZWOJU POZAPEODOWYM

\section{Streszczenie}

Badania przeprowadzono na zwłokach 71 żubrów (47 samców i 24 samic). Ponadto dokonano obserwacji powierzchni stawowych na kośćcach 48 żubrów (27 samców i 21 samic) stanowiących część zbiorów muzealnych Ośrodka Badań nad Anatomią Żubra przy Akademii Rolniczej w Warszawie. Padłe zwierzęta pochodziły z krajowych ośrodków hodowlanych. Materiał podzielono na 6 grup obejmujących zwierzęta począwszy od płodów tuż przed urodzeniem i noworodków aż do osobników najstarszych. W celach porównawczych przeprowadzono również fragmentaryczne badania na innych Bovinae a między innymi na bydle domowym i krzyźówkach bydła domowego $\mathrm{z}$ żubrem.

Zbadano wszystkie połączenia kości w kończynach miedniczych. $\mathrm{W}$ badaniach tych określono, posługując się metodą własną, wielkość kątową krzywizn powierzchni stawowych, wartość promieni i cięciw tych krzywizn oraz inne parametry kątowe. $\mathrm{Na}$ zwłokach świeżych zbadano pojemność i kształt jam stawowych przez wprowadzenie doń kolorowego, ciepłego roztworu żelatyny. Ponadto na zwlokach utrwalonych przy pomocy formaliny zmierzono grubość chrząstek stawowych oraz dokonano pomiarów więzadeł i łąkotek. Poza tekstem ujmującym morfologię połączeń, badania udokumentowano 16 tabelami i 32 rysunkami wykonanymi przez autora. 
Table 10

Dimensions of ridges of femoral trochlea (in $\mathrm{mm}$ and degrees).

\begin{tabular}{|c|c|c|c|c|c|c|c|c|c|c|c|c|c|c|c|}
\hline \multirow{3}{*}{ Species, sex } & \multirow{3}{*}{$\begin{array}{l}\text { Group, } \\
\text { name }\end{array}$} & \multirow{3}{*}{ No. } & \multicolumn{6}{|c|}{ Lateral ridge } & \multirow{2}{*}{\multicolumn{3}{|c|}{ Length }} & \multicolumn{4}{|c|}{ ridge } \\
\hline & & & \multicolumn{2}{|c|}{$\begin{array}{l}\text { Length } \\
\text { (chord) }\end{array}$} & \multicolumn{4}{|c|}{ Curvature } & & & & \multicolumn{4}{|c|}{ Curvature } \\
\hline & & & $\overline{\mathbf{x}}$ & & $\overline{\mathrm{x}}^{r}$ & $\overline{\mathbf{x}}$ & $\begin{array}{c}\text { Angl } \\
\mathrm{s} \\
\end{array}$ & $\mathrm{le}$ & \multicolumn{2}{|c|}{$\begin{array}{l}\text { Length } \\
\text { (chord) }\end{array}$} & $\mathrm{v}$ & $\bar{r}$ & $\bar{x}$ & $\underset{\mathrm{s}}{\text { Angle }}$ & $\mathrm{v}$ \\
\hline European bison, $M$ & $\begin{array}{r}0 \\
\text { I } \\
\text { II } \\
\text { III } \\
\text { IV } \\
\mathrm{V} \\
\text { G.C. }\end{array}$ & $\begin{array}{r}8 \\
5 \\
16 \\
17 \\
15 \\
13\end{array}$ & $\begin{array}{cc}52.0 & 3 \\
61.1 & 2 \\
80.6 & 4 \\
85.3 & 7 \\
89.4 & 3 \\
87.9 & 7 \\
1.69\end{array}$ & $\begin{array}{ll}3.9 & 7.5 \\
2.2 & 3.6 \\
4.4 & 5.4 \\
7.9 & 9.3 \\
3.6 & 4.0 \\
7.9 & 9.0\end{array}$ & $\begin{array}{l}31.5 \\
35.9 \\
41.9 \\
43.5 \\
45.5 \\
44.8 \\
1.42\end{array}$ & $\begin{array}{c}111 \\
117 \\
148 \\
157 \\
159 \\
158 \\
1.42\end{array}$ & $\begin{array}{l}1.0 \\
3.5 \\
9.7 \\
3.9 \\
4.4 \\
6.2\end{array}$ & $\begin{array}{l}0.9 \\
3.0 \\
6.6 \\
2.4 \\
2.8 \\
3.9\end{array}$ & $\begin{array}{r}57.0 \\
77.5 \\
107.3 \\
113.1 \\
115.9 \\
114.1 \\
2.00\end{array}$ & $\begin{array}{l}9.0 \\
1.4 \\
7.8 \\
5.6 \\
4.5 \\
6.0\end{array}$ & $\begin{array}{l}5.3 \\
1.8 \\
7.3 \\
5.0 \\
3.9 \\
5.2\end{array}$ & $\begin{array}{l}35.2 \\
47.2 \\
62.3 \\
64.2 \\
64.3 \\
62.3 \\
1.78\end{array}$ & $\begin{array}{l}108 \\
110 \\
119 \\
123 \\
128 \\
129 \\
1.19\end{array}$ & $\begin{array}{r}4.6 \\
11.7 \\
11.3 \\
9.4 \\
3.3 \\
41\end{array}$ & $\begin{array}{l}4.2 \\
1.5 \\
95 \\
7.6 \\
2.6 \\
3.2\end{array}$ \\
\hline European bison, F & $\begin{array}{r}0 \\
\text { I } \\
\text { II } \\
\text { III } \\
\text { IV } \\
\mathrm{V} \\
\text { G C. }\end{array}$ & $\begin{array}{r}4 \\
1 \\
9 \\
6 \\
7 \\
18\end{array}$ & $\begin{array}{l}48.3 \\
65.0 \\
71.3 \\
75.8 \\
78.8 \\
81.8 \\
1.69 \\
1.69\end{array}$ & $\begin{array}{ll} & \\
1.8 & 2.5 \\
3.7 & 4.9 \\
5.0 & 6.3 \\
3.3 & 4.0\end{array}$ & $\begin{array}{l}29.2 \\
37.0 \\
37.7 \\
39.2 \\
40.3 \\
42.5 \\
1.46\end{array}$ & $\begin{array}{c}111 \\
123 \\
142 \\
150 \\
156 \\
154 \\
1.39\end{array}$ & $\begin{array}{l}8.2 \\
2.0 \\
6.0 \\
5.6\end{array}$ & $\begin{array}{l}5.8 \\
1.3 \\
3.8 \\
3.6\end{array}$ & $\begin{array}{r}57.7 \\
81.0 \\
94.7 \\
100.5 \\
103.6 \\
106.7 \\
1.85\end{array}$ & $\begin{array}{l}9.3 \\
4.5 \\
6.6 \\
5.3\end{array}$ & $\begin{array}{l}9.8 \\
4.5 \\
6.4 \\
5.0\end{array}$ & $\begin{array}{l}34.5 \\
46.0 \\
56.4 \\
56.9 \\
58.7 \\
60.1 \\
1.74\end{array}$ & $\begin{array}{c}113 \\
122 \\
114 \\
124 \\
124 \\
123 \\
109\end{array}$ & $\begin{array}{r}9.3 \\
4.7 \\
10.4 \\
8.5\end{array}$ & $\begin{array}{l}8.2 \\
38 \\
8.4 \\
6.3\end{array}$ \\
\hline $\begin{array}{l}\text { Bison bison, } F \\
\text { Bison bison } \\
\text { - B bonasus }\end{array}$ & & 4 & $69 . e$ & & 373 & 137 & & & 104. & & & 59.6 & 124 & & \\
\hline hybrid, M & & 1 & 918 & & 48.2 & 144 & & & 118.5 & & & 69.0 & 118 & & \\
\hline $\begin{array}{l}\text { European bison - } \\
\text { domestic cattle } \\
\text { hybrids, F }\end{array}$ & $\begin{array}{l}\text { Fest } \\
\text { Felon } \\
\text { Fellach } \\
\text { Festyn } \\
\text { Fey } \\
\text { Fez } \\
\text { Farad } \\
\text { Felly } \\
\text { Fela } \\
\text { Fama }\end{array}$ & & $\begin{array}{c}87.0 \\
90.0 \\
91.0 \\
94.0 \\
83.0 \\
93.0 \\
100.0 \\
74.0 \\
81.0 \\
81.0\end{array}$ & & $\begin{array}{l}46.4 \\
46.5 \\
50.8 \\
50.3 \\
42.6 \\
47.5 \\
52.4 \\
40.6 \\
40.5 \\
41.5\end{array}$ & $\begin{array}{l}139 \\
149 \\
127 \\
138 \\
154 \\
156 \\
145 \\
131 \\
178 \\
155\end{array}$ & & & $\begin{array}{l}109.0 \\
114.0 \\
126.0 \\
131.0 \\
107.0 \\
124.0 \\
138.0 \\
102.0 \\
109.0 \\
109.0\end{array}$ & & & $\begin{array}{l}60.9 \\
59.6 \\
73.5 \\
89.9 \\
60.6 \\
72.0 \\
78.5 \\
52.8 \\
62.6 \\
60.4\end{array}$ & $\begin{array}{l}127 \\
146 \\
118 \\
114 \\
124 \\
119 \\
123 \\
130 \\
121 \\
129\end{array}$ & 1 & \\
\hline $\begin{array}{l}\text { Domestic cattle, M } \\
\text { Domestic cattle, F } \\
\text { Watussi cattle, M } \\
\text { Watussi cattle, F }\end{array}$ & & $\begin{array}{r}2 \\
10 \\
1 \\
1\end{array}$ & $\begin{array}{l}95.2 \\
77.1 \quad 5 \\
83.5 \\
79.5\end{array}$ & 5.36 .8 & $\begin{array}{l}48.5 \\
40.2 \\
43.6 \\
41.4\end{array}$ & $\begin{array}{l}158 \\
147 \\
146 \\
148\end{array}$ & 2.1 & 1.4 & $\begin{array}{l}116.0 \\
100.6 \\
111.5 \\
102.5\end{array}$ & 1.3 & 1.3 & $\begin{array}{l}67.0 \\
62.0 \\
66.1 \\
\mathbf{5 6 . 0}\end{array}$ & $\begin{array}{l}120 \\
109 \\
115 \\
129\end{array}$ & 3.6 & 3.3 \\
\hline Bubalus bubalus L., $\mathrm{N}$ & & 1 & 82.4 & & 44.5 & 136 & & & 100.0 & & & 55.6 & 128 & & \\
\hline Zebu, F & & i & 72.0 & & 37.0 & 154 & & & 90.3 & & & 56.6 & 110 & & \\
\hline Yak. F & & 1 & 57.2 & & 31.1 & 134 & & & 752 & & & 565 & 128 & & \\
\hline
\end{tabular}

Table 12

Dimensions of trochlea of tibiotarsone (in $\mathrm{mm}$ and degrees).

\begin{tabular}{|c|c|c|c|c|c|c|c|c|c|c|c|c|c|c|c|c|c|c|c|c|c|c|c|c|c|c|c|c|c|}
\hline \multirow{3}{*}{ Group } & \multirow{3}{*}{$\mathrm{n}$} & \multicolumn{14}{|c|}{ Proximal trochlea } & \multicolumn{14}{|c|}{ Distal trochlea } \\
\hline & & \multirow[b]{2}{*}{$\overline{\mathbf{x}}$} & \multicolumn{2}{|c|}{$\begin{array}{l}\text { Length } \\
\text { (chord) }\end{array}$} & \multirow{2}{*}{\multicolumn{4}{|c|}{$\begin{array}{c}\text { Curvature } \\
\text { Angle }\end{array}$}} & \multirow{2}{*}{\multicolumn{3}{|c|}{$\begin{array}{l}\text { Length } \\
\text { (chord) }\end{array}$}} & \multirow{2}{*}{\multicolumn{4}{|c|}{ 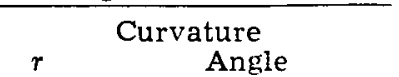 }} & \multirow{2}{*}{\multicolumn{3}{|c|}{$\begin{array}{l}\text { Length } \\
\text { (chord) }\end{array}$}} & \multirow{2}{*}{\multicolumn{4}{|c|}{$\begin{array}{c}\text { Curvature } \\
\text { Angle }\end{array}$}} & \multirow{2}{*}{\multicolumn{3}{|c|}{$\begin{array}{l}\text { Length } \\
\text { (chord) }\end{array}$}} & \multirow{2}{*}{\multicolumn{4}{|c|}{$\begin{array}{c}\text { Curvature } \\
\text { Angle }\end{array}$}} \\
\hline & & & & d) $v$ & $\stackrel{r}{\overline{\mathrm{x}}}$ & $\overline{\mathbf{x}}$ & $\begin{array}{l}\text { angle } \\
\text { ans }\end{array}$ & & $\overline{\mathrm{x}}$ & $\begin{array}{l}\text { (chor } \\
\mathrm{s}\end{array}$ & & $\stackrel{r}{\overline{\mathrm{x}}}$ & & $\begin{array}{l}\text { Angle } \\
\text { s }\end{array}$ & $\mathrm{v}$ & $\overline{\mathrm{x}}$ & $\begin{array}{l}\text { (chor } \\
\text { s }\end{array}$ & & & & & & & & & $\underset{\widetilde{\mathrm{x}}}{r}$ & & & $\mathbf{v}$ \\
\hline \multicolumn{30}{|c|}{ Males } \\
\hline 0 & 8 & 38.1 & 3.1 & 8.1 & 21.1 & 129 & 7.8 & 6.0 & 36.5 & 1.6 & 4.4 & 18.6 & 151 & 10.4 & 6.9 & 25.0 & 0.7 & 2.8 & 12.8 & 202 & 9.5 & 4.7 & 28.8 & 1.4 & 4.9 & 14.4 & 178 & 7.8 & 4.4 \\
\hline I & 5 & 42.8 & 1.8 & 4.2 & $22.7^{-}$ & 141 & 6.6 & 4.7 & 44.7 & 4.9 & 11.0 & 22.2 & 164 & 4.4 & 2.7 & 30.0 & 1.9 & 6.3 & 15.2 & 201 & 6.7 & 3.3 & 34.4 & 1.9 & 5.5 & 17.6 & 199 & 7.7 & 3.9 \\
\hline II & 16 & 50.2 & 3.3 & 6.6 & 26.4 & 143 & 9.4 & 6.6 & 48.0 & 3.3 & 6.9 & 24.2 & 167 & 11.0 & 6.6 & 34.4 & 2.2 & 6.4 & 17.4 & 198 & 8.2 & 4.1 & 38.7 & 1.7 & 4.4 & 20.3 & 215 & 10.3 & 4.8 \\
\hline III & 17 & 50.5 & 2.4 & 4.8 & 26.5 & 145 & 9.0 & 6.2 & 49.8 & 2.0 & 4.0 & 24.9 & 171 & 11.3 & 6.6 & 35.0 & 2.1 & 6.0 & 17.7 & 194 & 9.9 & 5.1 & 39.4 & 2.1 & 5.3 & 20.4 & 213 & 7.5 & 3.5 \\
\hline IV & 15 & 52.6 & 1.4 & 2.7 & 26.9 & 154 & 6.8 & 4.4 & 50.2 & 0.6 & 1.2 & 25.1 & 180 & 10.1 & 5.6 & 36.5 & 1.8 & 4.9 & 18.6 & 192 & 7.3 & 3.8 & 41.2 & 1.6 & 3.9 & 21.4 & 205 & 6.0 & 2.9 \\
\hline $\mathrm{V}$ & 13 & 52.0 & 3.7 & 7.1 & 27.2 & 149 & 8.1 & 5.4 & 50.2 & 1.8 & 3.6 & 25.1 & 180 & 8.2 & 4.6 & 36.6 & 2.0 & 5.5 & 17.9 & 190 & 7.1 & 3.7 & 40.8 & 2.0 & 4.9 & 21.2 & 212 & 6.2 & 2.9 \\
\hline G.C. & & 1.36 & & & 1.29 & 1.16 & & & 1.39 & & & 1.35 & 1.19 & & & 1.47 & & & 1.40 & 0.93 & & & 1.42 & & & 1.47 & 1.19 & & \\
\hline \multicolumn{30}{|c|}{ Females } \\
\hline 0 & 4 & 37.5 & & & 21.4 & 123 & & & 36.8 & & & 19.6 & 140 & & & 23.2 & & & 12.5 & 223 & & & 26.2 & & & 13.4 & 206 & & \\
\hline I & 1 & 42.0 & & & 27.8 & 134 & & & 40.0 & & & 20.5 & 155 & & & 29.8 & & & 15.1 & 200 & & & 35.1 & & & 18.1 & 208 & & \\
\hline II & 9 & 44.7 & 1.3 & 2.9 & 23.9 & 139 & 10.9 & 7.8 & 43.4 & 0.8 & 1.8 & 21.9 & 166 & 5.6 & 3.4 & 30.7 & 1.4 & 4.7 & 16.6 & 201 & 10.0 & 5.0 & 34.8 & 1.4 & 4.0 & 18.0 & 209 & 5.3 & 2.5 \\
\hline III & 6 & 46.8 & 2.3 & 4.9 & 24.4 & 147 & 5.8 & 3.9 & 45.4 & 1.1 & 2.4 & 22.7 & 173 & 8.1 & 4.7 & 31.8 & 1.8 & 5.7 & 15.9 & 188 & 6.5 & 3.5 & 35.4 & 2.0 & 5.6 & 18.5 & 213 & 5.7 & 2.7 \\
\hline IV & 7 & 47.8 & 3.3 & 6.9 & 25.0 & 143 & 8.4 & 5.9 & 46.4 & 2.1 & 4.5 & 23.4 & 169 & 8.1 & 4.8 & 33.4 & 2.0 & 6.0 & 16.8 & 195 & 11.3 & 5.8 & 36.3 & 0.3 & 0.9 & 19.1 & 215 & 5.7 & 2.6 \\
\hline $\mathrm{v}$ & 18 & 48.2 & 2.7 & 5.6 & 25.3 & 144 & 11.3 & 7.8 & 47.3 & 1.5 & 3.2 & 23.8 & 173 & 8.1 & 4.7 & 32.2 & 1.7 & 5.3 & 16.3 & 192 & 13.9 & 7.2 & 37.1 & 1.6 & 4.3 & 19.3 & 211 & 11.1 & 5.3 \\
\hline G.C. & & 1.28 & & & 1.18 & 1.17 & & & 1.28 & & & 1.21 & 1.24 & & & 1.39 & & & 1.30 & 0.86 & & & 1.42 & & & 1.44 & 1.02 & & \\
\hline
\end{tabular}


Table 5

Dimensions of femoral condyle (in $\mathrm{mm}$ and degrees).

\begin{tabular}{|c|c|c|c|c|c|c|c|c|c|c|c|c|c|c|c|c|c|c|c|c|c|c|c|c|c|}
\hline \multirow{4}{*}{ Species } & \multirow{4}{*}{ Sex } & \multirow{4}{*}{ Group } & \multirow{4}{*}{$\mathbf{n}$} & \multicolumn{11}{|c|}{ Lateral condyle } & \multicolumn{11}{|c|}{ Medial condyle } \\
\hline & & & & \multirow{2}{*}{\multicolumn{3}{|c|}{ Length (chord) }} & \multirow{2}{*}{\multicolumn{3}{|c|}{ Width }} & \multicolumn{4}{|c|}{ Curvature } & \multirow{3}{*}{$\begin{array}{l}\text { Length: } \\
\text { width } \\
\text { ratio }\end{array}$} & \multirow{2}{*}{\multicolumn{3}{|c|}{ Length (chord) }} & \multirow{2}{*}{\multicolumn{3}{|c|}{ Width }} & \multicolumn{4}{|c|}{ Curvature } & \multirow{3}{*}{$\begin{array}{l}\text { Length: } \\
\text { width } \\
\text { ratio }\end{array}$} \\
\hline & & & & & & & & & & $\mathbf{I}$ & & ngle & & & & & & & & & $\cdot \mathbf{r}$ & $\bar{x}$ & $\begin{array}{c}\text { ngle } \\
s\end{array}$ & $\mathrm{y}$ & \\
\hline & & & & $\overline{\mathbf{x}}$ & $\mathbf{s}$ & $\mathrm{v}$ & $\overline{\mathrm{x}}$ & $\mathbf{s}$ & $\mathbf{v}$ & $\bar{x}$ & $\mathbf{x}$ & $\mathbf{s}$ & $\mathrm{v}$ & & $x$ & 8 & $v$ & $\mathbf{x}$ & -3 & $v$ & & $x$ & 8 & 8 & \\
\hline \multirow[t]{2}{*}{ European bison } & M & $\begin{array}{r}0 \\
\text { I } \\
\text { II } \\
\text { III } \\
\text { IV } \\
\text { V } \\
\text { G.C. }\end{array}$ & $\begin{array}{r}8 \\
5 \\
16 \\
17 \\
15 \\
13\end{array}$ & $\begin{array}{l}36.8 \\
53.5 \\
66.0 \\
69.7 \\
70.8 \\
71.8 \\
1.95\end{array}$ & $\begin{array}{l}2.2 \\
3.2 \\
4.8 \\
2.6 \\
1.0 \\
3.9\end{array}$ & $\begin{array}{l}6.0 \\
6.0 \\
7.3 \\
3.7 \\
1.4 \\
5.4\end{array}$ & $\begin{array}{l}21.0 \\
32.2 \\
41.0 \\
46.7 \\
48.8 \\
49.6 \\
2.36\end{array}$ & $\begin{array}{l}2.0 \\
3.6 \\
3.0 \\
2.4 \\
1.0 \\
3.7\end{array}$ & $\begin{array}{r}9.5 \\
11.2 \\
7.3 \\
5.1 \\
2.0 \\
7.4\end{array}$ & $\begin{array}{l}19.0 \\
27.5 \\
33.2 \\
35.1 \\
35.9 \\
36.2 \\
1.88\end{array}$ & $\begin{array}{r}151 \\
153 \\
167 \\
167 \\
161 \\
164 \\
1.09\end{array}$ & $\begin{array}{r}18.1 \\
21.2 \\
10.1 \\
9.5 \\
4.8 \\
7.4\end{array}$ & $\begin{array}{r}12.0 \\
13.8 \\
6.0 \\
5.7 \\
3.0 \\
4.5\end{array}$ & $\begin{array}{l}1: 0.75 \\
1: 0.66 \\
1: 0.61 \\
1: 0.49 \\
1: 0.45 \\
1: 0.45\end{array}$ & $\begin{array}{l}37.6 \\
48.0 \\
64.2 \\
69.9 \\
71.4 \\
72.1 \\
1.92\end{array}$ & $\begin{array}{l}4.2 \\
6.6 \\
3.5 \\
3.0 \\
1.4 \\
1.7\end{array}$ & $\begin{array}{r}11.2 \\
13.8 \\
5.4 \\
4.3 \\
2.0 \\
2.4\end{array}$ & $\begin{array}{l}21.1 \\
32.0 \\
43.3 \\
47.4 \\
49.4 \\
50.6 \\
2.40\end{array}$ & $\begin{array}{l}3.1 \\
4.4 \\
3.2 \\
2.2 \\
1.7 \\
1.4\end{array}$ & $\begin{array}{r}14.7 \\
13.8 \\
7.4 \\
4.6 \\
3.4 \\
2.8\end{array}$ & $\begin{array}{l}19.0 \\
24.0 \\
32.1 \\
35.0 \\
35.7 \\
36.1 \\
1.90\end{array}$ & $\begin{array}{l}165 \\
175 \\
182 \\
179 \\
177 \\
177 \\
1.07\end{array}$ & $\begin{array}{l}4.6 \\
6.2 \\
5.9 \\
8.1 \\
3.2 \\
8.9\end{array}$ & $\begin{array}{l}2.8 \\
3.5 \\
3.2 \\
4.5 \\
1.8 \\
5.0\end{array}$ & $\begin{array}{l}1: 0.78 \\
1: 0.50 \\
1: 0.48 \\
1: 0.47 \\
1: 0.44 \\
1: 0.42\end{array}$ \\
\hline & F & $\begin{array}{r}0 \\
\text { I } \\
\text { II } \\
\text { III } \\
\text { IV } \\
\text { V } \\
\text { G.C. }\end{array}$ & $\begin{array}{r}4 \\
1 \\
9 \\
6 \\
7 \\
18\end{array}$ & $\begin{array}{l}35.3 \\
50.0 \\
60.5 \\
64.0 \\
63.7 \\
64.6 \\
1.83\end{array}$ & $\begin{array}{l}2.8 \\
2.2 \\
2.0 \\
3.0\end{array}$ & $\begin{array}{l}4.6 \\
3.4 \\
3.1 \\
4.6\end{array}$ & $\begin{array}{l}20.8 \\
29.0 \\
38.5 \\
41.2 \\
42.8 \\
43.4 \\
2.09\end{array}$ & $\begin{array}{l}\dot{3} .6 \\
2.0 \\
2.0 \\
2.6\end{array}$ & $\begin{array}{l}9.4 \\
4.8 \\
4.7 \\
6.0\end{array}$ & $\begin{array}{l}18.7 \\
25.3 \\
30.4 \\
32.7 \\
31.9 \\
32.5 \\
1.74\end{array}$ & $\begin{array}{c}150 \\
162 \\
168 \\
156 \\
172 \\
162 \\
1.08\end{array}$ & $\begin{array}{r}15.9 \\
6.2 \\
6.4 \\
2.6\end{array}$ & $\begin{array}{l}9.5 \\
4.0 \\
3.7 \\
1.6\end{array}$ & $\begin{array}{l}1: 0.78 \\
1: 0.70 \\
1: 0.57 \\
1: 0.55 \\
1: 0.49 \\
1: 0.49\end{array}$ & $\begin{array}{l}34.3 \\
46.0 \\
56.8 \\
63.0 \\
63.3 \\
64.0 \\
1.87\end{array}$ & $\begin{array}{l}1.7 \\
1.4 \\
2.4 \\
6.7\end{array}$ & $\begin{array}{r}3.0 \\
2.2 \\
3.8 \\
10.5\end{array}$ & $\begin{array}{l}20.1 \\
29.0 \\
38.2 \\
41.8 \\
43.0 \\
43.9 \\
2.18\end{array}$ & $\begin{array}{l}2.8 \\
2.2 \\
2.2 \\
2.2\end{array}$ & $\begin{array}{l}7.3 \\
5.3 \\
5.1 \\
5.0\end{array}$ & $\begin{array}{l}17.3 \\
23.0 \\
28.4 \\
31.5 \\
32.2 \\
31.8 \\
1.86\end{array}$ & $\begin{array}{l}166 \\
174 \\
181 \\
179 \\
176 \\
181 \\
1.09\end{array}$ & $\begin{array}{l}4.7 \\
4.0 \\
4.4 \\
6.7\end{array}$ & $\begin{array}{l}2.6 \\
2.2 \\
2.5 \\
3.7\end{array}$ & $\begin{array}{l}1: 0.63 \\
1: 0.59 \\
1: 0.49 \\
1: 0.51 \\
1: 0.47 \\
1: 0.46\end{array}$ \\
\hline $\begin{array}{l}\text { Bison bison } \\
\text { B. bonasus - }\end{array}$ & $F$ & & 4 & 58.2 & & & 38.6 & & & 29.3 & 168 & & & $1: 0.51$ & 56.9 & & & 40.3 & & & 28.5 & 173 & & & $1: 0.41$ \\
\hline B. bison hybrid & $\mathbf{M}$ & & 1 & 75.1 & & & 58.2 & & & 38.6 & 153 & & & $1: 0.29$ & 69.2 & & & 55.0 & & & 34.7 & 172 & & & $1: 0.23$ \\
\hline Domestic cattle & $\stackrel{\mathrm{M}}{\mathrm{F}}$ & & $\begin{array}{c}2 \\
10\end{array}$ & $\begin{array}{l}79.2 \\
63.9\end{array}$ & 5.9 & 9.2 & $\begin{array}{l}58.5 \\
43.8\end{array}$ & 1.6 & 3.6 & $\begin{array}{l}39.9 \\
32.2\end{array}$ & $\begin{array}{c}166 \\
166\end{array}$ & 13.1 & 7.9 & $\begin{array}{l}1: 0.35 \\
1: 0.46\end{array}$ & $\begin{array}{l}76.4 \\
62.2\end{array}$ & 3.8 & 6.1 & $\begin{array}{l}55.6 \\
40.7\end{array}$ & 3.2 & 7.9 & $\begin{array}{l}38.3 \\
31.1\end{array}$ & $\begin{array}{l}186 \\
176\end{array}$ & 4.8 & 2.7 & $\begin{array}{l}1: 0.37 \\
1: 0.53\end{array}$ \\
\hline Watussi cattle & $\frac{\mathrm{M}}{\mathrm{F}}$ & & $\begin{array}{l}1 \\
1\end{array}$ & $\begin{array}{l}71.7 \\
59.8\end{array}$ & & & $\begin{array}{l}59.5 \\
48.0\end{array}$ & & & $\begin{array}{l}36.3 \\
29.9\end{array}$ & $\begin{array}{l}162 \\
184\end{array}$ & & & $\begin{array}{l}1: 0.21 \\
1: 0.20\end{array}$ & $\begin{array}{l}69.0 \\
61.0\end{array}$ & & & $\begin{array}{l}48.5 \\
48.3\end{array}$ & & & $\begin{array}{l}35.7 \\
30.8\end{array}$ & $\begin{array}{l}150 \\
163\end{array}$ & & & $\begin{array}{l}1: 0.42 \\
1: 0.26\end{array}$ \\
\hline Bubalus bubalus & M & & 1 & 66.8 & & & 50.5 & & & 33.9 & 161 & & & $1: 0.32$ & 66.2 & & & 43.5 & & & 33.1 & 185 & & & $1: 0.52$ \\
\hline Zebu & $\mathbf{F}$ & & 1 & 55.9 & & & 43.8 & & & 27.9 & 180 & & & $1: 0.28$ & 54.5 & & & 37.6 & & & 27.3 & 174 & & & $1: 0.45$ \\
\hline
\end{tabular}

Table 7

Linear dimensions and volume of menisci (in $\mathrm{mm}$ and $\mathrm{cu} . \mathrm{cm}$ ).

\begin{tabular}{|c|c|c|c|c|c|c|c|c|c|c|c|c|c|c|c|c|c|c|c|c|c|c|c|c|c|c|}
\hline \multirow{3}{*}{ Sex } & \multirow{3}{*}{ Group } & \multirow{3}{*}{$\mathrm{n}$} & \multicolumn{12}{|c|}{ Lateral meniscus } & \multicolumn{12}{|c|}{ Medial meniscus } \\
\hline & & & \multicolumn{3}{|c|}{ Length } & \multicolumn{3}{|c|}{ Width } & \multicolumn{3}{|c|}{ Thickness } & \multicolumn{3}{|c|}{ Volume } & \multicolumn{3}{|c|}{ Length } & \multicolumn{3}{|c|}{ Width } & \multicolumn{3}{|c|}{ Thickness } & \multicolumn{3}{|c|}{ Volume } \\
\hline & & & $\overline{\mathbf{x}}$ & $\mathbf{s}$ & $\mathrm{v}$ & $\overline{\mathbf{x}}$ & $\mathbf{s}$ & $\mathbf{v}$ & $\overline{\mathbf{x}}$ & $\mathbf{s}$ & $\mathrm{v}$ & $\overline{\mathbf{x}}$ & $\mathbf{s}$ & $\mathrm{v}$ & $\overline{\mathbf{x}}$ & $\mathbf{s}$ & $\mathrm{v}$ & $\bar{x}$ & $\mathrm{~s}$ & $\mathrm{v}$ & $\overline{\mathbf{x}}$ & s & $\mathrm{v}$ & $\overline{\mathbf{x}}$ & $\mathbf{s}$ & $v$ \\
\hline \multicolumn{27}{|c|}{ European bison } \\
\hline M & $\begin{array}{l}\text { O } \\
\text { I } \\
\text { II } \\
\text { III } \\
\text { IV } \\
\text { V } \\
\text { G. C. }\end{array}$ & $\begin{array}{r}8 \\
5 \\
11 \\
8 \\
8 \\
7\end{array}$ & $\begin{array}{l}41.3 \\
43.5 \\
60.3 \\
61.4 \\
65.0 \\
64.0 \\
1.54\end{array}$ & $\begin{array}{l}2.6 \\
2.3 \\
1.0 \\
2.6 \\
1.4 \\
1.0\end{array}$ & $\begin{array}{l}6.3 \\
6.3 \\
1.6 \\
4.2 \\
2.3 \\
1.6\end{array}$ & $\begin{array}{l}26.9 \\
28.0 \\
41.3 \\
42.8 \\
43.4 \\
44.4 \\
1.65\end{array}$ & $\begin{array}{l}0.6 \\
1.5 \\
1.0 \\
2.0 \\
2.2 \\
2.2\end{array}$ & $\begin{array}{l}2.2 \\
5.4 \\
2.4 \\
4.8 \\
5.1 \\
5.0\end{array}$ & $\begin{array}{l}13.9 \\
13.9 \\
18.0 \\
19.3 \\
20.0 \\
20.2 \\
1.45\end{array}$ & $\begin{array}{l}1.3 \\
1.6 \\
1.4 \\
2.4 \\
0.6 \\
0.6\end{array}$ & $\begin{array}{r}9.4 \\
11.5 \\
7.8 \\
12.4 \\
3.0 \\
3.0\end{array}$ & $\begin{array}{r}5.0 \\
8.3 \\
20.0 \\
22.2 \\
24.8 \\
28.1 \\
5.62\end{array}$ & $\begin{array}{l}1.7 \\
1.2 \\
5.0 \\
2.2 \\
3.0 \\
2.0\end{array}$ & $\begin{array}{r}34.0 \\
14.4 \\
25.0 \\
9.9 \\
12.1 \\
7.1\end{array}$ & $\begin{array}{l}38.7 \\
46.1 \\
63.5 \\
64.9 \\
67.0 \\
70.0 \\
1.81\end{array}$ & $\begin{array}{l}2.6 \\
3.0 \\
5.0 \\
1.4 \\
2.2 \\
5.6\end{array}$ & $\begin{array}{l}6.7 \\
6.9 \\
7.9 \\
2.2 \\
3.3 \\
8.0\end{array}$ & $\begin{array}{l}27.8 \\
32.0 \\
45.3 \\
46.7 \\
51.0 \\
51.0 \\
1.83\end{array}$ & $\begin{array}{l}0.8 \\
0.5 \\
0.8 \\
0.1 \\
0.5 \\
1.8\end{array}$ & $\begin{array}{l}2.9 \\
1.6 \\
1.8 \\
0.2 \\
1.0 \\
3.5\end{array}$ & $\begin{array}{r}9.0 \\
7.8 \\
15.3 \\
16.2 \\
15.7 \\
15.8 \\
1.76\end{array}$ & $\begin{array}{l}0.7 \\
0.8 \\
1.8 \\
0.8 \\
1.0 \\
1.2\end{array}$ & $\begin{array}{r}7.8 \\
10.2 \\
11.8 \\
4.9 \\
6.4 \\
7.6\end{array}$ & $\begin{array}{r}4.3 \\
7.0 \\
19.7 \\
20.6 \\
23.8 \\
28.1 \\
6.55\end{array}$ & $\begin{array}{l}0.3 \\
3.0 \\
4.8 \\
4.1 \\
3.9 \\
2.2\end{array}$ & $\begin{array}{r}7.0 \\
4.3 \\
24.4 \\
19.9 \\
16.4 \\
7.8\end{array}$ \\
\hline $\mathrm{F}$ & $\begin{array}{c}0 \\
\text { I } \\
\text { II } \\
\text { III } \\
\text { IV } \\
\text { V } \\
\text { G.C. }\end{array}$ & $\begin{array}{l}4 \\
1 \\
6 \\
1 \\
3 \\
9\end{array}$ & $\begin{array}{l}37.5 \\
43.0 \\
51.8 \\
51.0 \\
54.7 \\
59.7 \\
1.59\end{array}$ & 1.4 & 2.3 & $\begin{array}{l}23.2 \\
28.0 \\
346 \\
370 \\
37.3 \\
41.5 \\
1.79\end{array}$ & 2.0 & 4.8 & $\begin{array}{l}11.9 \\
11.2 \\
16.0 \\
16.8 \\
17.8 \\
18.3 \\
1.64\end{array}$ & 1.0 & $\begin{array}{l}7.5 \\
5.5\end{array}$ & $\begin{array}{l}4.0 \\
8.0 \\
11.2 \\
13.0 \\
14.0 \\
18.6 \\
4.65\end{array}$ & 1.2 & 15.2 & $\begin{array}{l}36.2 \\
46.0 \\
50.8 \\
55.0 \\
58.0 \\
59.7 \\
1.65\end{array}$ & 1.8 & 3.0 & $\begin{array}{l}25.5 \\
34.5 \\
36.2 \\
38.5 \\
41.0 \\
44.3 \\
1.74\end{array}$ & 2.8 & 2.3 & $\begin{array}{r}9.9 \\
9.3 \\
11.5 \\
12.3 \\
11.3 \\
13.6 \\
1.37\end{array}$ & 1.0 & 7.4 & $\begin{array}{r}3.2 \\
7.0 \\
10.0 \\
11.5 \\
13.3 \\
15.5 \\
4.84\end{array}$ & 1.6 & 11.0 \\
\hline
\end{tabular}

Acta theriol., 21, 4, wklejka str. $64 / 65$. 